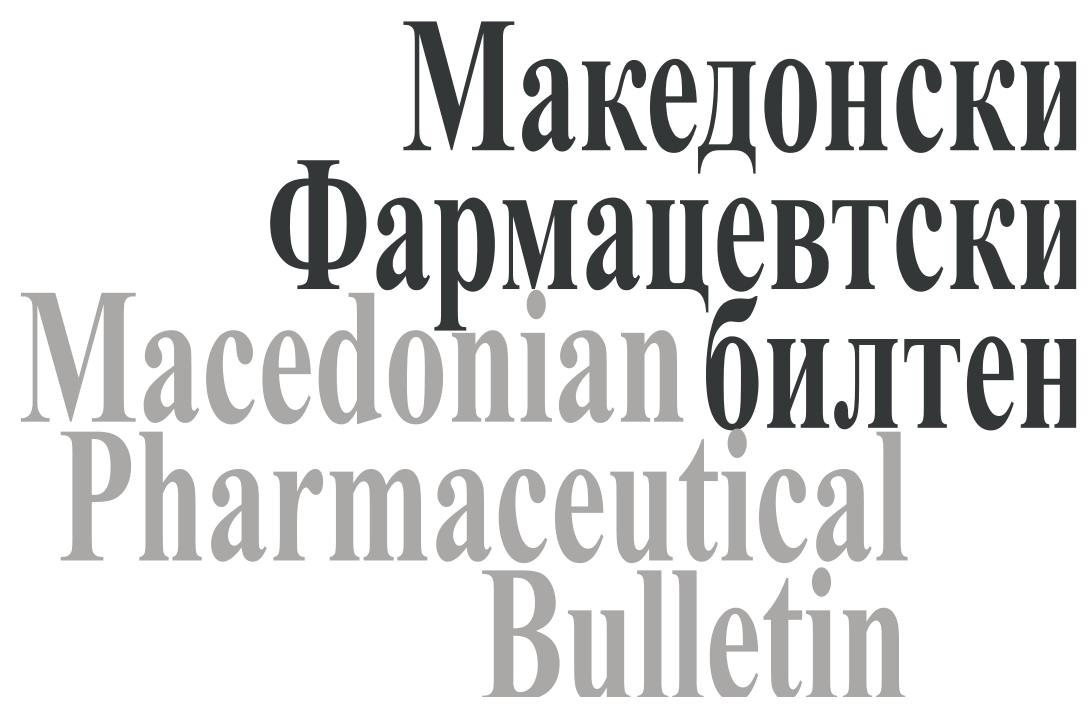

волумен $\mathbf{5 8}(1,2) 2012$ / volume $\mathbf{5 8}(1,2) 2012$

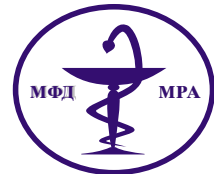

Македонско фармацевтско друштво, ул. Маршал Тито 13б/8, Скопје, Македонија Macedonian Pharmaceutical Society, Marshal Tito 13b/8, Skopje Macedonia 


\title{
Therapeutic strategies in the treatment of periodontitis
}

\author{
Liljana Bogdanovska ${ }^{1}$, Silvana Kukeska ${ }^{2}$, Mirjana Popovska ${ }^{3}$, Rumenka Petkovska ${ }^{1}$, \\ Katerina Goracinova ${ }^{2 *}$
}

\author{
${ }^{1}$ Institute of Applied Chemistry and Pharmaceutical Analysis, Faculty of Pharmacy, ,Ss Cyril and Methodius “University, \\ Vodnjanska 17, Skopje, Macedonia \\ ${ }^{2}$ Institute of Pharmaceutical Technology, Faculty of Pharmacy, ,Ss Cyril and Methodius" University, Vodnjanska 17, \\ Skopje, Macedonia \\ ${ }^{3}$ Clinic of Oral pathology and Periodontology, Faculty of Dentistry, ,, Ss Cyril and Methodius “ University, Vodnjanska 16, \\ Skopje, Macedonia
}

Received: February 2012; Accepted: April 2012

\begin{abstract}
Periodontitis is a chronic inflammatory process which affects the tooth - supporting structures of the teeth. The disease is initiated by subgingival periopathogenic bacteria in susceptible periodontal sites. The host immune response towards periodontal pathogens helps to sustain periodontal disease and eventual alveolar bone loss. Although scaling and root planing is the standard treatment modality for periodontitis, it suffers from several drawbacks such as the inability to reach the base of deep pockets and doesn't arrest migration of periodontal pathogens from other sites in the oral cavity. In order to overcome the limitations of scaling and root planning, adjunctive chemotherapeutics and host modulatory agents to the treatment are used. These therapeutic agents show substantial beneficial effects when compared to scaling and root planning alone. This review will cover an update on chemotherapeutic and past and future host immune modulatory agents used adjunctively to treat and manage periodontal diseases.
\end{abstract}

Keywords: periodontitis, periodontal therapy, antibiotics, antiseptics, host modulatory agents

\section{Introduction}

Periodontal disease is a chronic infection of the periodontium that affects the soft and mineralized tissues surrounding the teeth (Hajishengallis and Lambris, 2012). Periodontal diseases include conditions such as chronic periodontitis, aggressive periodontitis, systemic disease-associated periodontitis and necrotizing periodontitis (Schwach-Abdellaoui et al., 2000). Together with dental caries, periodontal disease is the most common chronic disease in the dental fields being severe enough to lead to tooth loss in 10 - 15\% of adults (Kantarci and Van Dyke, 2005). Recent studies have shown that several systemic illnesses such as rheumatoid arthritis and cardiovascular dis-

\footnotetext{
* kago@ff.ukim.edu.mk
}

ease might be also linked to the presence of periodontitis (Kinane and Lowe, 2000).

The clinical signs of periodontitis include inflammatory changes in gingival tissues, bleeding upon probing, attachment loss and periodontal pocket formation. Periodontal pockets provide nutritious and anaerobic environment for the so called periopathogenic bacteria colonization and multiplication (Schwach-Abdellaoui et al., 2000). Among the 700 bacterial taxa that have been identified to inhabit periodontal pockets, only a small group of 10 to 15 species has been identified as being significantly associated with periodontitis (Slots, 2002). The bacterial microflora found in periodontits is complex; moreover studies have shown that the various clinical forms of periodontitis are associated with different periopathogenic bacteria (Haffajee and Socransky, 1994). The most important periodontal pathogens are Gram negative, facultative anaerobic species such as Actinobacillus actinomycetemcomitans, Porphyromo- 
nas gingivalis, Dialister pneumosintes, Bacterioides forsythus and Treponema denticola (Slots, 2002; Jain et al., 2008).

Scientific research aimed at elucidation of etiopathogenesis of periodontal disease implies that periodontal disease is an inflammatory condition caused by the accumulation of periopathogenic bacteria on tooth surfaces in the form of oral biofilms (Bostanci et al., 2011). The subgingival bacterial colonization and biofilm formation provokes chronic inflammation of soft tissues, degradation of collagen fibres supporting the tooth to the gingival and alveolar bone as well as resorbtion of the alveolar bone itself (Krayer et al., 2010).

Although bacteria are the primary etiological cause of periodontal disease, the expression of bacterial pathogenic factors alone is probably not sufficient to cause periodontitis. Immunopathogenesis of periodontitis, similar to inflammatory bowel disease is hypothetised to involve immune-inflammatory pathways in both diseases. It has been found that individual response is affected by genetic signaling pathways that influence the expression of inflammatory mediators in response to bacterial lypopolysaccharides (Goracinova et al., 2012).

As discussed by Brandztaeg P., progressive immunopathology of chronic inflammatory mucosal diseases in general appears to be a result of perturbation of a tightly controlled cytokine network with abnormal crosstalk between several cell types (Brandztaeg, 2001).

Tissue destruction is a result of the mobilization of host tissues via activation of monocytes, fibroblasts and other host cells. The activation of these host cellular elements by bacterial factors, in particular bacterial lipopolysacharide (LPS), is thought to stimulate both catabolic cytokines (TNF- $\alpha$, IL-1, IL-6) and inflammatory mediators including arachidonic acid metabolites such as prostaglandin $\mathrm{E}_{2}\left(\mathrm{PGE}_{2}\right)$. These cytokines and inflammatory mediators in turn promote the release of tissue-derived enzymes, matrix-matalloproteinases, which are destructive to the extracellular matrix and bone. Also, evidence indicates that periodontal disease is an autoimmune disorder triggered by infectious organisms and an abnormal response to collagen in the periodontium. Current research in periodontal pathobiology has identified a novel cytokine, IL-17 which is thought to play an important role in triggering autoimmune responses (Suresh, 2011).

The treatment of periodontal disease as an infection has been well studied through the years. This so called antimicrobial approach includes local or systemic delivery of antimicrobial agents (local/ systemic antibiotics) or topical antiseptics. These treatment strategies however may be insuficient to block or inhibit the host mediated tissue destruction of the periodontium.

The current concept in periodontal treatment emphasizes on host - microbial interactions to understand the disease process, as well as to develop novel therapeutic strategies known as host modulatory therapies (Kray- er et al., 2010). The development of effective host-modulatory pharmacotherapies that specifically target the host response mechanisms and the introduction of such therapies as an adjunct to traditional antimicrobial interventions might represent a new, integrated approach in the management of periodontal disease. This rewiev will cover current antimicrobial therapy as well as the possibilities for future developments in the treatment of periodontal disease.

\section{Antimicrobial approach in the treatment of periodontitis}

\section{Systemic antibiotics}

The traditional antimicrobial treatment of periodontitis consists mainly of mechanical debridement (scaling and root planning, SRP) of root surfaces in order to disrupt the bacterial biofilm (Herrera et al., 2012). This antimicrobial procedure usually stops the progression of attachment loss but in patients who are infected by invasive periopathogenic bacteria (Actinobacillus actinomycetemcomitans, Porphyromonas gingivalis or Prevotella intermedia) it is impossible to gain therapeutic benefit using mechanical debridgement only.

Systemic antibiotics are of particular benefit in combating severe forms of periodontal disease such as aggressive periodontitis and necrotizing periodontitis (Slots, 2002). Prime candidates for systemic antibiotic therapy are patients who exhibit continuous periodontal breakdown and alveolar bone loss despite mechanical debridement.

Systemic antibiotics enter periodontal tissues and the periodontal pockets via serum and can affect organisms outside the reach of cleaning instruments or topical anti-infective chemotherapeutics. They have the advantages of conventional and acceptable delivery for the patients (Krayer et al., 2010). Systemic antibiotic therapy has also the potential to suppress periodontal pathogens residing on the tongue or other oral surfaces, thereby delaying subgingival recolonisation of pathogens (Slots, 2002).

The administration of systemic antibiotics in the periodontal treatment has been well studied and documented. Early approaches to systemic antibiotics in periodontal treatment included mainly single drug therapies. Systemic antibiotic monotherapies include administration of amoxicillin, metronidazole, tetracyclines (doxycycline), clindamycin, azitromycin, claritromycin and ciprofloxacin as an adjunct to mechanical debridement. Since periodontal lesions often harbor a mixture of pathogenic bacteria, today's approach recommends, where necessary, usage of combinations consisting of two antibiotics (Slots, 2002; Slots \& Ting, 2002).

Current literature supports the clinical benefit from the use of azithromycin as a systemic antibiotic in combination with mechanical mechanical debridgement (Hirsch et al., 2011). The addition of azithromycin in periodontal therapy reduces the red complex bacteria and gives rapid wound 
healing (Krayer et al, 2010; Dastoor et al., 2007). Some evidence exists to support the use of azithromycin in the treatment of periodontitis because of its anti-inflammatory effects on the gingiva. The fact that systemic administration of azitromycin produces relatively high and sustained levels in gingival crevicular fluid (GCF) could provide a rationale for future clinical evaluation of its benefit in the treatment of periodontitis (Lai et al., 2011).

Claritromycin, a closely related macrolide to azythromycin, is actively transported and concentrated inside oral epithelial cells and gingival fibroblasts reaching higher concentrations in gingival tissue when compared with those obtained in serum (Lai et al., 2011; Chou and Walters, 2008; Burell and Walters, 2008). Current findings suggest that this antibiotic could be of particular value in periodontitis assotiated with infections caused by A. actinomycetemcomitans.

Clindamycin (lincosamide) inhibits the bacterial protein synthesis by binding to the $50 \mathrm{~S}$ ribosomal unit. Depending on the local drug concentration and the susceptibility of bacteria, clindamycin has either bacteriostatic or bactericidal effect. Due to its potential to cause serious adverse effects, such as pseudomembraneous colitis, this therapy should be considered only in patients suffering from aggressive and/or refractory periodontitis (Horz and Conrads, 2007).

Other systemic monotherapies consist of administration of fluoroquinolones which are bactericidal and interfere with bacteria DNA packaging, transcription and replication. Older quinolones such as ciprofloxacin are only recommended as part of the combined therapies. Newer quinolones such as moxifloxacin and levofloxacin have an extended spectrum of activity and serve as "reserve antibiotics" in intensive care patients. Their regular prescription even in the cases of aggressive periodontits cannot be recommended (Horz and Conrads, 2007).

Valuable combination therapies include metronidazole-amoxicillin (250-375 mg of each 3 x daily for 8 days) for A. actinomycetemcomitans or metronidazole-ciproflox- acin (500 mg of each $2 \mathrm{x}$ daily for 8 days) for mixed anaerobic infections (Slots and Ting, 2002).

The combination of metronidazole-amoxicillin is known as the "van Winkelhoff combination". In conjunction with scaling and root planning (SRP), it provides a substantial benefit than SRP alone. In addition, the data from Slots and Ting suggest that this combination is suitable choice for approximately $70 \%$ of severe periodontitis patients (Slots and Ting, 2002).

The combination of metronidazole-ciprofloxacin has been suggested as an adjunctive therapy for periodontal infections when enteric rods, pseudomonas or A. actinomycetemcomitans are present or in the cases of penicillin allergy. Another combination that can be of use is amoxicillin + clavulanic acid/metronidazole, however, no real advantage over metronidazole-amoxicillin is observed in the majority of periodontal cases (Horz and Conrads, 2007). Commonly used antibiotics and their dosage in adult periodontitis are shown in Table 1.

Research data have shown that antibiotics are detectable in GCF in the therapeutic range for treatment efficacy. However, disadvantages include inadequate drug concentration in the periodontal pocket, rapid decline of the plasma antibiotic concentration to subtherapeutic levels, high peak plasma concentration that might be associated with side effects. Another frequently overlooked factor is that systemic antibiotics do not penetrate the subgingival biofilm to kill bacteria.

Concerns are raised regarding periopathogenic bacterial resistance with systemic antibiotic therapy. Therefore, systemic antibiotic therapy should be administered only after proper patient evaluation. Systemic antibiotic therapy that is properly selected to patients with aggressive periodontitis can give rise to a striking clinical outcome. In patients with chronic periodontitis, the utility of systemic antibiotics is not as clear. Patients with gingivitis or chronic periodontitis who respond well to conventional scaling and root planning may not benefit significantly from additional antibiotic therapy.

Table 1. Antibiotics used frequently in the treatment of periodontal diseases

\begin{tabular}{ll}
\hline \hline \multicolumn{1}{c}{ Antibiotic } & \multicolumn{1}{c}{ Dosage in adult periodontitis } \\
\hline Metronidazole & $500 \mathrm{mg}$ three times daily \\
Clindamycin & $150 \mathrm{mg}$ three times daily for eight days \\
Penicillins (amoxicillin) & $250-500 \mathrm{mg}$ three times daily \\
Tetracyclines (doxycycline) & $200 \mathrm{mg}$ initially, $100 \mathrm{mg}$ for seven days \\
Azithromycin & $250-500 \mathrm{mg}$ for three days \\
Claritromycin & $500 \mathrm{mg} 2 \mathrm{x}$ daily for three days \\
Fluoroquinolones (ciprofloxacin) & $500 \mathrm{mg}$ twice a day for eight days \\
Amoxicillin/Metronidazole & $250-375 \mathrm{mg}$ of each $3 \times$ daily for 8 days \\
Metronidazole/Ciprofloxacin & $250 \mathrm{mg}$ of each $2 \times$ daily for 8 days \\
Amoxicillin + clavulanic acid/metronidazole & $250 \mathrm{mg} 3$ x daily for 8 days \\
\hline
\end{tabular}

Макед. фарм. билт., 58 (1, 2) 3 - 14 (2012) 


\section{Local antimicrobials}

Advances in understanding the etiology and pathogenesis of periodontits have led to the development of effective pharmacological interventions. In this regard, safe and efficacious medications can be delivered into periodontal pockets to suppress or eradicate the periopatogenic bacteria or modulate the immune response, thereby limiting periodontal tissue destruction.

Local delivery formulations are of particular use in cases where systemic drug application seems inappropriate, such as localised periodontitis (Horz and Conrads, 2007). They are highly desirable due to lower incidence of undesirable side effects, improved efficacy and enhanced patient compliance.

Drug delivery devices intended for the periodontal pockets can be made as fibers, strips, films, injectable gels, micro/nanoparticulate systems or vesicular systems (Schwach-Abdellaoui et al., 2000; Jain et al., 2008). Tetracycline- $\mathrm{HCl}$, doxycycline, minocycline, metronidazole, chlohexidine and ofloxacin are among the antimicrobials that have been used in the formulation of local delivery devices for direct pocket placement in the treatment of periodontitis. Some of the commercially available local delivery systems for periodontal treatment and their characteristics are given in Table 2.

Although many publications on the local delivery concept have appeared in periodontal literature since 1970s, there are surprisingly few studies that demonstrate clinical efficacy using controlled release local delivery systems in periodontitis patients. Despite the reported clinical success, currently available controlled release formulations suffer from several disadvantages: the requirement for mechanical binding of the drug delivery system to a tooth surface to prevent removal of the system from the periodontal pocket as a result of the positive flow of GCF from the pocket into the oral cavity; the requirement for removal of toothbound, non-biodegradable drug delivery systems at the termination of the treatment, poor retention of oil-based delivery systems within the aqueous environment of the periodontal pocket and potential deleterious effects of plasticizers leached from solid polymeric drug delivery systems on the periodontal tissues. In conclusion, the publications dealing with efficacy studies suggest that the controlled delivery devices are useful adjunct to conventional surgical and non-surgical treatment but are no substitute for these measures. Even though scientific evidence would support the adjunctive use of local antimicrobials in these clinical indications, there are some important issues that might limit their effectiveness: clinical management properties, as some products are difficult to handle and require extensive dental office time; pharmacokinetic profiles, as some products have short-term duration in the pocket and are cleansed by the GCF, which requires a high number of chair visits to sustain their antibacterial activity (Herrera et al., 2012).

\section{Topical antiseptics}

Topical antiseptics represent a group of agents which applied to living tissues are able to prevent or arrest the growth or action of microorganisms. Antiseptics possess broader activity spectrum than antibiotics and in contrast to antibiotics, often have multiple intracellular targets which reduce likelihood of resistance development (Slots, 2002).

Table 2. Commercially available local delivery systems for periodontal treatment

\begin{tabular}{|c|c|c|c|c|}
\hline $\begin{array}{c}\text { Commercial } \\
\text { product }\end{array}$ & $\begin{array}{c}\text { Local delivery } \\
\text { system }\end{array}$ & Therapeutic compound & Application & Advantages \\
\hline Actisite $^{\mathrm{TM}}$ & $\begin{array}{l}\text { Nonabsorbable } \\
\text { Fiber }\end{array}$ & $25 \%$ tetracycline $\mathrm{HCl}$ & $\begin{array}{c}1 \text { application } \\
7 \text { day treatment } \\
\text { Chairside }\end{array}$ & $\begin{array}{c}\text { Bactericidal } \\
\text { High levels of tetracycline } \\
\text { in GCF }\end{array}$ \\
\hline Atridox $^{\mathrm{TM}}$ & Gel & $10 \%$ doxycycline hyclate & $\begin{array}{c}1 \text { application } \\
7 \text { day treatment } \\
\text { Chairside }\end{array}$ & $\begin{array}{c}\text { Forms solid implant } \\
\text { Biodegradable } \\
\text { bactericidal }\end{array}$ \\
\hline $\operatorname{Arestin}^{\mathrm{TM}}$ & Microspheres & 1mg minocycline $\mathrm{HCl}$ & $\begin{array}{c}1 \text { application } \\
14 \text { day treatment } \\
\text { Chairside }\end{array}$ & $\begin{array}{c}\text { Bioadhesive } \\
\text { Biodegradable } \\
\text { Bactericidal }\end{array}$ \\
\hline $\begin{array}{c}\text { Periocline } \\
\text { Dentomycin }^{\circledR}\end{array}$ & Gel & $2 \%$ minocycline $\mathrm{HCl}$ & $\begin{array}{c}1 \text { application } \\
14 \text { day treatment } \\
\text { Chairside }\end{array}$ & $\begin{array}{l}\text { Bioadhesive } \\
\text { Biodegradable } \\
\text { bactericidal }\end{array}$ \\
\hline Periochip $^{\circledR}$ & Thin, solid, chip & $\begin{array}{c}2.5 \mathrm{mg} \text { chlorhexidine } \\
\text { digluconate }\end{array}$ & $\begin{array}{c}1 \text { application } \\
7 \text { day treatment } \\
\text { Chairside }\end{array}$ & $\begin{array}{c}\text { Biodegradable } \\
\text { bactericidal }\end{array}$ \\
\hline Elyzol $^{\circledR}$ & Gel & $\begin{array}{l}25 \% \text { metronidazole } \\
\text { benzoate }\end{array}$ & $\begin{array}{c}2 \text { applications } \\
7 \text { day treatment } \\
\text { Chairside }\end{array}$ & $\begin{array}{c}\text { Biodegradable } \\
\text { bactericidal }\end{array}$ \\
\hline
\end{tabular}




\section{Povidone-iodine}

The broad spectrum antibacterial properties of povidone-iodine are well known in medicine. This compound is effective against various periodonthopatic bacteria and against cytomegalovirus activity, a herpes virus implicated in the pathogenesis of periodontitis. Povidone-iodine does not exhibit adverse side effects such as discoloration of teeth and tongue or change in taste as seen with chlorhexidine. It has low potential for developing resistance and adverse effects, broad availability; it is easy to use and has low financial cost. For subgingival irrigation in the treatment of periodontitis, an effective concentration is $10 \%$ povidone-iodine is applied repeatedly by an endodontic syringe to obtain a contact time of at least $5 \mathrm{~min}$. Investigators have also reported a favorable clinical outcome after treating advanced periodontitis with subgingival povidone-iodine and systemic antibiotics (Gossi et al., 1997; Slots, 2002 ).

\section{Sodium hypochlorite}

Sodium hypochlorite has been used as an endodontic irrigant for more than 75 years. Sodium hypochlorite has many of the properties that an ideal antimicrobial agent should possess: broad antimicrobial activity, rapid bactericidal action, relative non-toxicity at use concentrations, no color or staining, ease of access and very low cost. No contraindications have been observed. That sodium hypochlorite application might improve periodontal histological healing was suggested by Perova et al. (Perova et al., 1990). Considering sodium hypochlorite significant antimicrobial properties and good safety profile and the promising reaserch data, it seems logical to recommend hypochlorite subgingival irrigation as part of patient's oral self-care regimen.

\section{Chlohexidine}

The use of chlohexidine as an auxiliary antibacterial and antifungal agent in dentistry has a long tradition and has been well documented. As a highly cationic compound, it remains on oral surfaces for a prolonged period after a single usage.

Chlohexidine is a diphenyl compound that is effective against bacteria and exhibits limited activity against viruses. Chlorhexidine gluconate $(0,12 \%)$, such as Peridex ${ }^{\circledR}$ and Periogard $^{\circledR}$, is sold in the United States by prescription only. It is more effective against Gram positive than Gram negative bacteria. Chlorhexidine $0,12 \%$ is indicated in shortterm (less than 2 monts) use, intermittent short-term (alternating on and off every 1 to 2 monts) and long term use (longer than 3 months), depending on clinical conditions. Unfortunatelly, even low concentrations may be toxic to gingival fibroblasts and reduce the production of collagen and non-collagen proteins, potentially impeding periodontal healing (Marrioti and Rumpf, 1999).

\section{Corticosteroids for local application on the periodontium}

Corticosteroids are a group of drugs that has been used in every aspect of clinical medicine due to their potent anti-inflammatory and immunosuppressant properties (Savage and McCullogh, 2005).

The anti-inflammatory action of administered corticosteroids are as a result of several different mechanisms. Topically, their predominant anti-inflammatory action appears to be on eicosanoid formation. Corticosteroids stimulate the production of various polypeptides, collectively called lipocortin that inhibits phospholipase A2 activity. Another corticosteroid induced-complex, vasocortin has been found to inhibit oedema formation. Corticosteroids are thought to in some ways stabilize lysosomal membranes, thus suppressing the release of lytic enzymes (Fachin et al., 2009).

Several animal studies have confirmed that systemic administered steroids have adverse effects on the periodontium and its response to bacterial plaque (Seymour, 2006). Experimental studies have demonstrated that the use of systemic corticosteroids can provoke many conditions, from gingival ulceration to the downmigration of the epithelium, attachment loss and disruption of transseptal fibers (Garsia et al., 2010).

There are few studies that address the effect of locally applied corticosteroids on periodontal healing. When steroids are injected directly into the gingival tissue, they cause a histological reduction in capillary permeability, a reduction in plasma cells and granulation tissue, an inhibition of collagen synthesis and a clinical improvement in hemmoragic and hypoplastic gingivitis (Safkan and Knuuttila, 1984). Although studies about local application of corticosteroids are scarse in literature, current research data suggest that corticosteroids show favorable effect on periodontal healing and posses antiresorbtive effects. Dexamathasone directly affects osteoclast formation and activity, stimulating the proliferation and differentiation of human osteoclast precursors, and inhibiting the bone resorbtion activity in mature osteoclasts (Hirayama et al., 2002). Teeth treated with $0.05 \%$ clobetasol and $0.05 \%$ fluocinonide show favorable periodontal healing; the higher potency corticosteroid clobetasol exerts more favorable healing than the lower potency fluocinonide. It remains unclear whether the antiresorbtive effect of these compounds can be further enhanced by using corticosteroid with increased potency and its anti-inflammatory properties. Although concern exists that the use of corticosteroids locally in the periodontium may induce hypothalamus-pituitary-adrenal axis, it has been reported that the highest possible amounts used are unlikely to result in any systemic side effect (Kirakozova et al., 2009).

Budesonide is a new generation corticosteroid with potent local anti-inflammatory effect which could be used in the treatment of periodontal disease. Animal studies have 
shown that inhaled budesonide could not modulate periodontal breakdown. This might be due to inappropriate formulation and dosage. Additional studies are needed to estimate the effects of budesonide on the oral mucosa and the periodontium (Daudt et al., 2011).

While topical application of corticosteroids for skin disorders is well documented, there is considerably less critical information available for lesions of the oral mucosa, including periodontal disease. Therefore, there is a need for further research into therapeutic systems that improve local delivery of corticosteroids to oral mucosa and periodontium as well as controlled clinical studies in order to evaluate the clinical effectiveness of these formulations attended for treatment of periodontal lesions.

\section{Host modulatory therapies}

In periodontal disease, typical antimicrobial intervention procedures, such as scaling and root planning (SRP), boast some success in removing etiologic agents associated with inflammation, thereby helping to arrest periodontitis. However, such procedures do not inhibit the host mediated tissue destruction and do not offer necessary resolution of inflammation to restore tissue homeostasis (Van Dyke, 2008).

Ever since 1985, research in periodontics has been focused closely on bacterial-host interaction, leading to "hostbacterial interrelationship era". During this era it was recognized that although there is evidence that specific bacterial pathogens initiate pathogenesis of disease, the host response to these pathogens is equally important in mediating connective tissue breakdown and bone loss. It has become evident that host-derived inflammatory mediators such as matrix metalloproteinases (MMPs), cytokines and other inflammatory molecules such as $\mathrm{PGE}_{2}$ are responsible for the majority of tissue destruction in the periodontium.

This shift has led to the development of the so called Host Modulatory Therapies (HMT) which can improve therapeutic outcomes, slow the progression of the disease, allow for more predictable management of patients and possibly even work as preventive agents against the development of periodontits (Thompson, 2001; Reddy et al, 2011).

In the last two decades scientists have investigated various host modulating strategies in both animal and human experimental models. Up to date, specific aspects considered for modulation of periodontitis pathogenesis include:

- regulation of production of arachidonic acid metabolites

- regulation of bone remodeling

- regulation of matrix metalloproteinase (MMPs) activity

- regulation of nitric oxide synthase activity

\section{Nonsteroidal anti-inflammatory drugs (NSAIDs)}

Arachidonic acid (AA) is a 20-carbon polyunsaturated fatty acid (eicosanoid) liberated from membrane phospholipids by the action of phospholipase $\mathrm{A}_{2}$. Free AA is metabolized via cyclooxygenase (COX) or lypooxygenaze (LO) pathways. AA is enzymatically oxidized by COX leading to synthesis of prostanoids (prostaglandins, prostacyclin and tromboxan) or by the action of $\mathrm{LO}$ to form leukotrienes. Over decades, AA metabolites have been established as mediators of tissue destruction in various inflammatory conditions such as rheumatoid arthritis and periodontal disease.

The non-steroidal anti-inflammatory drugs are a group of pharmacological agents that has been well studied as an inhibitor of the host response in periodontal disease. These agents have been shown to prevent formation of arachidonic acid metabolites, especially prostaglandins which have an important role in the pathogenesis of periodontitis (Salvi and Lang, 2005; Kirkwood et al., 2007).

In vitro and in vivo preclinical studies using NSAIDs have shown the extensive ability of these drugs to reduce prostanoid formation by inhibiting COX enzymes. Suppression of osteoclast differentiation, as measured by decreased osteoclast numbers and concomitant decreased alveolar bone resorbtion, is the most frequent sequela following systemic or local delivery of NSAIDs (Kirkwood et al., 2007)

Several adjunctive clinical trials have been conducted with NSAIDs. In a systematic review (Reddy et al., 2003), ten clinical studies, in which the therapeutic outcome of NSAIDs were expressed as clinical attachment level or alveolar crestal hight were selected. In these trials, a variety of different NSAIDs, including flubiprofen, meclofenamate, ibuprofen, ketorolac, naproxen and aspirin, were systemically or locally administered. The limited quantitative analysis tended to show significant benefit related to alveolar bone preservation when NSAIDs were associated with conventional therapy.

More recently, a selective COX-2 inhibitor (nimesulide)/scaling and root planning therapy was compared with a non-selective COX inhibitor (naproxen)/scaling and root planning on periodontal clinical parametars and on gingival tissue levels of prostaglandin $\mathrm{E}_{2}$. No additional increase was observed in clinical attachment levels and probing depth reduction after both adjunctive therapies when compared with a placebo/ scaling and root planning group.

Based on clinical results to date, additional long-term studies are necessary to provide support for the adjunctive use of NSAIDs in the treatment of periodontal disease (Kirkwood et al., 2007).

\section{Biphosphonates}

Alveolar bone resorbtion is the principal sequel and the cause of tooth loss in patients afflicted by periodontal disease. The use of bone-sparing agents such as biphospho- 
nates that inhibit alveolar bone resorbtion is another field in host-modulation therapy.

Biphosphonates are a class of drugs structurally similar to pyrophosphate, a component of human bone metabolism. It binds to hydrohyapatite crystals of bone and prevents their dissolution by interfering with osteoclasts function through a variety of direct and indirect mechanisms (Rogers et al., 2000). As therapeutic agents, biphosphonates were shown to reduce alveolar bone loss and increase mineral bone density, but there was no improvement in clinical conditions in animal periodontitis models (Reddy et al., 1995). Five studies that assessed the effect of biphosphonates as an adjunctive agent to scaling and root planning in human periodontal treatment have been found to date. Aledronate was used in four studies and risendronate was used in a 12-month study. All the studies presented significant clinical improvement when compared with placebo. These results encourage the use of biphosphonates as adjunctive agents to periodontal therapy. However, additional studies are further needed in order to evaluate the relative risk-benefit ratio of biphosphonate therapy.

\section{Regulation of matrix metalloproteinase activity}

Matrix metalloproteinases (MMPs) represent a family of zinc-dependent membrane-bound and secreted proteolytic enzymes. Their main function is to catalyze the breakdown of proteins in the cell plasma membrane or within the extracellular matrix (Salvi and Lang, 2005). Deregulation of MMPs activity is involved in a variety of pathological conditions such as rheumatoid arthritis, tumor cell metastasis and periodontal disease (Yoon et al., 2003).

The ability of tetracycline and doxycycline to inhibit MMP activity was first identified in the early 1980s. Tetracyclines block the active enzyme and inhibit reactive oxygen species that might be involved in the activation of these enzymes (Kornman, 1999).

Initial studies have demonstrated that doxycycline was the most potent tetracycline in the inhibition of collagenolytic activities. A subantimicrobial dose $(20 \mathrm{mg}$ twice daily) of doxycycline (SDD) with the purpose of long term administration in patients suffering from periodontitis was introduced and shown to down regulate collagenase activity without the emergence of doxycycline-resistant microorganisms or typical adverse events (Salvi and Lang, 2005). Thus far, one approved host modulation therapy (HMT) prescribed as systemic SDD (Periostat ${ }^{\circledR}$, CollaGenex Pharmaceuticals Inc., Newtown, PA, USA) in conjunction with mechanical periodontal therapy is available in some countries (Bostanci et al., 2011).

\section{Nitric oxide synthase (NOS) inhibitors}

NO is a short-lived molecule implicated in a variety of biological processes ranging from immune homeostasis to cancer (Brennan et al., 2003). It is synthetised in vivo from the substrate L-arginine by three isoenzymes called niric oxide synthases (NOSs).

Oral bacteria have been postulated to trigger iNOS upregulation in periodontal tissues (Lohinai et al., 2001). Being highly reactive, NO attacks thiol residues inducing lipid peroxidation, protein and DNA damage and stimulating cytokine release (Brennan et al., 2003). Although NO has an antimicrobial protective activity, its elevated concentration in periodontium has a cytotoxic effect towards host cells.

Nitric oxide synthase (NOS) inhibitors such as marcaptoethylguanidine have demonstrated protective effects against bone resorbtion and inflammatory process in ligature-induced periodontitis in rats (Lohinai et al., 1998; Leitao et al., 2005). Since several studies have confirmed that NO has a deleterious role in the pathophysiology of periodontitis, the modulation of its activity may prevent tissue destruction.

\section{Disruption of cell signaling pathways as an approach in the treatment of periodontits}

Strategies for preventing cell activation seek to inhibit the intracellular transduction of signals produced when ligands bind to their membrane receptors. Signal transduction pathways are activated not only by cytokines, but also by other factors, such as bacterial proteins, lipopolysaccaharide, or environmental stress. These stimuli act on receptors that are coupled to the signal transduction pathways, causing activation of transcription factors and other proteins that control of cytokines, proteases and many other compounds involved in the inflammatory process. Inhibition of signal transduction pathways would be expected to abolish cell activation by cytokines or other stimuli and the production of pro-inflammatory cytokines. Cytokines and bacterial components activate many signal transduction pathways. The most important signal transduction pathways in periodontal disease include the mitogen activated protein kinase (MAPK), nuclear factor kappa B (NF$\kappa \mathrm{B})$ and janus tyrosine kinase-signal transducer and activator of transcription (JAK/STAT).

\section{The NF- $\kappa B$ pathway}

The transcription factors NF- $\mathrm{B}$ are homo- or heterodimers found in the cytoplasm of most human cells. The NF$\kappa \mathrm{B}$ family of transcription factors has been shown to be involved in many different pathways and has a central role in regulating the expression of a wide variety of genes that control both innate and adaptive immune responces. In vitro studies have established that both $P$. gingivalis and oth-

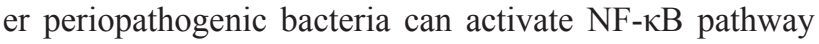
in periodontal tissues (Sugita et al., 1998). Bacterial LPS, IL-1 and TNF- $\alpha$, present in large quantities in periodontal tissues, can also activate NF- $\kappa \mathrm{B}$.

$\mathrm{NF}-\kappa \mathrm{B}$ activation is regulated primarily though inhibi- 
tors of NF- $\kappa \mathrm{B}(\mathrm{I} \kappa \mathrm{B})$. Many strategies to prevent activation of NF $-\kappa B$ are based on the modulation of $I \kappa B$, as proteasome inhibitors that block degradation of $\mathrm{I} \kappa \mathrm{B}$, and overexpression of $\mathrm{I} \kappa \mathrm{B}$ by recombinant protein or gene therapy (Souza et al., 2010). The IKK inhibitor, BMS-345541, was evaluated in collagen-induced arthritis model in mice and decreased both synovial inflammation and joint destruction (McIntyre et al., 2003). Other strategies to block the NF$\kappa \mathrm{B}$ activity that are being developed by pharmaceutical industry are being based on targeting the DNA binding activity of NF- $\kappa \mathrm{B}$ or blocking the nuclear translocation of NF$\kappa \mathrm{B}$ dimers.

Despite the potential use of this pathway in development of therapeutic interventions for immune/inflammatory diseases, NF- $\kappa \mathrm{B}$ also play key role in normal physiological processes. Therefore, general blockade of NF- $\kappa \mathrm{B}$ results in unwanted side effects as liver failure related to hepatocyte apoptosis (Maeda et al., 2003).

\section{The MAPK pathway}

MAPKs represent a family of protein kinases that mediate fundamental biological processes and cellular responses to different extracellular stimuli through multiple receptors (Kyriakis et al., 2001).

MAPKs are divided into three subfamilies: the extracellular signal regulated kinases (ERK1/2); JNKs; and p38 which are all assumed to be expressed in periodontal lesions.

The p38 MAPK is activated mainly within cells involved in the inflammatory process. Activation of $\mathrm{p} 38$ induces synthesis of IL-1, IL-6, IL-8 and TNF- $\alpha$, either via direct activation of gene transcription or via mRNA stabilization (Kirkwood et al., 2003)

The role of p38 MAPK in the various stages of inflammation has prompted the production of several imidazole compounds capable of inhibiting p38 (SB203580, RWJJ 67657, L- 167307, VX-745, RPR200765A and others). These pharmacological inhibitors are cytokine suppressive anti-inflammatory drugs (CSAIDSs) responsible for in vitro and in vivo inhibition of lipopolysaccharide-induced TNF- $\alpha$ expression (Adams et al., 2001). They have been evaluated in several murine models of periodontal disease and/or rheumatoid arthritis and have prevented the pregression of the disease and bone resorbtion.

The efficacy of anticytokine biotherapies in patients with inflammatory diseases is a proof that blocking the effects of a cytokine can slow down the disease process. However, MAPKs play significant role of many physiological processes and suppression of their function may lead to a number of problems. One of the reasons for the unacceptable side effects might be the cross reactivity against other kinases or other cellular signaling molecules (Cohen et al., 2002).

\section{JAK/STAT pathway}

Many cytokines and growth factors (interferons, interleukins, epidermal growth factor, growth hormone, erythropoietin and others) exert their biological functions through JAK/STAT signal transduction pathway. The JAK/STAT pathway is the signaling target of many cytokines which are thought to have biologically significant roles in periodontal disease (INF- $\gamma$, INF- $\alpha$, IL-1, IL-4, IL-6, and IL10). Several studies have shown that STAT pathways are activated in a ligature-induced experimental periodontitis in rats (Garsia de Aquino et al., 2009). To date no studies with STAT inhibitors are available in periodontal disease despite the potential role of these proteins in expression of important genes related with inflammatory diseases.

It is now clear that JAK/STAT pathway have a fundamental role in inflammatory diseases onset and progression. This pathway can affect the expression of various genes with pro-inflammatory and anti-inflammatory activity. Furthermore, the modulation of this pathway on cytokine signaling increases the possibility that these proteins may prove to be excellent targets for the discovery of drugs that can manipulate cytokine outcomes to resolve disease.

\section{Tumor necrosis factor antagonists to block inflammatory diseases}

TNF- $\alpha$ and IL-1, inflammatory cytokines, are released by activated monocytes, macrophages and $\mathrm{T}$ lymphocytes. They promote inflammatory responses that are of great importance in rheumatoid arthritis and periodontal disease.

Patients with rheumatoid arthritis and periodontal disease have high concentration of TNF- $\alpha$ in the synovial fluid and gingival crevice fluid, respectively. Both, TNF- $\alpha$ and IL-1, have been found in high concentrations in periodontal lesions and at sites of active bone resorbtion (Ejeil et al., 2003; Gamonal et al., 2000; Gorska et al., 2003). Reduction of the bacteria and their metabolic by-products by periodontal treatment also results in a decrease in both IL-1 and TNF- $\alpha$, also paralleled by improvement in clinical parameters (Gamonal et al., 2000)

The use of cytokine receptor antagonists to inhibit periodontal disease progression investigated in a ligatureinduced periodontitis non human primate model partially inhibited disease progression (Delima et al., 2001). Etanercept is a dimeric, soluble form of $75-\mathrm{kDa}$ TNF- $\alpha$ receptor. The anti-inflammatory effects of etanercept are a result of its ability to bind to TNF- $\alpha$, preventing it from interacting with cell surface receptors and rendering it biologically inactive. Etanercept can also modulate biological responces that are induced or regulated by TNF- $\alpha$. In an animal study, etanercept demonstrated significant effect on plasma extravasation periodontitis. Further results indicated that etanercept treatment reduced the expression of iNOS and prevented the loss of antiapoptotic pathway in, as yet, unidentified mechanism (Di Paola et al., 2007). 
At present, non-glycosilated sIl-1Ra, known as Anakinra (Kineret, Amgden Inc., Thousand Oaks, CA, USA) has been used to treat rheumatoid arthritis (RA) and other rheumatic disorders (Burger et al., 2006). Recent clinical studies indicate that Anakinra is safe and well tolerated treatment suitable for long term use in RA, although its anti-inflammatory effects are inferior to those of anti-TNF- $\alpha$ treatments, due possibly to its short half-life (Cohen et al., 2002; Fleischmman et al., 2006).

Infliximab and adalimumab are novel anti-TNF- $\alpha$ therapy used in the treatment of rheumatoid arthritis. Several studies have evaluated the influence of this treatment on periodontal parametars. The results from the studies suggest that patients on anti-TNF- $\alpha$ therapy exert lower GCF levels of TNF- $\alpha$ and milder periodontal disease compared with patients who do not receive this medication (Ortiz et al., 2009; Persson, 2012).

Blocking the activity of pro-inflammatory cytokines may be a benefitial therapeutic modality for periodontitis. The blockage of TNF- $\alpha$ pathway offers significant potential in blocking disease progression and would probably positively influence host defense functions.

\section{Nutrients as modulators of inflammation in periodontits}

Omega-3 fatty acids have been demonstrated to protect mice against numerous bacteria. These compounds inhibit the synthesis of lipid mediators of inflammation (prostaglandins and arachidonic acid), alter the cellular functions of polymorphonuclear leukocytes and modulate lymphocyte proliferation and cytokine production. In addition, these compounds have been shown to increase endogenous host anti-oxidant capacity. A recent study investigated the synergistic anti-inflammatory effects of omega-3 fatty acids and celecoxib. The combined therapy resulted in superior reductions on periodontal tissue levels of prostaglandins, leukotriene B4 and platelet activating factor, which is also a pro-inflammatory mediator. No significant effect was observed on bone loss, which was related to the short period of evaluation (Vardar et al., 2005). These therapeutic modalities require further epidemiological studies for evaluation of the relations between nutritients with antioxidant properties and periodontal disease.

\section{Summary}

On the basis of current clinical data, it seems reasonable to conclude that the immunoinflammatory response is sufficiently protective in most patients such that minimal periodontal destruction will occur with routine oral hygiene. Regular bacterial control, such as scaling and root planning, seems to be the most practical approach in periodontal therapy.

For individuals who exhibit severe aggressive periodontitis or other highly susceptible populations (smok- ers, diabetes patients, patients positive for the IL-1 phenotype) host modulation seems to be an appropriate therapeutic strategy.

A variety of treatment strategies have been developed to target the host response to periodontal infection. MMP inhibitors such as low dose formulations of doxycycline have been used in combination with SRP or surgical therapy. In addition, high-risk patient groups such as diabetics or patients with recurrent periodontitis have benefited from the systemic MMP administration. Encouraging results have been obtained following soluble antagonists of TNF- $\alpha$ and IL-1 delivered locally in non-human primates. Other therapeutic strategies that are being explored involve inhibition of signal transduction pathways involved in inflammation. Pharmacological inhibitors of NF- $\mathrm{BB}$ and p38 mitogen activating protein (MAP) kinase pathways are actively being developed to manage inflammatory bone diseases. P38 inhibitors have shown promise in preclinical models of periodontal disease.

Using these novel strategies may provide the next generation of adjuvant chemotherapeutics to manage chronic periodontitis. It seems likely that host modulators together with control of the bacterial challenge will become a practical approach to the management of patients with increased risk for periodontal disease.

\section{References}

Abdellaoui-Schwach, K., Castioni-Vivien, N., Gurny, R., 2000. Local delivery of antimicrobial agents for the treatment of periodontal diseases. Eur. J. Pharm. Biopharm. 50, 83-99.

Adams, L.J., Badger, M.A., Kumar, S., Lee, J.C., 2001. P38 Map kinase: molecular target for the inhibition of proinflammatory cytokines. Prog. Med. Chem. 38, 1-60.

Baker, J.P., 2000. The role of immune responces in bone loss during periodontal disease. Microbes infect. 2, 1181-1192.

Bostanci, N., Akgul, B., Tsakanika, V., Allaker, P.R., Hughes, J.F., McKay, J.I., 2011. Effect of low dose doxycycline on cytokine secretion in human monocytes stimulated with Aggregatibacter actinomycetemcomitans. Cytokine 56, 656-661.

Brandztaeg, P., 2001. Inflammatory bowel disease: clinics and pathology. Do inflammatory bowel disease and periodontal disease have similar immunopathogenesis? Acta Odon. Scand. 59, 235-243.

Brennan, A.P., Thomas, J.G., Langdon, D.J., 2003. The role of nitric oxide in oral diseases. Arch. Oral Biol. 48, 93-100.

Bottura, E.P., Milanezi, J., Fernandes, A.L., Caldas, C.H., Filho-Abbud, M., Garsia G.V., Baptista, F.S.A.M., 2011. Nonsurgical periodontal therapy combined with laser and photodynamic therapies for periodontal disease in immunosupressed rats. Trans. Proceed. 43, 2009-2016.

Burrell, R. and Walters, J., 2008. Distribution of systemic claritromycin to gingiva. J. Periodontol. 79, 1712-1718.

Burger, D., Dayer, J.M., Palmer, G., Gabay, C., 2006. Is IL-1 a good target in the treatment of arthritis? Best Prac. Res. Clin. Rheumatol. 20, 879-896.

Chou, H.C., Walters, D.J., 2008. Clarithromycin transport by gingival fibroblasts and epithelial cells. J. Dent. Res. 87, 777-781. 
Cohen, S., Hurd, E., Cush, J., 2002. Treatment of rheumatoid arthritis with anakinra, a recombinant human interleukin-1 receptor antagonist, in combination with metotrexate: results of a twenty-four-week, multicenter, randomized, doubleblind, placebo-controlled trial. Arthritis Rheum. 46, 614-624.

Dastoor, F.S., Travan, S., Neiva, F.R., Rayburn, A.L., Giannobile, V.W., Wang, L.H, 2007. Effect of adjunctive systemic azythromycin with periodontal surgery in the treatment of chronic periodontitis in smoker: a pilot study. J. Periodontol. 78, 1887-1896.

Daudt, D.L., Cavagni, J., Gaio, J.E., Souza, A., Torres, S.L.I., Ferreira, C.B.M., Rosing, K.C., 2011. Effect of inhaled corticosteroid on TNF $-\alpha$ production and alveolar bone loss in Wistar rats. Arch. Oral Biol. 56, 1398-1403.

Delima, A.J., Oates, T., Assuma, R., Schwarz, Z., Cochran, D., Amar, S., Graves, D.T., 2001. Soluble antagonists to interleukin-1 (IL-1) and tumor necrosis factor (TNF) inhibits loss of tissue attachment in experimental periodontitis. J. Clin. Periodontol. 28, 233-240.

Di Paola, R., Mazzon, E., Muia, C., Crisafulli, C., Terrana, D., Greco, S., Britti, D., Santori, D., Oteri, G., Cordasco, G., Cuzzocrea, S., Effects of etanercept, a tumor necrosis factoralpha antagonist, in an experimental model of periodontits in rats. Brit. J. Pharmacol. 150, 286-297.

Drisko, H.C., 2001. Non surgical periodontal therapy. Periodontol. $200025,77-88$.

Ejeil, A.L., Gaultier, F., Igondjo-Tschen, S., Senn, K., Pellat, B., Godeau, G., Gogly, B., 2003. Are cytokines linked to collagen breakdown during periodontal disease progression? J. Periodontol. 74, 196-201.

Fachin, E., Scarparo, R., Pezzi, A., Luisi, S., Filho, M., 2009. Effect of betamethasone on the pulp after topical application to the dentin of rat teeth: vascular aspects of inflammation. J. Appl. Oral Sci. 17, 335-339.

Fleishmann, R.M., Tesser, J., Schiff, M.H., 2006. Safety of extended treatment with anakinra in patients with reumatoid arthritis. Ann. Rheum Dis. 83, 384-7.

Gamonal, J., Acevedo, A., Bascones, A., Jorge, O., Silva, A., 2000. Levels of interleukin-1 beta, -89 , and -10 and RANTES in gingival crevicular fluid and cell population in adult periodontitis patients and the effect of periodontal treatment. J. Periodontol. 71, 1535-1545.

Garsia, G.V., Fernandes, A.L., Almeida, M J., Bosco, F.A., Hitomi, J.M., Martins, M.T., Okamoto, T., Theodoro, H.L., 2010. Comparison between laser therapy and non-surgical therapy for periodontitis in rats treated with dexamethasone. Las. Med. Sci. 25, 197-206.

Ghabachi, J., Bahri Najafi, R., Haghnegahdar, S., Treatment of oral inflammatory diseases with a newmucoadhesive prednisolone tablet versus triamcinolone acetonide paste. Iran. Red Cresc. Med. 11(2), 155-159.

Gossi, G.S., Skrepcinski, B.F., Decaro, T., 1997. Treatment of periodontal disease in diabetics reduces glucated hemoglobin. J. Periodontol. 68, 713-719.

Goodson, M.J., Gunsolley, C.J., Grossi, S., Bland, S.P., CorgelOtomo, J., Doherty, F., Comiskey, J., 2007. Minocycline $\mathrm{HCl}$ microsperes reduce red-complex bacteria in periodontal disease therapy. J. Periodontol. 78, 1568-1579.

Goracinova, K., Glavas-Dodov, M., Simonoska-Crcarevska, M., Geskoski, N., 2012. Inflammatory Bowel DiseasesAdvances in Pathogenesis and Management, ISBN: 978953-307-891-5, InTech, Croatia.

Gorska, R., Gregorek, H., Kowalski, J., Laskus-Perendyk, A.,
Syczewska, M., Madalinski, K., 2003. Relationship between clinical parametars and cytokine profiles in inflamed gingival tissue and serum samples from patients with chronic periodontitis. J. Clin. Periodontol. 30, 1046 - 1052.

Greenstein, G., 2000. Nonsurgical periodontal therapy in 2000: A literature review. JADA 131, 1580-1592.

Hajishengallis, G., Lambris, D.J., 2012. Complement and dysbiosis in periodontal disease. Immunobiology 217, 1111-1116.

Haffajee, D.A., Socransky, S.S., 1994. Microbial ethiological agents of destructive periodontal disease. Periodontol. 2000, 78-111.

Horz, H.P. and Conrads, G., 2007. Diagnosis and anti-infective therapy of periodontitis. Expert Rev. Anti. Infect. Ther. 5, 703-715.

Herrera, D., Matesanz, P., Martinez-Bascones, A., Sanz, M., 2012. Local and systemic antimicrobial therapy in periodontitis. J. Evid. Base. Dent. Pract. 51, 50-60.

Hirsch, R., Deng, H., Laohachai, N.M., 2012. Azithromycin in periodontal treatment: more than an antibiotic. J. Periodont. Res. 1-12.

Hirayama, T., Sabokbar, A., Athanasou, A.N., 2002. Effect of corticosteroids on human osteoclast formation and activity. J. Endoc. 175, 155-163.

Hwa-Jeong, L., Jin-Woo, C., Sang-Cheol, K., Kyung-Hwa, K., Sun-Kyung, L., Sung-Hee, P., Suk-Keun, L., Eun-Cheol, K., 2006. Roles of p38 and ERK MAP kinases in Il-8 expression in TNF- $\alpha$ - and dexamathasone-stimulated human periodontal ligament cells. Cytokine 35, 67-76.

Hyrayama, T., Sabokbar, A., Athanasou, N.A., 2002. Effect of corticosteroids on human osteoclast formation and activity. J. Endo. 175, 155-163.

Iskandar, I. and Walters, J., 2011. Claritromycin Accumulation by phagocytes and its effect on killing of Aggregatibacter actinomycetemcomitans. J. Periodontol. 82, 497-504.

Jain, N., Jain, G., Javed, S., Iqbal, Z., Talegaonkar, S., Ahmad, F., Khar, R., 2008. Recent approaches for the treatment of periodontitis. Drug Discover. Today 13, 932-943.

Kantarci, A., Van Dyke, T., 2005. Lipoxin signaling in neutrophils and their role in periodontal disease. Prostaglandins, leukotrienes and essential fatty acids 73, 289-299.

Kinane, D.F., Attstrom, R., 2005. Advances in the pathogenesis of periodontitis. J. Clin. Periodontol. 32, 130-131.

Kinane, F.D., Lowe, D.G., 2000. How periodontal disease may contribute to cardiovascular disease. Periodontol. 23, 121-126.

Kirkwood, L.K., Martin, T., Andreadis, T.S., Kim, J.Y., 2003. Chemically modified tetracyclines selectively inibit IL-6 expression in osteoblasts by decreasing mRNA stability. Biochem. Pharmacol. 66, 1809-1819.

Kirkwood, L.K., Cirelli, J., Rogers, J., Giannobile, W., 2007. Novel host responce therapeutic approaches to treat periodontal diseases. Periodontol. 2000 43, 294-315.

Kirakozova, A., Texeira, F., Curran, A., Gu, F., Tawil, P., Trope, M., 2009. Effect of intracanal corticosteroids on healing of replanted dog teeth after extended dry times. J. Appl. End. 35, 663-667.

Kornman, S.K., 1999. Host modulation as a therapeutic strategy in the treatment of periodontal disease. Clin. Inf. Dis. 28, 520-526.

Krayer, W. J., Leite, S. R., Kirkwood, L.K., 2010. Non-surgical chemotherapeutic treatment strategies for the management of periodontal diseases. Dent. Clin. North. Am. 54, 1-23.

Kyriakis, M.J. and Avruch, J., 2001. Mammalian mitogenactivated protein kinase signal transduction pathways 
activated by stress and inflammation. Physiol. Rev. 81, 807869.

Lai, P., Ho, W., Jain, N., Walters, J., 2011. Azithromycin concentrations in blood and gingival crevicular fluid after systemic administration. J. Periodontol. 82, 1582-1586.

Leitao, F.R., Ribeiro, A.R., Chaves, V.H., Rocha, A.F., Lima, V., and Brito, A.G., 2005. Nitric oxide synthase inhibition prevents alveolar bone resorbtion in experimental periodontitis in rats. J. Periodontol. 76, 956-63.

Liu, D. and Yang, S.P., 2012. Minocycline hydrochloride nanoliposomes inhibit the production of TNF- $\alpha$ in LPSstimulated macrophages. Inter. J. Nanomed. 7, 4769-4775.

Lohinai, Z., Stachlewitz, R., Virag, L., Szekely, D.A., Hasko, G., Szabo, C., 2001. Evidence for reactive oxygen species formation in gingivomucosal tissue. J. Dent. Res. 80, 470-475.

Lohinai, Z., Bendek, P., Feher, E., Gyorfi, A., Rosivalli, L., Fazekas, A., Salzman, L.A., Szabo, C., 1998. Protective effects of mercaptoethylguanidine, a selective inhibitor of inducible nitric oxide synthase, in ligature induced periodontitis in rats. Brit. J. Pharm. 123, 353-360.

Maeda, S., Chang, L., Li, W.Z., Luo, L.J., Leffert, H., Karin, M., 2003. IKK, beta is required for prevention of apoptosis mediated by cell-bound but not circulating TNF alpha. Immunity 19, 725-737.

Mariotti, J.A., Rumph, A.D., 1999. Chlohexidine-induced changes to human gingival fibroblast collagen and noncollagen protein production. J. Periodontol. 70, 1443-1448.

McIntyre, W.K., Shuster, J.D., Gilloly, M.K., Dambach, M.D., Pattoli, A.M., Lu, P., 2003. A highly selective inhibitor of I kappa B kinase, BMS-345541, blocks both joint inflammation and destruction in collagen-induced arthritis in mice. Arthritis Rheum. 48, 2652-2659.

Ortiz, P., Bissada, N.F., Palomo, L., Han, Y.W., Al Zahrani, M.S., Pannerselvam, A., Askari, A., 2009. Periodontal therapy reduces the severity of active rheumatoid arthritis in patients treated with or without tumor necrosis factor inhibitors. J. Periodontol. 80, 535-540.

Perova, D.M., Lopunova, K.Z., Banchenko, V.G., Petrosian, A.E., 1990. A clinico-morphological assessment on the efficacy of sodium hypochlorite in the combined therapy of periodontitis. Stomatologia (Mosk) 69, 23-26.

Persson Rutger, G., 2012. Rheumatoid arthritis and periodontitis - inflammatory and infectious connections. Review of the literature. J. Oral Microbiolog. 4, 11829.

Radvar, M., Pourtaghi, N., Kinane, F.D., 1996. Comparison of 3 periodontal local antibiotic therapies in persistent periodontal pockets. J. Periodontol. 67, 860-865.

Reddy, S., Prasad, M.G.S., Kaul, S., Asutkar, H., Bhowmik, N., 2011. Host modulation in periodontics. E-J Dent. 1, 51-62.

Reddy, S.M., Weatherford, W.T., Smith, A.C., West, D.B., Jeffcoat, K.M., Jacks, M.T., 1995. Alendronate treatment of naturally occurring periodontitis in beagle dogs. J. Periodontol. 66,
211-217.

Rogers, J.M., Gordon, S., Benford, L.H., Coxon, P.F., Luckman, P.S., Monkkonen, J., Frith, C.J., 2000. Cellular and molecular mechanisms of action of biphosphonates. Cancer 88, 29612978.

Savage, W.N., McCullogh, J.M., 2005. Topical corticosyeroids in dental practise. Aust. Dent. J. 50, 40-44.

Salvi, G.E., Lang, N.P., 2005. Host response modulation in the management of periodontal disease. J. Clin. Periodontol. 32, 108-129.

Safkan, B., Knuuttila, M., 1984. Corticosteroid therapy and periodontal disease. J. Clin. Periodontol. 11, 515-522.

Seymour, A.R., 2006. Effects of medications on the periodontal tissues in health and disease. Periodontol. 2000 40, 120129.

Slots, J., 2002. Selection of antimicrobial agents in periodontal therapy. J. Periodont. Res. 37, 389-398.

Slots, J., Ting, M., 2002. Systemic antibiotics in the treatment of periodontal disease. Periodontol. 2000 28, 106-176.

Souza, J., Rosaa, J.C., Garlet, G., Nogueira, A., Cirreli, J., 2012. Modulation of cell signalling pathways as a therapeutic approach in periodontal disease. J. Appl. Oral. Sci. 20, 128138.

Sugita, N., Kimura, A., Matsuki, Y., Yamamoto, T., Yoshie, H., Hara, K., Activation of transcription factors and ILexpression in neutrophills stimulated with lipopolysacharide from Porphyromonas gingivalis. Inflammation 22, 253-267.

Suresh, S., 2011. A new paradigm in Autoimmunity - role in periodontal disease.Ind. J. Dent. Advanc. 3, 583-586.

Thorbur, D., Ferguson, M.M., 1994. Topical corticosteroids and lesions of the oral mucosa. Adv. Drug Deliver. Rev. 13, 135149.

Tomson, G.R., 2001. Modulating the host response as an adjunctive treatment for periodontitis. J. Periodontol. 22, 2634.

Van Dyke, T., 2008. The management of inflammation in periodontal disease. J. Periodontol. 79, 1601-1608.

Vardar, S., Buduneli, E., Basylas, H., Berdeli, A.H., Buduneli, N., Atilla, G., 2005. Individual and combined effects of selective cyclooxygenase- 2 inhibitor and omega-3 fatty acids on endotoxin-induced periodontitis in rats. J. Periodontol. 76, 99-106.

Walters, J., 2006. Characterisation of minocycline transport by human neutrophils. J. Periodontol. 77, 1964-1968.

Winkel, E.G., Van Winkelhoff, A.J., Timmerman, M.F., Van der Velden, U., Van der Weijden, G.A., 2001. Amoxicillin plus metronidazole in the treatment of adult periodontitis patients. A double-blind placebo-controlled study. J. Clin. Periodontol. 28, 296-305.

Yoon, O.S., Park, J.S., Yun, H.C., Chung, A. S., 2003. Role of matrix matalloproteinases in tumor metastasis and angiogenesis. J. Biochem. Mol. Biol. 36, 128-137. 


\title{
Резиме
}

\section{Терапевтски пристапи во третманот на пародонталната болест}

\author{
Лилјана Богдановска ${ }^{1}$, Силвана Кукеска², Мирјана Поповска ${ }^{3}$, Руменка Петковска $^{1}$ \\ и Катерина Горачинова ${ }^{2 *}$
}

\author{
${ }^{1}$ Институт за применета хемија и фармацевтски анализа, Фармацевтски факултет, \\ Универзитет „,Св. Кирил и Методиј“, Скопје \\ ${ }^{2}$ Институт за фармацевтска технологија, Фармацевтски факултет, \\ Универзитет „Св. Кирил и Методиј“, Скопје \\ ${ }^{3}$ Клиника за болести на уста и пародонт, Стоматолошки факултет, \\ Универзитет „, Св. Кирил и Методиј“, Скопје
}

Клучни зборови: пародонтопатија, терапија на пародонтална болест, антибиотици, антисептици, имуномодулаторен агенс

Пародонтопатијата претставува хроничен инфламаторен процес кој ги зафаќа потпорните структури на забите. Оваа болест започнува како резултат на инфекција со периопатогени бактерии на места кои се предиспонирани за развој на болеста. Бактериската инвазија води кон развој и прогресија на болеста која резултира во зафатеност на сите структури на пародонтот меѓу кои и ресорбција на алвеоларна коска. Иако механичкиот, нехируршки третман на пародонталната болест е основен третман, тој поседува одредени недостатоци како што се ограничена можност за третман на длабоките пародонтални џебови, како и олеснета миграција на периопатогени бактерии од други места во усната шуплина. Со цел да се надминат овие ограничувања, како дополнување на основниот третман се користат хемотерапевтици и имуномодулаторни агенси. Примената на овие агенси во комбинација со механички третман покажува значително поголем терапевтски ефект во споредба со ефектот добиен со механички третман. Во овој труд ќ биде направен преглед на хемотерапевтиците, како и имуномодулаторните агенси кои се користат во третманот на пародонталната болест. 


\title{
Molecular profile of the Lynch Syndrome in the Republic of Macedonia
}

\author{
Marija Hiljadnikova-Bajro ${ }^{1}$, Toni Josifovski ${ }^{2}$, Milco Panovski ${ }^{2}$, \\ Aleksandar J. Dimovski* \\ ${ }^{1}$ Institute of Applied Biochemistry, Faculty of Pharmacy, University "Ss Cyril and Methodius", \\ Skopje, Republic of Macedonia \\ ${ }^{2}$ University Clinic for Digestive Surgery, Medical Faculty, University "Ss Cyril and Methodius", \\ Skopje, Republic of Macedonia \\ ${ }^{3 *}$ Center for Biomolecular Pharmaceutical Analyses, Faculty of Pharmacy, University "Ss Cyril and Methodius", \\ Skopje, Republic of Macedonia
}

Received: November 2012; Accepted: December 2012

\begin{abstract}
The most frequent type of hereditary colorectal cancer, the one occurring in the setting of the Lynch syndrome (LS) is considered a phenotypic manifestation of a germline defect in the mismatch repair mechanism i.e. in the MLH1, MSH2, MSH6 or PMS2 gene. Aiming towards establishment of a standardized protocol involving molecular analyses for diagnosis of this syndrome and developing a unique national register of families with hereditary colorectal cancer syndromes in the Republic of Macedonia, we began a prospective study to reveal the genetic defects among Macedonian patients with colorectal cancer (CRC) and identifying families with hereditary CRC.

A total of 53 patients fulfilling the revised Bethesda criteria for MSI-genetic testing were compared to 350 patients with sporadic CRC. The results reveal significant differences in age at diagnosis $(p=0.03)$, involvement of microsatellite instability $(p<0.0001)$ and localization of the tumor in respect to flexura lienalis $(\mathrm{p}=0.009)$ and suggest affiliation of the majority of the "Bethesda+" CRCs to the so called Familial Colorectal cancer Type X group. The molecular characterization of LS suspects identified the novel MLH1 c.392C $>$ G nonsense mutation with a possible founder effect in the Macedonian population, the MLH1 ex.3-12 deletion, as well as the c.244A $>\mathrm{G}$ mutation, IVS14$19 \mathrm{~A}>\mathrm{G}$ and IVS4+65A $>\mathrm{C}$ changes in $M L H 1$ without confirmed pathological significance. The observed high frequency ( $87.5 \%)$ of the Ile219Val (c.655A >G) variant in MLH1 among the LS suspects prompts further analyses to evaluate its involvement in the development of hereditary CRC by itself or as a risk modifying factor among the patients from the Republic of Macedonia.
\end{abstract}

Keywords: Colorectal cancer, Lynch syndrome, MLH1, microsatelite instability

\section{Introduction}

The most frequent hereditary form of colorectal cancer (CRC), responsible for 2-4\% of all CRC cases (Aaltonen, 1998; Jasperson, 2010) is the hereditary nonpolyposis colorectal cancer-HNPCC, later renamed to Lynch syndrome (LS). The autosomal dominant pattern of inheritance and

\footnotetext{
*adimovski@ff.ukim.edu.mk
}

tel/fax:++38923126054 penetrance of $85-90 \%$ are important features of this syndrome which is characterized by development of cancers at an early age (45 years on average), predominantly located proximally to flexura lienalis $(70 \%)$, frequent presentation of multiple synchronous or metachronous CRCs as well as an increased risk for extracolonic malignancies affecting the endometrium, ovaries, gaster, intestines, hepatobiliary tract, pancreas, brain and the upper urinary tract (Watson and Lynch, 1994; Aarnio et al., 1999), but some families present with breast cancers also (Risinger et al., 1996). 
The molecular definition of the Lynch Syndrome implies germline mutations in any of the mismatch repair (MMR) genes responsible for the basepair mismatch reparation during DNA replication as: $\mathrm{MLH1}$ and $\mathrm{MSH} 2$ carrying almost $90 \%$ of the mutations, MSH6 holding $10 \%$ of the genetic defects and rare mutations in EPCAM and PMS2.

The initial criteria for the establishment of a clinical diagnosis of LS, the so called Amsterdam I and II criteria (Vasen et al., 1991 and 1994) are based on the familial cancer history, but the revised Bethesda criteria for genetic testing for LS (Umar et al., 2004) are more sensitive and enable identification of LS cases resulting from de novo MMR genetic defects.

Approximately ten to fifteen percent of individuals with $\mathrm{CRC}$ and/or colorectal adenomas have diseased relatives (National Cancer Institute, 2012), but don't meet the criteria for clinical diagnosis of neither LS nor the syndrome of familial adenomatous polyposis. They are considered as cases with familial colorectal cancer (FCC), which might be caused by unidentified genetic factors, exposition of the family members to common environmental risk factors or by chance. Furthermore, families fulfilling the Amsterdam criteria for LS but lacking genetic MMR-defects i.e microsatellite instable tumors, are designated as familial colorectal cancer type X (FCC-X) (Jass, 2006; Mueller-Koch et al., 2005; Valle et al., 2007). The risk for development of CRC is lower among these patients (Lindor et al., 2005) but if a malignant transformation eventually occurs, the diagnosis is usually established at an older age (55 years on average) in comparison to the LS. Further investigations are needed for their precise characterization, but it is quite obvious that tumors arising in FCC-X families feature a specific pathological phenotype with less tumor-infiltrating leukocytes versus typical LS tumors. (Llor et al., 2005).

Currently, there aren't any officially published data on the incidence/prevalence of LS in the Republic of Macedonia and there isn't a unique national register of patients/ families with any of the hereditary colon cancer syndromes, which seriously obstruct the investigation and characterization of this type of hereditary cancer in our country and disable appropriate prevention/treatment. Hence, we began a prospective study to aid the establishment of standardized protocols involving molecular analyses for clinical diagnosis of the Lynch syndrome in our country.

\section{Materials and methods}

From a total of 403 randomly selected patients undergoing colectomy for resection of histopathologically confirmed CRC at the University Clinic for Digestive Surgery in Skopje, a cohort of 53 cases was selected based on fulfillment of the Bethesda clinical criteria for MSI testing and compared to a group of 350 cases with sporadic CRC. Detailed personal and familial history as well as relevant information on dietary and life-style habits were obtained by the responsible clinicians.

The molecular analyses were performed on samples of peripheral blood and fresh tumor tissues obtained by the surgical resection of the cancer. The DNA was isolated using Proteinase K digestion/ phenol- chloroform-isoamylalcohol extraction/ethanol precipitation, according to standard procedures (Sambrook et al., 1989).

The evaluation of the microsatellite instability was performed by a fluorescent multiplex PCR reaction employing the Bethesda five marker panel (Rodrigues-Bigas et al., 1997; Boland et al., 1998), followed by capillary gel electrophoresis and fragment analysis on the Applied Biosystems' genetic analyzer AbiPrism 310 .

All microsatellite instable cancers were evaluated for their MLH1-promoter methylation status using methylation-specific quantitative $\mathrm{PCR}$ reaction following a bisulfite DNA-conversion (Xiong and Laird, 1997) and tested for the BRAF V600E mutation (Davies et al., 2002), while the corresponding blood DNA samples were screened for large genomic deletions/duplications using the Multiplex Ligation- Dependant Probe Amplification (MLPA) kit reagents from MRC-Holland (Amsterdam, Netherlands) according to the procedure first described by Schouten et al. (2002)

Patients having microsatellite instable cancers without hypermethylated MLH1-promoters and BRAFV600E mutation, lacking large genomic defects but fulfilling the Bethesda criteria for MSI testing, were subjected to bidirectional sequencing of the $M L H 1$ and $M S H 2$ genes using the Applied Biosystems' BigDye Terminator v1.1 Cycle sequencing kit and subsequent sequencing analysis on the AbiPRism310.

For detection of an aberrant mRNA transcript we performed a Reverse transcription-polymerase chain reaction (RT-PCR) using the GeneAmp RNA PCR kit (Life technologies, Califormia, USA) on peripheral mononuclear RNA obtained by the acidic guanidine-phenol-chlorophorm extraction (Chomczynski and Sacchi, 1987).

The detailed conditions for the above reactions and the oligonucleotide sequences of the employed primers are available upon request.

\section{Results and Discussion}

The studied group was comprised of 53 younger patients diagnosed with "Bethesda +"colorectal cancer at an average age of 50 years and progressed mainly to clinical stage B or C. Ovarial, gastic, brain but also breast, hepatic and gall bladder malignancies were identified among the patients or their relatives. Three of these patients were previously diagnosed with endometrial cancer, which is considered one of the commonest extracolonic malignancies in LS, apart from the ovarial cancer (Cruz-Correa and Giardiello, 2002).

The genetic profile of the cancers within this patient group features high frequency of microsatellite instabili- 
ty $(30 \%)$. The comparison with the sporadic CRC cases (Table 1) reveals significant differences in age at diagnosis $(p=0.04)$, involvement of microsatellite instability $(\mathrm{p}<0.0001)$ and tumor localization in respect to flexura lienalis $(p=0.009)$ so that, MSI is 3.99 times more frequently present than MSS in cancers of LS suspects and they develop 2.19 times more frequently in proximal than distal colon, compared to cancers of sporadic cases. These findings comply with the common definitions of the Lynch Sy (Watson and Lynch, 1994; Aarnio et al., 1999), but the published data state an MSI-involvement in $90 \%$ of these cancers. The lower frequency $(30 \%)$ of MSI detected in our cohort, suggests that a significant proportion of these patients are not actually LS-cases but cases with FCC-X. These patients might be having the hereditary syndrome recently proposed by Valle et al. (2007), which is considered a separate entity from LS, featuring MSS tumors, development of colorectal but not other cancers and absence of multiple primary tumors. The vast majority of the hereditary cancers in our group suggest an existence of a yet unidentified gene, being responsible for the development of syndrome, but lacking the MMR activity.

Aiming towards an establishment of a national register of families with hereditary CRC syndromes in our country, we created an interactive computer database of CRC cases, available for access and use by the involved clinicians and laboratory investigators. Additionally, we designed a protocol for molecular confirmation of the LS among clinical suspects for the disease.

The algorithm for detection of MMR defects employed in our study was based on unselective MSI- testing of all CRCs, which had been proven as a cost effective approach in identification of individuals at an increased risk for LS (Palomaki et al., 2009), with a 93\% sensitivity for identification of tumors resulting from MMR-mutations (Shia, 2008). This type of genetic instability was identified among $11 \%$ of all CRCs. A total of 53 patients with "Bethesda+"tumors were subjected to MSI testing. Somatic changes as MMR-promoter hypermethylation and the BRAFV600E mutation are considered as strong negative predictors of MMR-deficiency (Parsons et al., 2012; Bouzourene et al., 2010; Bellizzi and Frankel, 2009) and were

Table 1. Comparison between colorectal cancers of patients fulfilling the Bethesda criteria for LS and sporadic cases.

\begin{tabular}{|c|c|c|c|c|c|}
\hline & $\begin{array}{c}\text { "Bethesda +" CRCs } \\
(\mathrm{n}=53)\end{array}$ & $\begin{array}{c}\text { Sporadic CRCs } \\
(\mathrm{n}=350)\end{array}$ & $\mathrm{M}_{2}-\mathrm{M}_{1}$ & & $\mathrm{p}$ \\
\hline \multicolumn{6}{|l|}{ Age } \\
\hline \multirow[t]{2}{*}{$\begin{array}{l}\text { Number }(\mathrm{n}) \text {, Arithmetical mean } \\
(\mathrm{Ar}) \pm \text { standard deviation }\end{array}$} & $\mathrm{Ar}=50.27 \pm 13.16$ & $\mathrm{Ar}=60.39 \pm 10.78$ & 10.12 & & 0.04 \\
\hline & \multicolumn{2}{|c|}{ Number (frequency) } & OR & $95 \% \mathrm{CI}$ & $\mathrm{p}$ \\
\hline \multicolumn{6}{|l|}{ Gender } \\
\hline $\begin{array}{l}\text { Male } \\
\text { Female }\end{array}$ & $\begin{array}{l}28(0.52) \\
25(0.48)\end{array}$ & $\begin{array}{l}204(0.58) \\
146(0.42)\end{array}$ & 0.80 & \multirow[t]{2}{*}{$0.45-1.43$} & 0.45 \\
\hline \multicolumn{5}{|l|}{ Clinical Tumor Stage } & \\
\hline $\begin{array}{l}\text { A } \\
\text { B } \\
\text { C } \\
\text { D }\end{array}$ & $\begin{array}{c}2(0.06) \\
18(0.56) \\
9(0.28) \\
3(0.09)\end{array}$ & $\begin{array}{c}19(0.06) \\
120(0.41) \\
128(0.43) \\
27(0.09)\end{array}$ & 1.87 & $0.88-3.96$ & $0.09^{\mathrm{a}}$ \\
\hline \multicolumn{6}{|l|}{ Genetic instability } \\
\hline $\begin{array}{l}\text { MSI } \\
\text { MSS }\end{array}$ & $\begin{array}{l}14(0.30) \\
33(0.70)\end{array}$ & $\begin{array}{l}30(0.1) \\
282(0.9)\end{array}$ & 3.99 & $1.92-8.27$ & $<0.0001$ \\
\hline $\begin{array}{l}\text { BRAF V600E + } \\
\text { BRAF V600E - }\end{array}$ & $\begin{array}{l}1(0.02) \\
40(0.98)\end{array}$ & $\begin{array}{c}8(0.04) \\
188(0.96)\end{array}$ & 0.59 & $0.07-4.83$ & 0.61 \\
\hline \multicolumn{6}{|l|}{ Localization } \\
\hline $\begin{array}{l}\text { Proximal }^{\mathrm{b}} \\
\text { Distal }^{\mathrm{c}}\end{array}$ & $\begin{array}{l}23(0.44) \\
29(0.56)\end{array}$ & $\begin{array}{l}77(0.26) \\
213(0.74)\end{array}$ & 2.19 & $1.19-4.02$ & $<0.01$ \\
\hline $\begin{array}{l}\text { Colon } \\
\text { Rectum }\end{array}$ & $\begin{array}{l}35(0.67) \\
17(0.33)\end{array}$ & $\begin{array}{l}188(0.63) \\
109(0.37)\end{array}$ & 1.19 & $0.64-2.23$ & 0.58 \\
\hline
\end{tabular}

${ }^{a}$ comparison between $\mathrm{CRCs}$ of lower $(\mathrm{A}+\mathrm{B})$ and higher stage $(\mathrm{C}+\mathrm{D})$

b Proximal localization includes CRCs localized in the coecum, ascending and transversal colon

${ }^{c}$ Distal localization refers to CRCs localized in the descending colon, sigmoid colon and rectum 
evaluated in all MSI CRCs prior to the MMR-genetic analysis. Patients complying with the revised Bethesda criteria and carrying microsatellite instable tumors without evidence of neither somatic $M L H 1$-promotor hypemethylation nor BRAF-V600E mutation, were selected for genetic testing which included MLPA-analysis for detection of large genomic rearrangements in $M L H 1, M S H 2, P M S 2$ and MSH6 genes, followed by bidirectional DNA-sequencing of the 19 and 16 exons and flanking intronic regions of MLH1 and MSH2 respectively. Using this approach, we narrowed the selected group to 10 patients highly suspicious and suitable for LS-genetic testing. Mutations in the $\mathrm{MSH} 2$ gene were not detected but several genetic defects in $M L H 1$ were identified as most probable causative defects for LS.

We reported previously (Hiljadnikova-Bajro, 2012) the first molecular characterization of the Lynch Syndrome in the Republic of Macedonia by the identification of the nonsense MLH1 c.392C $>$ G mutation in two seemingly unrelated patients, and suspecting its founder effect suggested screening of all LS suspects from the region for this mutation by a Restriction Fragment Length Polymorphism test. Using this approach, we later identified another patient with the same mutation, who has distant familial relationship with one of the abovementioned index patients but wasn't included in the genetic counseling of the patient's family. This case highlights the necessity of presenting a thorough familial history by the patients and in case of identification of a LS patient, genetic counseling of all relatives at risk of cancer development in order to prevent or timely treat it.

Using the MLPA analysis, we detected quantitative changes at either single or multiple nonsuccessive exons in several patients, but these isolated changes probably result from variations within the probes's hybridization loci on the tested DNA leading to impaired hybridization and consequently decreased amplification of the corresponding fragments. But, in one pediatric patient, we detected a large deletion in $M L H 1$ targeting exons 3 through 12 (Fig. 1). The patient is an adolescent boy, diagnosed with two metasynchronous cancers of the transversal and sigmoid colon of stage IIa at the age of 15 and 16 years respectively. The molecular analyses revealed a microsatellite instable character of the cancers, but only one of them was suitable for BRAF and MLH1-hypermethylation testing and scored negative for the BRAF V600E mutation but exerted a high degree of $M L H 1$-promoter methylation. Exploring the familial history of the disease, we concluded that the MLH1genetic defect is most probably inherited from the mother, who was diagnosed with endometrial cancer few years ago. Genetic testing of the mother was offered and if performed in future, it should confirm or exclude this hypothesis. On the other hand, somatic $M L H 1$ promoter hypermethylation is associated with sporadic cases of MSI CRCs, opening a possibility though minor for different etiologies of the two cancers diagnosed in this patient: the first which is currently unavailable for promoter hypermethylaton-testing might be having a hereditary basis, and the other one with hyper-

a)

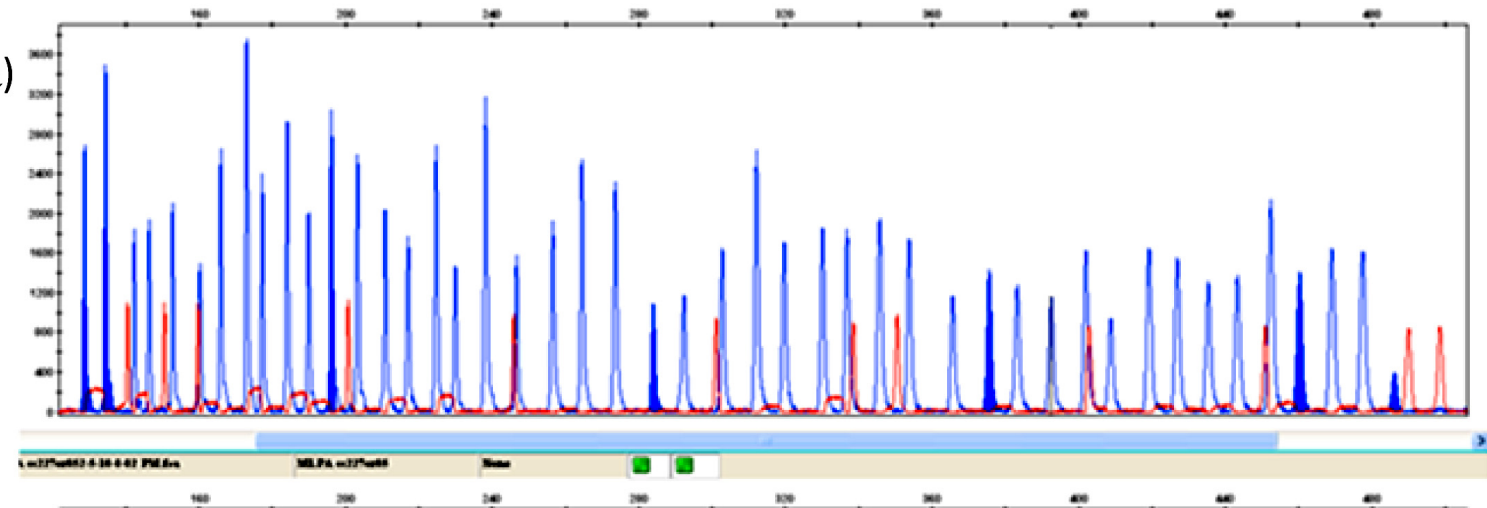

b)

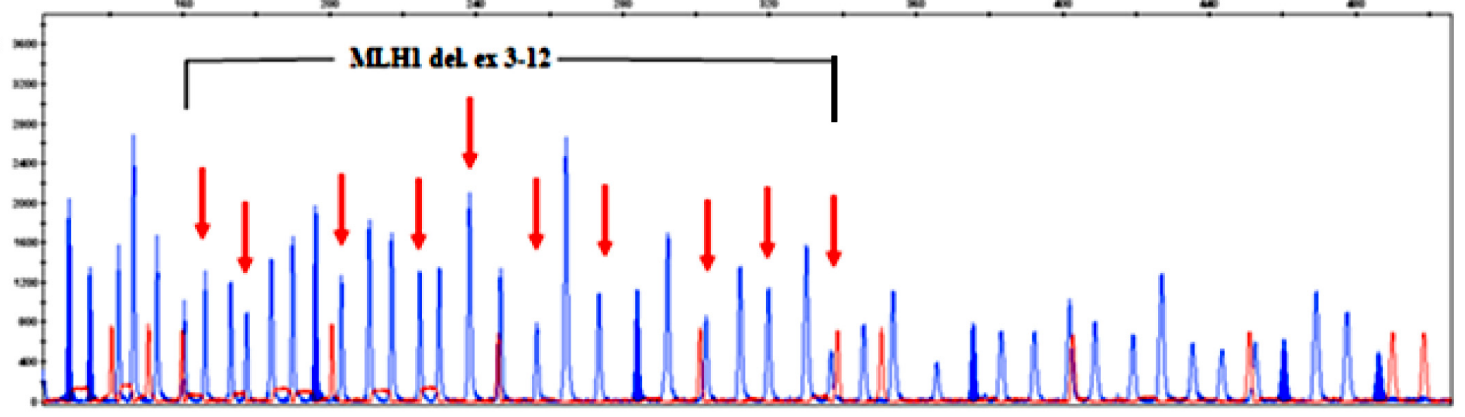

Fig. 1. MLPA-detection of the MLH1 del.ex 3-12 mutation in a patient with the Lynch Syndrome (b) in comparison to a control DNA sample (a). 
$\begin{array}{lllllllllllllllllllllllllllllllllll}\text { A G } & C & T & T & T & T & C & C & T & T & A & A & A & G & T & C & N & C & T & T & C & A & T & T & T & T & T & A & T & T & T & T & C\end{array}$

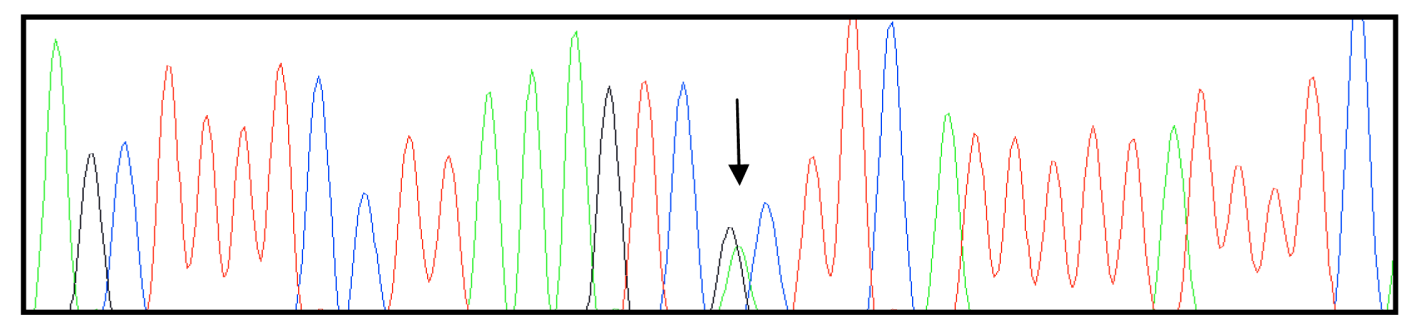

Fig. 2. Electrophoregram corresponding to the sequenced PCR-amplicon of the MLH1 gene in the patient having the mutation IVS14-19A $>$ G

methylated $M L H 1$ promoter could be a sporadic one. But, if MSI and $M L H 1$ promoter hypermethylation are present in both tumors and the genetic testing of the mother confirms the hereditary character of the disease, we might get a strong argument against the hypothesis that somatic promoter hypermethylation of $\mathrm{MLH1}$-gene promoter excludes the Lynch Syndrome diagnosis.

The DNA sequencing-analysis identified a patient with a point DNA-change on the fourteenth intron of $M L H 1$ : IVS14-19A $>$ G (Fig.2), located in the splicing branch site region. This change hasn't been reported in the Human Genome Mutation database (HGMD) as a cause for the Lynch Sy so far. In order to determine the potential impact of this alteration on the posttranscriptional mRNA processing and the existence of an alternative splicing mechanism that would cause production of an aberrant transcript differing in size from the wild type, we performed a RT-PCR reaction on peripheral leukocytes' RNA to achieve reverse transcription and amplification of the investigated region. The obtained DNA-fragment was analyzed by electrophoresis on a $10 \%$ polyacrilamide gel. According to the results presented on the electrophoregram (Fig. 3), we didn't detect an aberrant mRNA-transcript differing in size from the 192bp-long fragments identified among the two wildtype RNA samples. Still, this result doesn't completely exclude the hypothesis for existence of an alternative splicing mechanism due to the IVS14-19A $>$ G mutation. Namely, aberrant mRNA transcripts longer by 17,19 or $20 \mathrm{bp}$ than the wild type ones, might be degraded by the mechanism of nonsense mediated decay and hense become unidentifiable by this test. Therefore, additional functional tests are warranted to confirm/exclude the deleterious effect of this alteration.

In one patient diagnosed with two metachronous CRCs by the age of 40 , burdened with a heavy familial history of cancer, we identified a germline genetic alteration on the fourth $M L H 1$ intron: IVS4+65A>C (Fig.4) which hasn't been previously reported to be involved in the LS, and considering its location within the gene doesn't appear to have a pathological impact. Further genetic testing of MSH6, EPCAM and PMS2 might confirm the LS-association of this cancer or classify it among the FCC-X type CRCs.

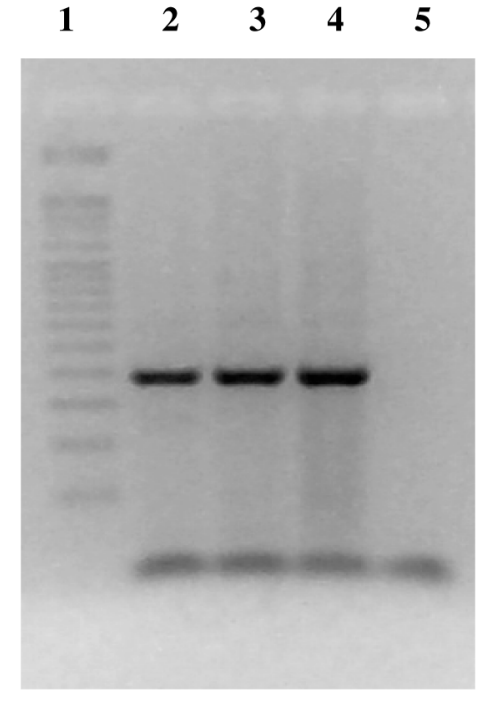

Fig. 3. PAGE electrophoregram of RT-PCR amplicons from: RNA samples corresponding to the patient with the IVS14-19A $>$ G mutation (lane 2) and two control samples (lanes 3 and 4) in comparison to a blank (lane 5) and the molecular size marker StepLadder 50 (lane 1).

We detected the novel missense mutation MLH1 c. $244 \mathrm{~A}>\mathrm{G}, \mathrm{p} . \mathrm{T} 82 \mathrm{~A}$ in one patient diagnosed with a cancer of the ascending colon at an age of 40 , whose mother was also diseased with an early onset CRC. This genetic change leads to a substitution of the polar aminoacid Threonine with the hydrophobic aminoacid Alanine, probably causing a pathogenic effect similar to the c. $245 \mathrm{C}>\mathrm{T}$ mutation already reported in the HGMD.

In $7 / 8$ patients $(87.5 \%)$, we detected the c. $655 \mathrm{~A}>\mathrm{G}$ point mutation in the eighth exon of MLH1 (Fig.5) causing synthesis of a polypeptide with a substitution of Iseleucine with Valine at position 219 (p.Ile219Val). One of these patients holds this genetic variant in a homozygous form, the remaining are being heterozygous. This genetic variation has been previously reported as a polymorphism in the general population (Liu, 1995), but Tomlinson and his col- 
a) TATT T T T T G C C TAGG TCTCA G A G TAATC CT G T CTCA

b)

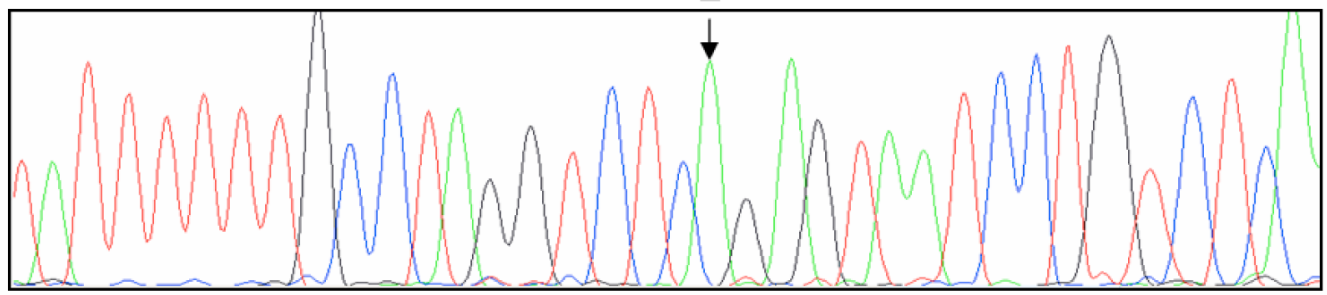

TATT T T TTGCC TAGG TCTCNGAGTAATCCTG TCTCA

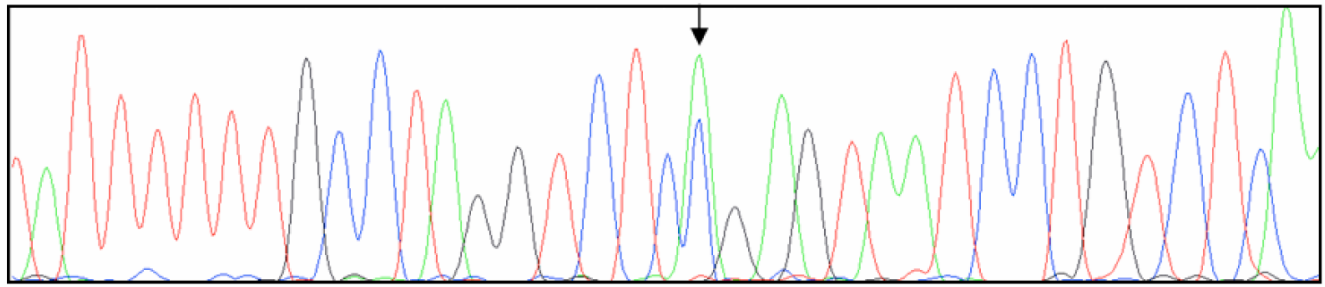

Fig. 4. Electrophoregrams corresponding to a) control genomic DNA and b) DNA sample of a patient with the IVS4+65A $>C$ mutation.

a)

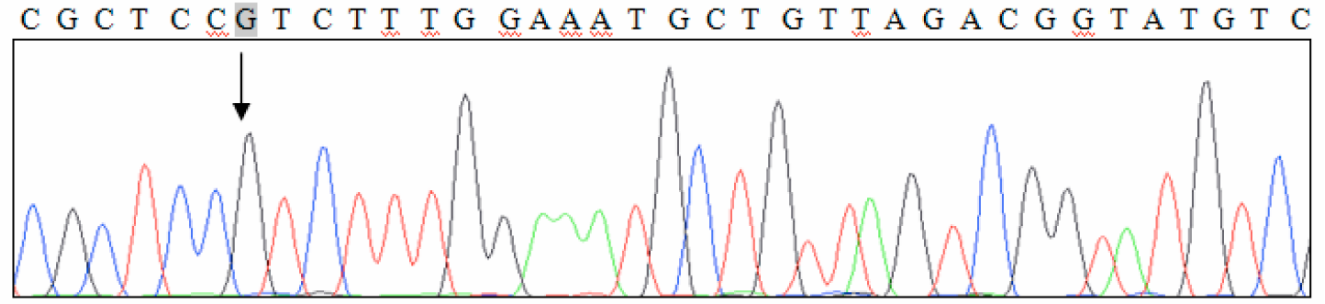

b)

C G C T C C N T C T T T G GAAA T G C T G T T A G A C G G T A T G T C

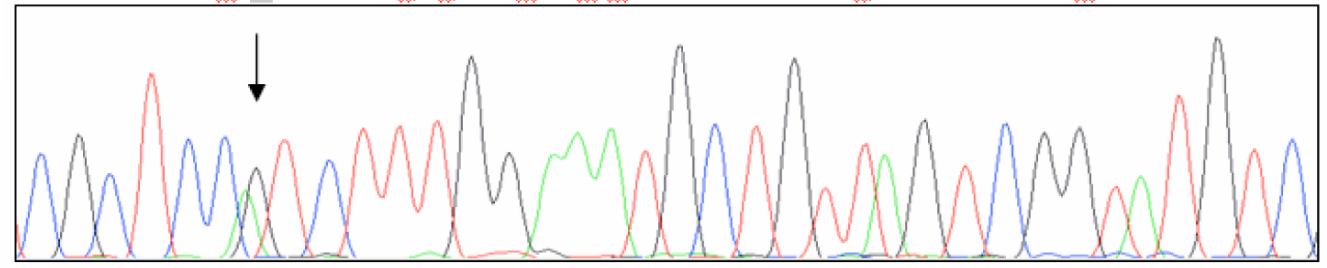

C G C T C CA T C T T T G GAAA T G C T G T T A G A C G G T A T G T C

c)

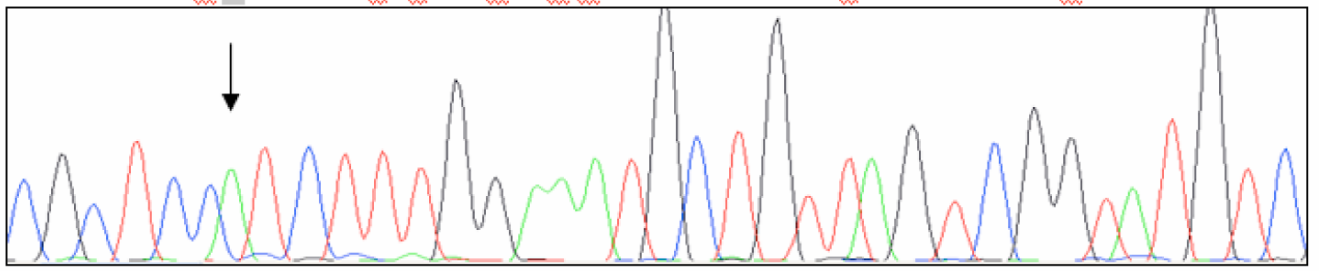

Fig. 5. Detection of the Ile219Val genetic variant in a homozygous (a) and heterozygous (b) form in comparison to a control sample (c).

laborators (Tomlinson et al., 1997) suggest that this change with a frequency of $1 \%$ should be treated as a low penetrant mutation for development of CRC. The Ile219Val change is located in a conserved region of the eighth $M L H 1$ exon, hence it is quite rational to expect its impact on development of pathological consequences. According to the functional analyses performed so far, the products of the wild-type and polymorphic allele poses similar DNAreparative activity (Trojan et al., 2002; Raevaara et al., 2005), but these tests do not address the stability of the proteins which also might be a cause for their impaired activity. Evidence indicating that this change is not totally be- 
nign exist. Some of them even suggesting it to be a predictor of a high mutation frequency haplotype (Hutter et al., 2000, 2002). Furthermore, homozygosity for this variation is associated with reduced expression of the MLH1 protein in sporadic CRCs in Korea (Kim et al., 2004). According to several published studies (Berndt et al., 2007; Yu et al., 2006), Ile219Val is not associated with colonic cancers itself, but the western diet modifies this association in a way that $219 \mathrm{Val} / \mathrm{Val}$ genotype in patients on a western diet (red overroasted meat, fast food, eggs, full-fat dairy products, refined cereals and sugar) is associated with a two-fold increased risk for CRC development in comparison to individuals of the Ile/Ile genotype avoiding the western diet (Campbell, 2009). Additionally, the Ile219Val variant is associated with 5 times higher risk of ulcerative colitis (Bagnoli et al., 2004) which is a risk factor for CRC development itself.

\section{Conclusions}

The molecular profiling of LS among patients with CRC from the Republic of Macedonia has identified the causative deletion MLH1 del.ex3-12 and the novel, possibly founder, nonsense mutation MLH1 c.392C $>$ G and suggests plausible involvement of the c.244A $>\mathrm{G}$ missense mutation, the intronic changes: IVS14-19A $>\mathrm{G}$ and IVS4 $+65 \mathrm{~A}>\mathrm{C}$ as well as the Ile219Val genetic variant within $M L H 1$ in the development of this syndrome. The vast majority of the clinically suspected LS patients are most probably cases with the hereditary syndrome recently proposed by Valle, or cases with a familial cancer of unknown etiology. Focusing the further genetic analyses on these patients might reveal new genes with high or low penetrance for development of colorectal cancer.

\section{References}

Aaltonen, L.A., Salovaara, R., Kristo, P., Canzian, F., Hemminki, A., Peltomaki, P., Chadwick, RB., Kaariainen, H., Eskelinen, M., Jarvinen, H., Mecklin, JP., de la Chapelle, A., 1998. Incidence of hereditary nonpolyposis colorectal cancer and the feasibility of molecular screening for the disease. N. Engl. J. Med. 338(21);1481-1487.

Aarnio, M., Sankila, R., Pukkala, E., Salovaara, R., Aaltonen, LA., de la Chapelle, A., Peltomaki, P., Mecklin, JP., Jarvinen HJ., 1999. Cancer risk in mutation carriers of DNA-mismatchrepair genes. Int. J. Cancer. 81(2):214-218.

Bagnoli, S., Putignano, AL., Melean, G., Baglioni, S., Sestini, R., Milla, M., d'Albasio, G., Genuardi, M., Pacini, F., Trallori, G., Papi, L., 2004. Susceptibility to refractory ulcerative colitis is associated with polymorphism in the hMLH1 mismatch repair gene. Inflamm Bowel Dis. 10(6):705-708.

Bellizzi, AM., Frankel, WL., 2009. Colorectal cancer due to deficiency in DNA mismatch repair function: a review. Adv Anat Pathol. 16:405-417.

Berndt, SI., Platz, EA., Fallin, MD., Thuita, LW., Hoffman, SC., Helzlsouer, KJ., 2007. Mismatch repair polymorphisms and the risk of colorectal cancer. Int. J. Cancer. 120(7):15481554.

Boland, CR., Thibodeau, SN., Hamilton, SR., Sidransky, D., Eshleman, JR., Burt, RW., Meltzer, SJ., Rodriguez-Bigas, MA., Fodde, R., Ranzani, GN., Srivastava, S., 1998. A National Cancer Institute Workshop on Microsatellite Instability for cancer detection and familial predisposition: development of international criteria for the determination of microsatellite instability in colorectal cancer. Cancer Res. 15; 58(22):5248-5257.

Bouzourene, H., Hutter, P., Losi, L., Martin, P., Benhattar, J., 2010. Selection of patients with germline MLH1 mutated Lynch syndrome by determination of MLH1 methylation and BRAF mutation. Fam Cancer. 9:167-172.

Cruz-Correa, M., Giardiello, FM., 2002. Diagnosis and management of hereditary colon cancer. Gastroenterol. Clin. North. Am. 31(2): 537-549.

Campbell, PT., Curtin, K., Ulrich, CM., Samowitz, WS., Bigler, J., Velicer, CM., Caan, B., Potter, JD., Slattery, ML., 2009. Mismatch repair polymorphisms and risk of colon cancer, tumour microsatellite instability and interactions with lifestyle factors. Gut. 58(5): 661-667.

Hiljadnikova-Bajro, M., Josifovski, T., Panovski, M., Dimovski, AJ., 2012. A novel germline MLH1 mutation causing Lynch Syndrome in patients from the Republic of Macedonia. Croat Med J. 53 (5):496-501. http://www.hgmd.cf.ac.uk/ac/index. php assessed at 18.05.2012

Jasperson, KW., Tuohy, TM., Neklason, DW., Burt, RW., 2010. Hereditary and familial colon cancer. Gastroenterology. 138(6):2044-2058

Jass, JR., 2006. Hereditary Non-Polyposis Colorectal Cancer: the rise and fall of a confusing term. World J. Gastroenterol. 12(31):4943-4950.

Kim, JC., Roh, SA., Koo, KH., Ka, IH., Kim, HC., Yu, CS., Lee, KH., Kim, JS., Lee, HI., Bodmer, WF., 2004. Genotyping possible polymorphic variants of human mismatch repair genes in healthy Korean individuals and sporadic colorectal cancer patients. Fam Cancer. 3(2):129-137.

Lindor, NM., Rabe, K., Petersen, GM., Haile, R., Casey, G., Baron, J., Gallinger, S., Bapat, B., Aronson, M., Hopper, J., Jass, J., LeMarchand, L., Grove, J., Potter, J., Newcomb, P., Terdiman, JP., Conrad, P., Moslein, G., Goldberg, R., Ziogas, A., Anton-Culver, H., de Andrade, M., Siegmund, K.., Thibodeau, SN., Boardman, LA., Seminara, D., 2005. Lower cancer incidence in Amsterdam-I criteria families without mismatch repair deficiency: familial colorectal cancer type X. JAMA293(16):1979-1985.

Liu, B., Nicolaides, NC., Markowitz, S., Willson, JK., Parsons, RE., Jen, J., Papadopolous, N., Peltomäki, P., de la Chapelle, A., Hamilton, SR., Kinzler, KW., Vogelstein, B., 1995. Mismatch repair gene defects in sporadic colorectal cancers with microsatellite instability. Nat. Genet. 9(1): 48-55.

Llor, X., Pons, E., Xicola, RM., Castells, A., Alenda, C., Piñol, V., Andreu, M., Castellví-Bel, S., Payá, A., Jover, R., Bessa, X., Girós, A., Roca, A., Gassull, MA., 2005. Gastrointestinal Oncology Group of the Spanish Gastroenterological Association. Differential features of colorectal cancers fulfilling Amsterdam criteria without involvement of the mutator pathway. Clin. Cancer. Res.11(20):7304-7310.

Mueller-Koch, Y., Vogelsang, H., Kopp, R., Lohse, P., Keller, G., Aust, D., Muders, M., Gross, M., Daum, J., Schiemann ,U., Grabowski, M., Scholz, M., Kerker, B., Becker, I., Henke, G., Holinski- Feder, E., 2005. Hereditary non-polyposis 
colorectal cancer: clinical and molecular evidence for a new entity of hereditary colorectal cancer. Gut. 54(12):17331740.

National Cancer Institute, Genetics of Colorectal Cancer (PDQ), Health Professional Version, last modified 2012, assessed at 18.05.2011; http://www.cancer.gov/cancertopics/pdq/ genetics/colorectal/HealthProfessional

Palomaki, GE., McClain, MR., Melillo, S., Hampel, HL., Thibodeau, SN., 2009. EGAPP supplementary evidence review: DNA testing strategies aimed at reducing morbidity and mortality from Lynch syndrome. Genet Med. 11(1):4265 .

Parsons, MT., Buchanan, DD., Thompson, B., Young, JP., Spurdle, AB., 2012. Correlation of tumour BRAF mutations and MLH1 methylation with germline mismatch repair (MMR) gene mutation status: a literature review assessing utility of tumour features for MMR variant classification. J. Med. Genet. 49(3):151-157

Raevaara, TE., Korhonen, MK., Lohi, H., Hampel, H., Lynch, E., Lönnqvist, KE., Holinski-Feder, E., Sutter, C., McKinnon, W., Duraisamy, S., Gerdes, AM., Peltomäki, P., KohonenCcorish, M., Mangold, E., Macrae, F., Greenblatt, M., de la Chapelle, A., Nyström, M., 2005. Functional significance and clinical phenotype of nontruncating mismatch repair variants of MLH1. Gastroenterology 129(2):537-549.

Risinger, J.I., Barrett, J.C., Watson, P., Lynch, H.T., Boyd, J., 1996. Molecular genetic evidence of the occurrence of breast cancer as an integral tumor in patients with the hereditary nonpolyposis colorectal carcinoma syndrome. Cancer. 77(9):1836-1843.

Rodriguez-Bigas, MA., Boland, CR., Hamilton, SR., Henson, DE., Jass, JR., Khan, PM., Lynch, H., Perucho, M., Smyrk, T., Sobin, L., Srivastava, S., 1997. A National Cancer Institute Workshop on Hereditary Nonpolyposis Colorectal Cancer Syndrome: meeting highlights and Bethesda guidelines. J. Natl. Cancer Inst. 89(23):1758-1762.

Sambrook, J., Fritsch, EF., Maniatis, T., 1989. Molecular Cloning - A Laboratory Manual, $2^{\text {nd }}$ Edition. Cold Spring Habour Laboratory Press, New York.

Schouten, JP., McElgunn, CJ., Waaijer, R., Zwijnenburg, D., Diepvens, F., Pals, G., 2002. Relative quantification of 40 nucleic acid sequences by multiplex ligation-dependent probe amplification. Nucleic Acids Res. 30(12):e57.
Shia J., 2008. Immunohistochemistry versus microsatellite instability testing for screening colorectal cancer patients at risk for hereditary nonpolyposis colorectal cancer syndrome. Part 1: The utility of immunohistochemistry. J. Mol. Diagn. 10: 293-300.

Tomlinson, IP., Beck, NE., Homfray, T., Harocopos, CJ., Bodmer, WF., 1997. Germline HNPCC gene variants have little influence on the risk for sporadic colorectal cancer. J. Med. Genet. 34(1):39-42.

Trojan, J., Zeuzem, S., Randolph, A., Hemmerle, C., Brieger, A., Raedle, J., Plotz, G., Jiricny, J., Marra, G., 2002. Functional analysis of hMLH1 variants and HNPCC-related mutations using a human expression system. Gastroenterology 122(1): 211-219.

Umar, A., Boland, CR., Terdiman, JP., Syngal, S., de la Chapelle, A., Ruschoff, J., Fishel, R., Lindor, NM., Burgart, LJ., Hamelin, R., Hamilton, SR., Hiatt, RA., Jass, J., Lindblom, A., Lynch, HT., Peltomaki, P., Ramsey, SD., RodriguezBigas, MA., Vasen, HF., Hawk, ET., Barrett, JC., Freedman, AN., Srivastava, S., 2004. Revised Bethesda Guidelines for hereditary nonpolyposis colorectal cancer (Lynch syndrome) and microsatellite instability. J. Natl. Cancer Inst. 96(4):261268.

Valle, L., Perea, J., Carbonell, P., Fernandez, V., Dotor, AM., Benitez, J., Urioste, M., 2007. Clinicopathologic and pedigree differences in Amsterdam I-positive hereditary nonpolyposis colorectal cancer families according to tumor microsatellite instability status. J. Clin. Oncol. 25(7):781-786.

Vasen, HF., Mecklin, JP., Khan, PM., Lynch, HT., 1991. The International Collaborative Group on Hereditary NonPolyposis Colorectal Cancer (ICG-HNPCC). Dis Colon Rectum. 34(5):424-425.

Vasen, HF., Mecklin, JP., Khan, PM., Lynch, HT., 1994. The International Collaborative Group on HNPCC. Anticancer Res. 14(4B):1661-1664

Watson, P., Lynch, HT., 1994. The tumor spectrum in HNPCC. Anticancer Res. 14(4B):1635-1639. Xiong, Z., Laird, PW., 1997. COBRA: a sensitive and quantitative DNA methylation assay. Nucleic Acids Res. 25(12):2532-2534.

Yu, JH., Bigler, J., Whitton, J., Potter, JD., Ulrich, CM., 2006. Mismatch repair polymorphisms and colorectal polyps: hMLH1-93G $>$ A variant modifies risk associated with smoking. Am. J. Gastroenterol. 101(6):1313-1319. 


\title{
Резиме
}

\section{Молекуларен профил на Линч Синдромот во Република Македонија}

\author{
Марија Хиљадникова-Бајро', Тони Јосифовски², Милчо Пановски², \\ Александар Ј. Димовски ${ }^{3 *}$ \\ ${ }^{1}$ Институт за применета биохемија, Фармацевтски факултет, Универзитет „Св. Кирил и Методиј“, Скопје, \\ Република Македонија \\ ${ }^{2}$ Универзитетска клиника за дигестивна хирургија, Медицински факултет, Универзитет „Св. Кирил и Методиј“, \\ Скопје, Република Македонија \\ $3^{3 *}$ Центар за биомолекуларни фармацевтски анализи, Фармацевтски факултет, Универзитет „Св. Кирил и \\ Методиј“, Скопје, Република Македонија
}

Клучни зборови: Колоректален карцином, Линч синдром, $M L H 1$, микросателитска нестабилност

Најзастапениот тип на наследен колоректален карцином, карактеристичен за Линч синдромот (ЛС), се смета за фенотипска манифестација на генетски дефект во механизмот за репарација на несоодветно спарување на бази при ДНК репликација, односно во MLH1, MSH2, MSH6 или PMS2 генот. Во рамките на нашите напори за воспоставување на стандардизиран протокол што ќе вклучува молекуларни анализи за дијагноза на овој синдром и формирање на единствен национален регистер на семејства со наследни синдроми на колоректален карцином во Република Македонија, отпочнавме проспективна студија за разоткривање на генетските дефекти кај Македонските пациенти со колоректален карцином (КРК) и идентификација на семејства со наследен КРК.

Вкупно 53 пациенти кои ги исполнуваат ревидираните Бетезда критериуми за генетско тестирање за Линч синдромот беа споредени со 350 пациенти со спорадичен КРК. Резултатите покажуваат сигнификанти разлики во однос на возраста при дијагноза $(\mathrm{p}=0,03)$, инволвираност на микросателитската нестабилност $(\mathrm{p}<0,001)$ и локализација на туморот во однос на flexura lienalis $(\mathrm{p}=0,009)$ и сугерираат припадност на повеќето од „Бетезда+““ КРКи кон групата позната како Фамилијарен Колоректален карцином од тип „X“. Со молекуларната карактеризација на ЛС-суспектите идентификувавме нова MLH1 c.392C>G nonsense мутација со потенцијален „founder“ ефект кај Македонската популација и MLH1 ех.3-12 делецијата, како и с.244 A>G мутацијата, IVS14$19 \mathrm{~A}>\mathrm{G}$ и IVS4+65A>C промените без потврдено патолошко значење. Високата фреквенција (87.5\%) на Ile219Val (c.655A>G) варијантата во $M L H 1$ забележана кај ЛС суспектите ја наложува потребата од дополнителни аналзи за евалуирање на нејзината инволвираност во развојот на наследен КРК како самостоен ризик фактор или модификатор на ризикот кај пациентите од Република Македонија. 



\title{
Frequency of the most common CYP3A5 polymorphisms in the healthy population of the Republic of Macedonia
}

\author{
Krume Jakovski ${ }^{1}$, Aleksandra Kapedanovska Nestorovska ${ }^{2}$, Nikola Labacevski ${ }^{1}$, \\ Aleksandar J. Dimovski* \\ ${ }^{1}$ Department of Preclinical and Clinical Pharmacology and Toxicology, Faculty of Medicine, \\ University "Ss Cyril and Methodius", Skopje, Republic of Macedonia \\ ${ }^{2}$ Center for Bimolecular and Pharmaceutical Analysis, Faculty of Pharmacy, \\ University "Ss Cyril and Methodius", Skopje, Republic of Macedonia
}

Received: June 2012; Accepted: August 2012

\begin{abstract}
The genetic polymorphism affecting the CYP3A5 enzyme is responsible for inter-individual and interethnic variability in the metabolism of CYP3A 5 substrates. The aim of this study was to analyze the distribution of the most common CYP3A $5 * 3$ allelic variants in the healthy population of R. Macedonia and to investigate if the allelic frequency falls within the assumed range for European Caucasians. The total of 174 healthy volunteers from the general population were included. The genotyping of the CYP3A5*3 variant alleles, *3A (rs 15524 ) and *3E (rs28365095), was performed with Real-Time PCR based on the allelic discrimination method using a TaqMan SNP genotyping assay according to the manufacturer's instructions. The CYP3A5*3 allele is abundantly present displaying an allelic frequency of 0.922 . We estimate that 0.82 of the Macedonian population are homozygotes for the variant and do not have a CYP3A5 enzymatic activity.

Our study demonstrated a high prevalence of CYP3A $5 * 3$ allele in the Macedonian population. The distribution of CYP3A5 alleles was similar to that found in other European Caucasians. As the goals of personalized medicine are beginning to be realized, this provides basic information on the CYP3A5 allele frequency for the future pharmacogenetic research in R. Macedonia.
\end{abstract}

Key words: allelic variants, CYP3A5, population frequency, R. Macedonia

\section{Introduction}

Isoforms of the cytochrome P450 (CYP) 3A subfamily are the most abundantly expressed CYP enzymes in the human liver. They participate in the metabolism of endogenous compounds, bile acids and steroids (such as aldosterone, testosterone, and estrogens), but also in the biotransformation of approximately $50 \%$ of the currently marketed drugs (steroids, antidepressants, immunosuppressive agents and antibiotics) (Paine et al., 2006).

Substantial inter-individual differences in the CYP3A enzyme expression contribute to the divergence in oral bioavailability and systemic clearance of CYP3A substrates.

\footnotetext{
*adimovski@ff.ukim.edu.mk

tel/fax:++38923126054
}

Estimates of the relative involvement of a genetic variation relevant to the CYP3A function indicate that 70 to $90 \%$ of inter-individual variability is attributable to genetic factors (He et al., 2006).

The CYP3A gene family consists of four genes $(C Y-$ $P 3 A 4, C Y P 3 A 5, C Y P 3 A 7$, and CYP3A43) clustered in a region of about $220 \mathrm{~kb}$ in chromosome 7q21 (Kuehl et al., 2001; Garsa et al., 2005). In human adults, CYP3A4 and CYP3A5 are the predominant functional CYP3A isoforms. Although single nucleotide polymorphisms (SNPs) have been found in the coding region of CYP3A4, they are rare and appear to have limited impact on CYP3A4 and the total CYP3A activity. CYP3A5 is the primary extrahepatic CYP3A isoform and typically displays a decreased catalytic activity compared to CYP3A4. So far, 13 genetic polymorphisms have been described for CYP3A5 (Huang et al., 2004). The genetic basis for polymorphically expressed CYP3A5 has been associated with SNP in intron 3 of the 
CYP3A5 gene (CYP3A5*3C; g.6986A>G) (King et al., 2003). CYP3A5*3C mutant allele is the major defective allele, leading to alternative splicing and protein truncation, which in turn results in the absence of the enzyme activity. This variant is the only one reported in all ethnic groups and is therefore considered the most ancient allele. SNPs in the $3{ }^{\prime} \mathrm{UTR}$ (CYP3A5*3A, g. 31611C>T) and in the intron $10(\mathrm{CYP} 3 \mathrm{~A} 5 * 3 \mathrm{U}$, g. $27050 \mathrm{~A}>\mathrm{G})$ of the CY$\mathrm{P} 3 \mathrm{~A} 5$ gene occur in a tight linkage disequilibrium with the CYP3A $5 * 3 \mathrm{C}$ variant. All of these linkages cause functionally defective alleles (Bussi and Createil., 2005; Lakhman et al., 2009). Because CYP3A5 represents at least 50\% of the total hepatic CYP3A content in people polymorphically expressing CYP3A5, it may be the most important genetic contributor to inter-individual and interracial differences in CYP3A-dependent drug clearance and in responses to many medicines (Kuehl et al., 2001). The relevance of CYP3A5 genotyping will depend on the contribution of this enzyme to the total CYP3A-mediated metabolism of a specific drug. For many drugs, this contribution is not exactly known (Huang et al., 2004).

The frequency of the most common $C Y P 3 A 5 * 3$ variant alleles differs among populations and races, ranging from $27-50 \%$ in the African-American population, $60-70 \%$ among Asians, and up to $85-95 \%$ in individuals of Cauca- sian ancestry, in which the expresser variant (CYP3A $5 * 1)$ is uncommon (Park et al., 2008; Coto et al., 2010; Gebeyehu et al., 2011). In addition to the diverse $C Y P 3 A 5 * 3$ frequency across human populations, there are remarkable ethnic-related differences with regard to the frequency of CYP3A5 variants, with an excess of rare variants (Thompson et al., 2004; Sinues et al., 2007; Azarpira et al., 2011). There has been no detailed allele and diplotype analysis of the most common CYP3A5 genetic variant in the Macedonian population.

The objective of this study was therefore to analyze the distribution of the most common CYP3A5 allelic variants in the healthy population of R. Macedonia and to investigate if the allelic frequency falls within the assumed range for European Caucasians.

\section{Materials and methods}

\section{Study population and DNA isolation}

After receiving informed consent, we obtained EDTA whole blood from 194 unrelated healthy donors of a Caucasian origin who self-reported as ethnic Macedonians. Genomic DNA was isolated using Proteinase K digestion, phenol chloroform extraction and ethanol precipita-

Table 1. Genotype distribution of the tested variants in a healthy population of R. Macedonia $(\mathrm{N}=174)^{*}$

\begin{tabular}{|c|c|c|c|c|c|}
\hline CYP3A5 variant & & & $\mathrm{n}^{* *}$ & Observed frequency & $\begin{array}{c}\text { Predicted frequency by } \\
\text { HW eq. }\end{array}$ \\
\hline \multirow{3}{*}{$\begin{array}{c}\text { CYP3A5*3A } \\
(31611 \mathrm{C}>\mathrm{T})\end{array}$} & $\mathrm{CC}$ & $* 1 / * 1$ & 2 & 0.011 & 0.008 \\
\hline & $\mathrm{CT}$ & $* 1 / * 3 \mathrm{~A}$ & 28 & 0.161 & 0.167 \\
\hline & TT & $* 3 \mathrm{~A} / * 3 \mathrm{~A}$ & 144 & 0.828 & 0.825 \\
\hline \multirow{3}{*}{$\begin{array}{l}\text { CYP3A5*3E } \\
(27050 A>G)\end{array}$} & $\mathrm{AA}$ & $* 1 / * 1$ & 132 & 0.759 & 0.758 \\
\hline & $\mathrm{AG}$ & $* 1 / * 3 \mathrm{E}$ & 39 & 0.224 & 0.225 \\
\hline & GG & $* 3 \mathrm{E} / * 3 \mathrm{E}$ & 3 & 0.017 & 0.017 \\
\hline
\end{tabular}

$* \mathrm{~N}$ - total number of subjects in study

** number of subjects

Table 2. Diplotype analysis of CYP3A5*3 allelic variants in Macedonian population.

\begin{tabular}{|c|c|c|c|c|c|c|}
\hline $\begin{array}{c}\text { CYP3A5*3 Diplotype } \\
\text { analysis }\end{array}$ & $31611 \mathrm{C}>\mathrm{T}$ & $27050 A>G$ & $\mathrm{n}$ & Total & $\begin{array}{l}\text { Observed } \\
\text { frequency }\end{array}$ & $\begin{array}{l}\text { Predicted frequency } \\
\text { by HW eq. }\end{array}$ \\
\hline$* 1 / * 1$ & $\mathrm{CC}$ & AA & 2 & 2 & 0.011 & 0.006 \\
\hline \multirow{2}{*}{$* 1 / * 3$} & $\mathrm{CC}$ & $\mathrm{AG}$ & 0 & \multirow{2}{*}{23} & \multirow{2}{*}{0.132} & \multirow{2}{*}{0.143} \\
\hline & $\mathrm{CT}$ & GG & 23 & & & \\
\hline \multirow{4}{*}{$* 3 / * 3$} & $\mathrm{CT}$ & AG & 5 & \multirow{4}{*}{149} & \multirow{4}{*}{0.856} & \multirow{4}{*}{0.851} \\
\hline & TT & AA & 107 & & & \\
\hline & TT & AG & 34 & & & \\
\hline & TT & GG & 3 & & & \\
\hline
\end{tabular}


tion. DNA yields and purity were estimated by measuring the absorbance at $260 \mathrm{~nm}$ and $260 / 280 \mathrm{~nm}$, respectively [NanoDrop 2000, Thermo Scientific] and DNA integrity was confirmed with electrophoresis in $0,8 \%$ agarose gels, stained with ethidium bromide. The Ethical Committee of the Ministry of Health of R. Macedonia approved the study. All personal identifiers were removed and the isolated DNA samples were tested anonymously.

\section{Genotyping procedures}

The designations of all CYP450 alleles refer to those defined by the Cytochrome P450 Allele Nomenclature Committee (http://www.cypalleles.ki.se/). The genotyping of the CYP3A5*3 variant alleles, *3A (rs15524) and *3E (rs28365095), was performed with Real-Time PCR based on the allelic discrimination method [MxPro 3005P, Stratagene, La Jolla, CA, USA] using a TaqMan SNP genotyping assay according to the manufacturer's instructions [Applied Biosystems, Foster City, CA, USA].

\section{Statistical Analysis}

All statistical analyses were performed using the SISA statistical platform. Observed genotype distributions were assessed for the Hardy-Weinberg equilibrium with a $X^{2}$ test. Frequency analyses of an inter-population diversity of the examined polymorphisms were performed on data reported for apparently healthy control populations from several different geographic regions in Europe. The difference in CYP3A5 allelic frequencies between our and other ethnic populations was evaluated using the Chi-squared analysis and Fishers Exact Test. Odds ratios [OR] were calculated with $95 \%$ confidence limits [ $95 \% \mathrm{CI}]$. Factors with $\mathrm{p} \leq 0.05$ were considered statistically significant.

\section{Results}

Genotyping for the CYP3A5*3 allele, CYP3A5*3A (g.31611 C>T) and CYP3A5*3E (g. $27050 \mathrm{~A}>\mathrm{G})$, was successively performed in the total of 174 subjects. The genotype distribution of the CYP3A5*3 variants is summarized in Table 1. Table 2 shows the results of the diplotype analyses. The frequency distributions were consistent with the Hardy-Weinberg equilibrium $(P>0.05)$, indicating that the volunteer pool in this study was likely a representative sample of the population being studied.

Table 3. The CYP3A5*3 allele frequencies in the population of R.Macedonia

\begin{tabular}{ccc}
\hline \hline CYP3A5 polymorphism & Variant allele & $\begin{array}{c}\text { Allele Frequency } \\
(\text { na }=348) *\end{array}$ \\
\hline $31611 \mathrm{C}>\mathrm{T}$ & CYP3A5*3A & 0.908 \\
$27050 \mathrm{~A}>\mathrm{G}$ & CYP3A5*3E & 0.129 \\
$31611 \mathrm{C}>\mathrm{T}+27050 \mathrm{~A}>\mathrm{G}$ & $\mathrm{CYP3A} 5 * 3$ & 0.922 \\
\hline *na - total number of alleles & &
\end{tabular}

The CYP3A5*3A allele was found in 172 subjects with an allelic frequency of 0.908 , while CYP $3 \mathrm{~A} 5 * 3 \mathrm{E}$ was found in 42 subjects with an allelic frequency of 0.129 . Overall, the frequency of the CYP $3 \mathrm{~A} 5 * 3$ diplotype was estimated at 0.922 (Table 3). The CYP3A5*3 variant allele frequency in the healthy population of R. Macedonia com-

Table 4. Allele Frequencies of the CYP3A5*3 variant observed in this study compared with those found in other European ethnic groups

\begin{tabular}{cccccl}
\hline \hline Ethnic group & $\begin{array}{c}\mathrm{N} \\
\text { (study sub- } \\
\text { jects) }\end{array}$ & $\begin{array}{c}\mathrm{n} \\
\text { (total alleles) }\end{array}$ & $\begin{array}{c}\text { CYP3A5*3 allele frequency } \\
* 1\end{array}$ & $* 3$ & \multicolumn{1}{c}{ Reference } \\
\cline { 3 - 5 } R.Macedonia & 174 & 348 & 0.078 & 0.922 & present study \\
Greece & 283 & 566 & 0.057 & 0.943 & Avrantidis et al., 2007 \\
Poland & 200 & 400 & 0.06 & 0.94 & Adler et al., 2009 \\
Belgian & 50 & 100 & 0.06 & 0.94 & Haufroidet al., 2004 \\
Russia & 196 & 392 & 0.06 & 0.94 & Seredina et al.,2012 \\
Germany & 428 & 856 & 0.061 & 0.939 & Dally et al., 2004 \\
Bosnia and Herzegovina & 139 & 278 & 0.068 & 0.932 & Semiz et al., 2011 \\
Italy & 50 & 100 & 0.07 & 0.93 & Turolo et al., 2010 \\
Sweeden & 136 & 272 & 0.07 & 0.93 & Mirghani et al., 2006 \\
Finland & 449 & 898 & 0.079 & 0.921 & Hilli et al., 2007 \\
Netherlands & 500 & 1000 & 0.083 & 0.917 & Van Schauk et al., 2002 \\
Netherlands & 500 & 1000 & 0.07 & 0.914 & Vaarala et al., 2008 \\
Spain & 177 & 354 & 0.09 & 0.91 & Gervasini et al., 2005 \\
Great Britain & 133 & 266 & 0.11 & 0.89 & King et al., 2003 \\
France & 149 & 298 & 0.13 & 0.81 & Quaranta et al., 2006 a \\
\hline
\end{tabular}


pared to data reported from various ethnic groups with European ancestry are presented in Table 4.

\section{Discussion}

Various ethnic groups show different frequencies of CYP450 allelic variants, probably due to ancient migrations of geographically distinct and isolated human groups, combined with the influences of selective factors, such as diet or disease (Lee et al., 2003).

Inter-individual variability in the clearance of CYP3A substrates can result from the effects of inducers, inhibitors, or genetic or dietary factors that potentially lead to differences in drug toxicity and response. According to the published data, CYP3A5 activity varies within any given ethnic population, suggesting that the genetic variation within the CYP3A5 gene may be the most important contributor to inter-individual and interracial differences in CYP3A-dependent drug clearance and response (Makeeva et al., 2008). CYP $3 A 5^{*} 1$ is the only $C Y P 3 A 5$ allele to date that produces high levels of full-length $C Y$ $P 3 A 5$ mRNA and expresses $C Y P 3 A 5$ while the more common $C Y P 3 A 5$ polymorphism in Caucasians, $C Y P 3 A 5^{*} 3$, produces an aberrantly spliced mRNA with a premature stop codon. Marked interethnic differences have been reported for the CYP3A5*3 allelic variant (Roy et al., 2005; Quaranta et al., 2006b).

The present study documents the distribution of CYP3A $5 * 3$ in a population of $\mathrm{R}$. Macedonia. The $C Y P 3 A 5^{*} 3$ allele was abundantly present in the subjects of our study, with an allelic frequency of 0.922 . We observed no statistically significant difference $(\mathrm{p}>0.05)$ compared to CYP3A5*3 frequency data reported for other European ethnic groups. The frequency of the CYP3A $5 * 3$ variant allele in our population was interpolated between 0.94 in Greece, Poland, Belgium, Russia and Germany; 0.93 in Bosnian and Herzegovina, Italy and Sweden; 0.92 in Finland, 0.91 in Netherlands, Spain and Croatia; 0.89 in Great Britain and 0.81 in France. This is in good concordance with the described trend of the increasing gradient of $C Y P 3 A 5^{*} 1$ allele frequency from north to south of the globe (Suarez-Kurtz et al., 2007).

The CYP3A5*3 homozygotes lack CYP3A5 expression (non expressors) and are associated with a phenotype of decreased metabolic capacity. Conversely, in individuals with at least one $C Y P 3 A 5^{*} 1$ wild type allele, CYP3A5 accounts for at least $50 \%$ of the total CYP3A content, and results in a 2- to 3-fold higher total CYP3A catalityc activity (Zeigler-Johnson et al., 2004; Press et al., 2009) . This expression variability might be an explanation for the differences in dose requirements in patients who are treated with drugs that are cleared by CYP3A5; CYP $3 A 5^{*} 3$ homozygotes would require a lower dose of the drug to reach the blood concentration target, compared to CYP $3 A 5 * 1$ homozygotes (Solas et al., 2007; Roco et al., 2012). However, although several studies have attempted to correlate the metabolic capabilities of different patients with the genotype, a clear relationship between the levels of CYP3A5 expression and/or activity and genetic markers remains to be established (Wang et al., 2012).

In the studied population of 174 subjects, $0.011(\mathrm{n}=$ 2) were homozygous for the $* 1$ allele, $0.856(\mathrm{n}=149)$ for the $* 3$ allele, and $0.132(\mathrm{n}=23)$ were $* 1 / * 3$ heterozygotes. Since heterozygotes for $C Y P 3 A 5 * 3$ may have some CYP3A5 activity, we estimate that 0.86 of the Macedonian population do not have a CYP3A5 enzymatic activity. This is in agreement with the finding that $10 \%$ of the Caucasians were high expressers of CYP3A5 (Van Schaik et al., 2002).

Several lines of evidence suggest that the distribution of CYP3A5 genetic variants in people living in the developing countries may differ from that of people living in industrialized countries due to the selection pressure exerted on specific alleles by different environmental factors present in these geographic areas. To date, most studies on the Cyp3A5 polymorphism have been conducted in populations from industrialized countries (Roy et al., 2005).

Since no data were available for the Macedonian ethnic group, we would like to emphasize the value of these results, which may serve as a background for comparison with other population samples and could be included in case-control studies as a reference.

\section{Conclusion}

Our study demonstrated the high prevalence of CYP3A5*3 allele in the Macedonian population. The distribution of $C Y P 3 A 5$ alleles was similar to that found in other European Caucasians. As the goals of personalized medicine are beginning to be realized, this provides basic information on the CYP3A5 allele frequency for the future pharmacogenetic research in R. Macedonia.

\section{References}

Adler, G., Łoniewska, B., Parczewski, M., Kordek,A., Ciechanowicz, A., 2009. Frequency of common CYP3A5 gene variants in healthy Polish newborn infants. Pharmacol Rep 61, 947-951.

Arvanitidis, K., Ragia, G., Iordanidou, M., Kyriaki, S., Xanthi, A., Tavridou, A., Manolopoulos, V.G., 2007. Genetic polymorphisms of drug-metabolizing enzymes CYP2D6, CYP2C9, CYP2C19 and CYP3A5 in the Greek population. Fundam Clin Pharmacol 21, 419-426.

Azarpira, N., Namazi, S., Khalili, A., Tabesh, M., 2011. The investigation of allele and genotype frequencies of CYP3A5 (1/3) and P2Y12 (T744C) in Iran. Mol. Biol. Rep. 38, 4873-4877.

Busi, F., Cresteil, T., 2005. CYP3A5 mRNA degradation by nonsensemediated mRNA decay. Mol. Pharmacol. 68, 808-815.

Coto, E., Tavira, B., Marín, R., Ortega, F., López-Larrea, C., Ruiz-Ortega, M., Ortiz, A., Díaz, M., Corao, A.I., Alonso, B., Alvarez, V., 2010. Functional polymorphisms in the CYP3A4, CYP3A5, and CYP21A2 genes in the risk for hypertension in pregnancy. Biochem. Biophys. Res. Commun. 397, 576-579. 
Dally, H., Bartsch, H., Jäger, B., Edler, L., Schmezer, P., Spiegelhalder, B., Dienemann, H., Drings, P., Kayser, K., Schulz, V., Risch, A., 2004. Genotype relationships in the CYP3A locus in Caucasians. Cancer Lett. 207, 95-99.

Garsa, A.A., McLeod, H.L., Marsh, S., 2005. CYP3A4 and CYP3A5 genotyping by Pyrosequencing. BMC Med. Genet. 6, 19.

Gebeyehu, E., Engidawork, E., Bijnsdorp, A., Aminy, A., Diczfalusy, U., Aklillu, E., 2011. Sex and CYP3A5 genotype influence total CYP3A activity: high CYP3A activity and a unique distribution of CYP3A5 variant alleles in Ethiopians. Pharmacogenomics J. 11, 130-137.

Gervasini, G., Vizcaino, S., Gasiba, C., Carrillo, J.A., Benitez, J., 2005. Differences in CYP3A5*3 genotype distribution and combinations with other polymorphisms between Spaniards and Other Caucasian populations. Ther Drug Monit 27, 819-821.

Haufroid, V., Mourad, M., Van Kerckhove, V., Wawrzyniak, J., De Meyer, M., Eddour, D.C., Malaise, J., Lison, D., Squifflet, J.-P., Wallemacq, P., 2004. The effect of CYP3A5 and MDR1 (ABCB1) polymorphisms on cyclosporine and tacrolimus dose requirements and trough blood levels in stable renal transplant patients. Pharmacogenetics 14, 147-154.

He, P., Court, M.H., Greenblatt, D.J., von Moltke, L.L., 2006. Factors influencing midazolam hydroxylation activity in human liver microsomes. Drug Metab. Dispos. 34, 1198-1207.

Hilli, J., Rane, A., Lundgren, S., Bertilsson, L., Laine, K., 2007. Genetic polymorphism of cytochrome P450s and P-glycoprotein in the Finnish population. Fundam Clin Pharmacol 21, 379-386.

Huang, W., Lin, Y.S., McConn, D.J., 2nd, Calamia, J.C., Totah, R.A., Isoherranen, N., Glodowski, M., Thummel, K.E., 2004. Evidence of significant contribution from CYP3A5 to hepatic drug metabolism. Drug Metab. Dispos. 32, 1434-1445.

King, B.P., Leathart, J.B.S., Mutch, E., Williams, F.M., Daly, A.K., 2003. CYP3A5 phenotype-genotype correlations in a British population. Br J Clin Pharmacol 55, 625-629.

Kuehl, P., Zhang, J., Lin, Y., Lamba, J., Assem, M., Schuetz, J., Watkins, P.B., Daly, A., Wrighton, S.A., Hall, S.D., Maurel, P., Relling, M., Brimer, C., Yasuda, K., Venkataramanan, R., Strom, S., Thummel, K., Boguski, M.S., Schuetz, E., 2001. Sequence diversity in CYP3A promoters and characterization of the genetic basis of polymorphic CYP3A5 expression. Nat. Genet. 27, 383-391.

Lakhman, S.S., Ma, Q., Morse, G.D., 2009. Pharmacogenomics of CYP3A: considerations for HIV treatment. Pharmacogenomics 10, 1323-1339.

Lee, S.-J., Usmani, K.A., Chanas, B., Ghanayem, B., Xi, T., Hodgson, E., Mohrenweiser, H.W., Goldstein, J.A., 2003. Genetic findings and functional studies of human CYP3A5 single nucleotide polymorphisms in different ethnic groups. Pharmacogenetics 13, 461-472.

Makeeva, O., Stepanov, V., Puzyrev, V., Goldstein, D.B., Grossman, I., 2008. Global pharmacogenetics: genetic substructure of Eurasian populations and its effect on variants of drug-metabolizing enzymes. Pharmacogenomics 9, 847-868.

Mirghani, R.A., Sayi, J., Aklillu, E., Allqvist, A., Jande, M., Wennerholm, A., Eriksen, J., Herben, V.M.M., Jones, B.C., Gustafsson, L.L., Bertilsson, L., 2006. CYP3A5 genotype has significant effect on quinine 3-hydroxylation in Tanzanians, who have lower total CYP3A activity than a Swedish population. Pharmacogenet. Genomics 16, 637-645.

Paine, M.F., Hart, H.L., Ludington, S.S., Haining, R.L., Rettie, A.E., Zeldin, D.C., 2006. The human intestinal cytochrome
P450 “pie”. Drug Metab. Dispos. 34, 880-886.

Park, S.Y., Kang, Y.S., Jeong, M.S., Yoon, H.K., Han, K.O., 2008. Frequencies of CYP3A5 genotypes and haplotypes in a Korean population. J Clin Pharm Ther 33, 61-65.

Press, R.R., Ploeger, B.A., den Hartigh, J., van der Straaten, T., van Pelt, J., Danhof, M., de Fijter, J.W., Guchelaar, H.-J., 2009. Explaining variability in tacrolimus pharmacokinetics to optimize early exposure in adult kidney transplant recipients. Ther Drug Monit 31, 187-197.

Quaranta, S., Chevalier, D., Bourgarel-Rey, V., Allorge, D., Solas, C., Lo-Guidice, J.-M., Sampol-Manos, E., Vacher-Coponat, H., Moal, V., Broly, F., Lhermitte, M., Lacarelle, B., 2006a. Identification by single-strand conformational polymorphism analysis of known and new mutations of the CYP3A5 gene in a French population. Toxicol. Lett. 164, 177-184.

Quaranta, S., Chevalier, D., Allorge, D., Lo-Guidice, J.M., MigotNabias, F., Kenani, A., Imbenotte, M., Broly, F., Lacarelle, B., Lhermitte, M., 2006b. Ethnic differences in the distribution of CYP3A5 gene polymorphisms. Xenobiotica 36, 1191-1200.

Roco, A., Quiñones, L., Agúndez, J.A.G., García-Martín, E., Squicciarini, V., Miranda, C., Garay, J., Farfán, N., Saavedra, I., Cáceres, D., Ibarra, C., Varela, N., 2012. Frequencies of 23 functionally significant variant alleles related with metabolism of antineoplastic drugs in the chilean population: comparison with caucasian and asian populations. Front Genet 3, 229.

Roy, J.-N., Lajoie, J., Zijenah, L.S., Barama, A., Poirier, C., Ward, B.J., Roger, M., 2005. CYP3A5 genetic polymorphisms in different ethnic populations. Drug Metab. Dispos. 33, 884-887.

Semiz, S., Dujić, T., Ostanek, B., Prnjavorac, B., Bego, T., Malenica, M., Mlinar, B., Marc, J., Causević, A., 2011. Analysis of CYP3A4*1B and CYP3A $5 * 3$ polymorphisms in population of Bosnia and Herzegovina. Med Glas (Zenica) 8, 84-89.

Seredina, T.A., Goreva, O.B., Talaban, V.O., Grishanova, A.Y., Lyakhovich, V.V., 2012. Association of cytochrome P450 genetic polymorphisms with neoadjuvant chemotherapy efficacy in breast cancer patients. BMC Med. Genet. 13, 45.

Sinues, B., Vicente, J., Fanlo, A., Vasquez, P., Medina, J.C., Mayayo, E., Conde, B., Arenaz, I., Martinez-Jarreta, B., 2007. CYP3A5*3 and CYP3A4*1B allele distribution and genotype combinations: differences between Spaniards and Central Americans. Ther Drug Monit 29, 412-416.

Solas, C., Simon, N., Drogoul, M.-P., Quaranta, S., FrixonMarin, V., Bourgarel-Rey, V., Brunet, C., Gastaut, J.-A., Durand, A., Lacarelle, B., Poizot-Martin, I., 2007. Minimal effect of MDR1 and CYP3A5 genetic polymorphisms on the pharmacokinetics of indinavir in HIV-infected patients. Br J Clin Pharmacol 64, 353-362.

Suarez-Kurtz, G., Perini, J.A., Bastos-Rodrigues, L., Pena, S.D.J., Struchiner, C., 2007. Impact of population admixture on the distribution of the CYP3A $5 * 3$ polymorphism. Pharmacogenomics 8, 1299-1306.

Thompson, E.E., Kuttab-Boulos, H., Witonsky, D., Yang, L., Roe, B.A., Di Rienzo, A., 2004. CYP3A variation and the evolution of salt-sensitivity variants. Am. J. Hum. Genet. 75, 1059-1069.

Turolo, S., Tirelli, A.S., Ferraresso, M., Ghio, L., Belingheri, M., Groppali, E., Torresani, E., Edefonti, A., 2010. Frequencies and roles of CYP3A5, CYP3A4 and ABCB1 single nucleotide polymorphisms in Italian teenagers after kidney transplantation. Pharmacol Rep 62, 1159-1169.

Vaarala, M.H., Mattila, H., Ohtonen, P., Tammela, T.L.J., Paavonen, T.K., Schleutker, J., 2008. The interaction of 
CYP3A5 polymorphisms along the androgen metabolism pathway in prostate cancer. Int. J. Cancer 122, 2511-2516.

Van Schaik, R.H.N., van der Heiden, I.P., van den Anker, J.N., Lindemans, J., 2002. CYP3A5 variant allele frequencies in Dutch Caucasians. Clin. Chem. 48, 1668-1671.

Wang ,D., Sadee,W., 2012. The Making of a CYP3A Biomarker
Panel for Guiding Drug Therapy. J. Pers. Med. 2, 175-191. Zeigler-Johnson, C., Friebel, T., Walker, A.H., Wang, Y., Spangler, E., Panossian, S., Patacsil, M., Aplenc, R., Wein, A.J., Malkowicz, S.B., Rebbeck, T.R., 2004. CYP3A4, CYP3A5, and CYP3A43 genotypes and haplotypes in the etiology and severity of prostate cancer. Cancer Res. $64,8461-8467$.

\title{
Резиме
}

\section{Фрекфенција на најчестите CYP3А5 полиморфизми во здрава популација во Република Македонија}

\author{
Круме Јаковски ${ }^{1}$,Александра Капедановска Несторовска², Никола Лабачевски ${ }^{1}$, \\ Александар J. Димовски ${ }^{2}$
}

\author{
${ }^{1}$ Институт за Предклиничка и Клиничка Фрамакологија и Токсикологија, Медицински Факултет, \\ Универзитет „,Св.Кирил и Методиј“ - Скопје, Р.Македонија. \\ ${ }^{2}$ Центар за Биомолекуларни Фармацевтски Анализи, Фармацевтски факултет, \\ Универзитет „Св.Кирил и Методиј“ - Скопје, Р.Македонија.
}

Клучни зборови: еднонуклеотидни полиморфизми, СYР3А5, популациона фрекфенција, Република Македонија

Утврдено е дека генетските полиморфизми кои влијаат на активноста на СҮР3А5 ензимот претставуваат еден од факторите кои придонесуваат за интериндивидуална и интеретничка варијабилност во метаболизмот на СҮР3А5 субстратите. Целта на ова истражување беше да се одреди дистрибуцијата на најчестите CYP3A $5 * 3$ полиморфни варијанти во здрава популација од Република Македонија и да се утврди дали фреквенцијата на варијантните алели е во рамките на публикуваните податоци за Европската популација. Во студијата беа вклучени вкупно 174 здрави доброволци од генералната популација од Р. Македонија. Генотипизацијата на СРР3А5*3 варијантните алели, *3А (rs15524) и *3E (rs28365095), беше направена со примена на методот на Real-Time Полимераза Верижна Реакција (Polymerase Chain Reaction- PCR) [MxPro 3005P, Stratagene, La Jolla, CA, USA] и употреба на специфични TaqMan SNP тестови за генотипизација, во услови согласно препораките на производителот [Applied Biosystems, Foster City, CA, USA]. Добиените резултати покажуваат дека CYP3A5*3 алел е доминантно присутен во фрекфенција од 0.922. Приближно $82 \%$ од Македонската популација се хомозиготи за варијантниот алел и воопшто не поседуваат СҮР 3 А5 ензимска активност. Дистрибуцијата на испитуваните СҮР 35 полиморфизми во Р. Македонија е слична со дистрибуцијата на другите Европски популации. Овие резултати претставуваат основа за понатамошни фармакогенетски истражувања во нашата држава. 


\title{
The influence of duration of the distillation of fresh and dried flowers on the essential oil composition of lavandin cultivated in Republic of Macedonia
}

\author{
Marija Karapandzova*, Ivana Cvetkovikj, Gjoshe Stefkov, Vlatko Stoimenov, \\ Martin Crvenov, Svetlana Kulevanova
}

Institute of Pharmacognosy, Faculty of Pharmacy, University “Ss Cyril and Methodius”, Skopje, Republic of Macedonia

Received: October 2012, Accepted: November 2012

\begin{abstract}
The main objective of this study was to analyze the essential oil composition of cultivated lavandin (Lavandula $x$ intermedia Emeric ex Loisel., Lamiaceae) from Republic of Macedonia and to evaluate the influence of the drying time of plant material and the distillation duration on the oil composition. Four different essential oils were obtained by hydrodistillation in a Clevenger type apparatus from freshly harvested and air dried flowers of lavandin and varying in distillation time (30 min and $2 \mathrm{~h}$ ). Fifty-six compounds were identified by GC/ FID/MS representing $96.57 \%$ to $98.23 \%$ of the total oil. Prevailing constituents in all tested oils were linalool, borneol and terpinene-4-ol, present in amounts from 35.23 to $42.24 \%, 12.28$ to $16.68 \%$ and 4.44 to $5.62 \%$, respectively. The content of 1,8-cineole varied from $3.99 \%$ to $8.42 \%$ while that of camphor was between $5.96 \%$ and $7.04 \%$. Linalyl acetate was present in amounts from $1.26 \%$ to $3.21 \%$. Unexpectedly, the duration of distillation insignificantly influenced the essential oil composition. Few differences, mainly in the content of borneol $(13.71 \%$ and $16.68 \%$ in the oil from fresh and dried flowers, respectively) were recorded in the essential oils obtained by 30 minutes distillation, while the content of the other constituents was almost unchanged. However, the isolated essential oils of lavandin did not comply with the international standards requirements for the lavandin essential oil composition.
\end{abstract}

Key wards: Lavandula intermedia, Lamiaceae, GC/FID/MS, duration of hydrodistillation, drying time

\section{Introduction}

Medicinally and commercially important Lavandula species are perennial shrubs growing in rocky and calcareous areas in Mediterranean basin. For commercial production of essential oil, three species are used: L. angustifolia Mill. (common or English lavender), L. latifolia Medik. (spike lavender) and L. angustifolia $x$ L. latifolia (L. $x$ intermedia Emeric ex Loisel.) known as lavandin. There are also several cultivars that are planted for commercial production of essential oils with similar features to lavandin, such as: Grappenhall, Provence, Grosso, Dutch

\footnotetext{
* marija karapandzova@ff.ukim.edu.mk
}

Mill, Abrial and Seal (lavender production, http://www. nda.agric.za/docs/brochures/essoilslavender.pdf).

Lavender flowers and oil are often used in the households as an herbal remedy for nervous disturbance and flatulence while externally are used to cure nervous headache (Gamez et al., 1990), anxiety and mild depression (Lewis \& Kowalski, 2002; Lenrner et al., 2005). The essential oil act with powerful antimicrobial properties (Sabara and $\mathrm{Ku}$ nicka-Styczynska, 2009) and is useful in the treatment of burns, sunburns, scalds, bites, vaginal discharge and anal fissure (Shafaghat et al., 2012). It is also known as antioxidant (Economou et al., 1991), antispasmodic (Cavanagh and Wilkinson, 2002), aromatic, carminative, cholagoge, diuretic, nervine, sedative, stimulative, stomachic and tonic (Lis-Balchin and Hart, 1999; Gilani et al., 2000; 
Kalemba and Kunicka, 2003). It is used in aromatherapy as well (Sabara and Kunicka-Styczynska, 2009). Industrial application of lavender oil include production of high-quality perfumes, candles, incense sachets, potpourri, wands, pillows, flower bundles, dried arrangements, wall hangings, wreaths and (Pauls et al., 2004) is used in bath products such as soap, shampoo, bath oil, lotion and bath salt. Owing to its safety and sedative action it is incorporated extensively in cosmetic preparations (Azar et al., 2011). In food manufacturing it is added in flavoring beverages, ice-creams, candy, baked goods and chewing gum (Kim and Lee, 2002, Wogiatzi et al., 2011).

The world's production of Lavandula species is mainly directed to lavandin cultivars, which have more vigorous growth and give greater amounts of essential oil. The average annual production of lavandin essential oil riches 1200 tons traditionally produced in Europe and United States (Peterson, 2002). On the other hand, the world production of lavender (L. angustifolia) oil is only 200 tons per annum, predominantly emanating out of Europe (Peterson, 2002). It is well known that chemical composition of the essential oils of lavender and lavandin largely depend on the species from which it is obtained (Kustrak and Besic, 1975; Wogiatzi et al., 2011). Key differences in the composition of these oils is the low amount of camphor (less than 1\%) and the absence of bornyl acetate in lavender (L. angustifolia) oil, while lavandin (L. intermedia) oil contains camphor between $10-12 \%$ and linalool up to $20 \%$ (Peterson, 2002).

The characteristic odor of lavender oil originates from the presence of linalyl acetate and according to the regulations lavender oil should not contain less than $25 \%$ of this constituent. Additionally, the content of 1,8-cineole should be less than $2.5 \%$ (Ph. Eur. 7). On the other hand, the content of these components in lavandin essential oil varies a lot depending on the characteristics of the cultivars and other factors (Wogiatzi et al., 2011).

Lavender oil can be easily isolated from the flower heads using steam distillation. The time of distillation influences the essential oil composition and its quality. If distillation time is too short, compounds with higher boiling point may be missing from the oil. When the time of distillation is too long, the oil may have unpleasant smell. According some authors, nearly $75 \%$ of the total yield comes in the first 25 minutes of distillation and gives a commercial grade of lavender oil (Pitman, 2004). Even the steam distillation is still the most preferable technique of oil isolation, during this process, molecular rearrangements, hydratation of double bonds and hydrolyzis of esters to alcohols and carboxylic acids can occur. In high-quality lavender oil the ratio between linalyl acetate and linalool should be higher than one (Porter et al., 1982; Wesolowska et al., 2010). Linalool poses sweet odor and linalyl acetate refreshing one, appreciated in many applications (Wesolowska et al., 2010). Nowadays, commercially produced lavender oil is often distilled for only 15 minutes at a very high temperature and under very high pressure (Wesolowska et al., 2010). Because of its poor quality, synthetic linalyl acetate is often added in order to make it smell like the genuine plant fragrance (Sell, 2006; Wesolowska et al., 2010).

Within the one Lavandula species, the essential oil composition differs significantly depending on where and under what condition the plant was grown (Guillen et al., 1996). Other variations in essential oil composition may occur depending on duration, temperature and pressure of distillation (Wesolowska et al., 2010). Therefore, the aim of the present study was to evaluate the influence of distillation time on the composition of lavandin (L. $x$ intermedia) essential oil as well as to determine the differences in chemical composition of the oils isolated from fresh or dried flowers of lavandin cultivated in Republic of Macedonia. Obtained results will be evaluated according to different standards requirements.

\section{Material and methods}

\section{Plant material}

Flowering tops of cultivated lavandin were collected in a full blooming of plants during the summer 2012. A voucher specimen of the plant was deposited at the Herbarium of the Institute of Pharmacognosy and Pharmaceutical Botany at the Faculty of Pharmacy in Skopje, Republic of Macedonia (No. LI-01/012). Proper amount of freshly collected material was distilled during the same day and the rest was put on a paper sheets in a shade and left to air drying. Dried flowers were also used for isolation of essential oil.

\section{Essential oil isolation}

Essential oils were isolated by hydrodistillation in a Clevenger-type apparatus following the procedure from European Pharmacopeia (Ph. Eur. 7). Four different essential oils were isolated from fresh and dried flowers of lavandin, by distillation lasting $30 \mathrm{~min}$ and $2 \mathrm{hrs}$. The obtained oils were dried over anhydrous sodium sulfate and stored in refrigerator until analysis. Two repetition of distillation were performed.

\section{GC/FID/MS analysis}

Essential oil samples were analyzed on Agilent 7890A Gas Chromatography system equipped with flame ionization detector (FID) and Agilent 5975C mass spectrometer (MS) equipped with capillary flow technology which enables simultaneous analysis of the sample on both detectors. HP-5MS (30 m x $0.25 \mathrm{~mm}$, film thickness $0.25 \mu \mathrm{m}$ ) capillary column was used. Operating conditions were as follows: oven temperature $60{ }^{\circ} \mathrm{C}(5 \mathrm{~min}), 1{ }^{\circ} \mathrm{C} / \mathrm{min}$ to 80 ${ }^{\circ} \mathrm{C}(2 \mathrm{~min})$ and $5{ }^{\circ} \mathrm{C} / \mathrm{min}$ to $280{ }^{\circ} \mathrm{C}(5 \mathrm{~min})$; flow rate of $1 \mathrm{ml} / \mathrm{min}(\mathrm{He})$; injector $\mathrm{T}=260{ }^{\circ} \mathrm{C}$; FID $\mathrm{T}=270{ }^{\circ} \mathrm{C}$; $1 \mu \mathrm{l}$ injection volume at split ratio $1: 1$. 
The mass spectrometry conditions were: ionization energy $70 \mathrm{eV}$, ion source temperature $230{ }^{\circ} \mathrm{C}$, transfer line temperature $280{ }^{\circ} \mathrm{C}$ and mass range from $50-500$ Da. The MS was operated in scan mode. Identification of the components present in essential oils was made by comparing mass spectra of components in essential oils with those from NIST, Wiley and Adams mass spectra libraries, by AMDIS (Automated Mass Spectral Deconvolution and Identification System) and by comparing literature and estimated Kovat's (retention) indices that were determined using mixture of homologous series of normal alkanes from $\mathrm{C}_{9}$ to $\mathrm{C}_{25}$ in hexane, under the same above mentioned conditions.

The percentage ratio of essential oils components was computed by the normalization method of the GC/FID peak areas and average values were taken into further consideration $(n=3)$.

\section{Results and discussion}

The results of GC/FID/MS analysis of the essential oils, isolated from fresh and dried flowers of lavandin, obtained either by hydrodistillation of 30 minutes or 2 hours duration, are presented in Table 1. Total of fifty-six compounds were identified in the analyzed samples of lavandin representing $96.57 \%$ to $98.23 \%$ of the total oil. The most abundant compound in the analyzed essential oils was lina- lool ( 35.23 to $42.24 \%$ ), followed by borneol and terpinene4-ol, presented in amounts from $12.28 \%$ to $16.68 \%$ and from $4.44 \%$ to $5.62 \%$, respectively. The content of 1,8 -cineole varied from $3.99 \%$ to $8.42 \%$ and that of camphor between $5.96 \%$ and $7.04 \%$. In all tested samples of lavandin oil the content of linalyl acetate was very low, presented in amounts from $1.26 \%$ to $3.21 \%$. Similar quantities of lavandulyl acetate were determined (1.53-2.42\%).

From the presented results a smaller decrease in the content of linalool can be noticed when prolonged distillation procedure was applied $(38.58 \%)$ compared to the 30 minutes distillation procedure $(40.13 \%)$. Similar trend of decreasing was noticed in the abundance of almost all other dominant compounds. For instance camphor amount decreased from $6.62 \%$ to $5.96 \%$, borneol from $13.71 \%$ to $12.28 \%$ and terpinene-4-ol from $5.62 \%$ to $5.24 \%$. The 2 hrs hydrodistillation increased the amount of 1,8-cineole (from $7.17 \%$ to $7.39 \%$ ), cis- $\beta$-ocimene (from $2.45 \%$ to $2.54 \%$ ) and trans- $\beta$-ocimene (from $0.78 \%$ to $0.85 \%$ ) (Table 1). Increased content after prolonged distillation of fresh flowers was also notice in eugenol (from $0.00 \%$ to $1.89 \%$ ) and eugenol acetate (from $0.04 \%$ to $3.05 \%$ ). Also, few other esterified monoterpene compounds were identified in very small quantities, linalyl and lavandulyl acetate, followed by bornyl, neryl and geranyl acetate and lavandulyl isovalerate. After all, essential oils obtained from fresh flowers by 30 minutes and 2 hours lasting distillation pro-

Table 1. Chemical composition of the essential oils isolated from lavandin (\%)

\begin{tabular}{|c|c|c|c|c|c|c|c|}
\hline \multirow[b]{2}{*}{ No. } & \multirow[b]{2}{*}{ KIL } & \multirow[b]{2}{*}{ KIE } & \multirow[b]{2}{*}{ Components } & \multicolumn{2}{|c|}{ Fresh flowers } & \multicolumn{2}{|c|}{ Dried flowers } \\
\hline & & & & $2 \mathrm{~h}$ & $30 \mathrm{~min}$. & $2 \mathrm{~h}$ & $30 \mathrm{~min}$. \\
\hline 1 & 931 & 940.3 & $\alpha$-Thujene & - & $\operatorname{tr}$ & - & - \\
\hline 2 & 939 & 944.2 & $\alpha$-Pinene & 0.21 & 0.18 & 0.30 & - \\
\hline 3 & 953 & 953.7 & Camphene & 0.50 & 0.50 & 0.56 & - \\
\hline 4 & 975 & 970.7 & Sabinene & 0.11 & 0.12 & 0.15 & - \\
\hline 5 & 980 & 972.8 & $\beta$-Pinene & 0.24 & 0.20 & 0.26 & 0.46 \\
\hline 6 & 991 & 984.4 & Myrcene & 1.01 & 0.93 & 1.09 & $\operatorname{tr}$ \\
\hline 7 & 1007 & 999.1 & $\Delta^{3}$-Carene & 0.27 & 0.23 & 0.34 & - \\
\hline 8 & 1018 & 1004.8 & $\alpha$-Terpinene & $\operatorname{tr}$ & - & - & - \\
\hline 9 & 1025 & 1011.9 & $p$-Cymene & 0.13 & 0.06 & 0.12 & - \\
\hline 10 & 1031 & 1015.5 & $\beta$-Phellandrene & 3.84 & 3.64 & 4.41 & 1.16 \\
\hline 11 & 1033 & 1017.2 & 1,8-Cineole & 7.39 & 7.17 & 8.42 & 3.99 \\
\hline 12 & 1040 & 1025.4 & cis- $\beta$-Ocimene & 2.54 & 2.45 & 3.15 & 1.17 \\
\hline 13 & 1050 & 1035.1 & trans- $\beta$-Ocimene & 0.85 & 0.78 & 1.11 & 0.42 \\
\hline 14 & 1062 & 1044.1 & $\gamma$-Terpinene & 0.20 & 0.15 & 0.25 & 0.13 \\
\hline 15 & 1088 & 1073.5 & $\alpha$-Terpinolene & 0.45 & 0.43 & 0.52 & 0.26 \\
\hline 16 & 1098 & 1091.8 & Linalool & 38.58 & 40.13 & 35.23 & 42.24 \\
\hline 17 & 1142 & 1125.7 & neo-allo-Ocimene & 0.87 & 0.64 & 0.87 & - \\
\hline
\end{tabular}




\begin{tabular}{|c|c|c|c|c|c|c|c|}
\hline & & & & & vers & Drie & vers \\
\hline No. & KIL & KIE & Components & $2 \mathrm{~h}$ & $30 \mathrm{~min}$. & $2 \mathrm{~h}$ & $30 \mathrm{~min}$. \\
\hline 18 & 1143 & 1139.2 & Camphor & 5.96 & 6.62 & 6.84 & 7.04 \\
\hline 19 & 1150 & 1150.0 & Hexyl isobutyrate & $\operatorname{tr}$ & 0.07 & - & - \\
\hline 20 & 1162 & 1159.3 & Pinocarvone & - & - & 0.09 & 0.11 \\
\hline 21 & 1165 & 1162.9 & Borneol & 12.28 & 13.71 & 13.77 & 16.68 \\
\hline 22 & 1166 & 1166.2 & Lavandulol & 1.65 & 1.70 & 1.52 & 1.93 \\
\hline 23 & 1177 & 1172.5 & Terpinene-4-ol & 5.24 & 5.62 & 4.44 & 5.25 \\
\hline 24 & 1183 & 1180.0 & $p$-Cymene-8-ol & $\operatorname{tr}$ & - & $\operatorname{tr}$ & $\operatorname{tr}$ \\
\hline 25 & 1189 & 1183.3 & $\alpha$-Terpineol & 1.24 & 1.25 & 1.35 & 1.35 \\
\hline 26 & 1191 & 1186.8 & Hexyl butyrate & 0.48 & 0.55 & 0.46 & 0.59 \\
\hline 27 & 1193 & 1195.9 & $c i s$-Piperitol & $\operatorname{tr}$ & 0.05 & 0.08 & 0.10 \\
\hline 28 & 1212 & 1205.7 & trans-Carveol & $\operatorname{tr}$ & $\operatorname{tr}$ & 0.11 & 0.06 \\
\hline 29 & 1228 & 1217.7 & Nerol & 0.15 & 0.12 & 0.16 & 0.14 \\
\hline 30 & 1239 & 1227.2 & Cumic aldehyde & 0.29 & 0.33 & 0.42 & 0.46 \\
\hline 31 & 1243 & 1232.7 & Carvone & 0.14 & 0.20 & 0.25 & 0.29 \\
\hline 32 & 1256 & 1245.7 & Linalyl acetate & 1.26 & 2.18 & 1.86 & 3.21 \\
\hline 33 & 1285 & 1272.7 & Bornyl acetate & 0.07 & 0.07 & 0.09 & 0.11 \\
\hline 34 & 1289 & 1278.5 & Lavandulyl acetate & 1.53 & 1.64 & 1.84 & 2.42 \\
\hline 35 & 1290 & 1290.9 & Thymol & $\operatorname{tr}$ & - & - & - \\
\hline 36 & 1331 & 1314.6 & Hexyl tiglate & 0.03 & 0.05 & 0.06 & 0.06 \\
\hline 37 & 1356 & 1341.6 & Eugenol & 1.89 & - & - & - \\
\hline 38 & 1365 & 1348.0 & Neryl acetate & 0.38 & 0.18 & 0.26 & 0.24 \\
\hline 39 & 1380 & 1362.9 & Daucene & 0.05 & 0.06 & 0.07 & 0.08 \\
\hline 40 & 1383 & 1366.3 & Geranyl acetate & 0.40 & 0.32 & 0.40 & 0.39 \\
\hline 41 & 1409 & 1390.4 & $\alpha$-Gurjunene & $\operatorname{tr}$ & 0.03 & 0.03 & 0.05 \\
\hline 42 & 1418 & 1399.6 & trans-Caryophyllene & 0.39 & 0.48 & 0.63 & 0.67 \\
\hline 43 & 1458 & 1435.4 & trans- $\beta$-Farnesene & 1.18 & 1.60 & 2.08 & 2.21 \\
\hline 44 & 1477 & 1450.4 & $\gamma$-Muurolene & 0.04 & 0.06 & 0.08 & 0.08 \\
\hline 45 & 1480 & 1462.5 & Germacrene D & 0.08 & 0.09 & 0.12 & 0.12 \\
\hline 46 & 1510 & 1486.0 & Lavandulyl isovalerate & 0.49 & 0.61 & 0.75 & 0.80 \\
\hline 47 & 1513 & 1493.6 & $\gamma$-Cadinene & 0.04 & 0.06 & 0.10 & 0.09 \\
\hline 48 & 1524 & 1501.7 & $\delta$-Cadinene & $\operatorname{tr}$ & $\operatorname{tr}$ & 0.08 & 0.06 \\
\hline 49 & 1536 & 1505.0 & Eugenol acetate & 3.05 & 0.04 & - & - \\
\hline 50 & 1564 & 1539.7 & trans-Nerolidol & $\operatorname{tr}$ & - & $\operatorname{tr}$ & - \\
\hline 51 & 1574 & 1557.1 & Germacrene-D-4-ol & 0.05 & - & - & $\operatorname{tr}$ \\
\hline 52 & 1581 & 1565.5 & Caryophyllene oxide & 0.15 & 0.18 & 0.22 & 0.27 \\
\hline 53 & 1627 & 1595.5 & 1-epi-Cubenol & $\operatorname{tr}$ & $\operatorname{tr}$ & $\operatorname{tr}$ & $\operatorname{tr}$ \\
\hline 54 & 1641 & 1621.0 & $\tau$-Cadinol (epi- $\alpha-$-Cadinol) & 0.28 & 0.21 & 0.20 & 0.19 \\
\hline 55 & 1653 & 1634.9 & $\alpha$-Cadinol & 0.13 & 0.07 & 0.08 & 0.07 \\
\hline \multirow[t]{2}{*}{56} & 1686 & 1661.8 & $\alpha$-epi-Bisabolol & 1.92 & 2.00 & 1.60 & 1.54 \\
\hline & & & Total: & 98.23 & 97.84 & 96.88 & 96.57 \\
\hline
\end{tabular}

$\mathrm{n}=3 ; \operatorname{tr}<0,02 \%$; (-) - not present; KIL - Kovats (retention) index - literature data; KIE - Kovats (retention) index experimentally determined (AMDIS) 


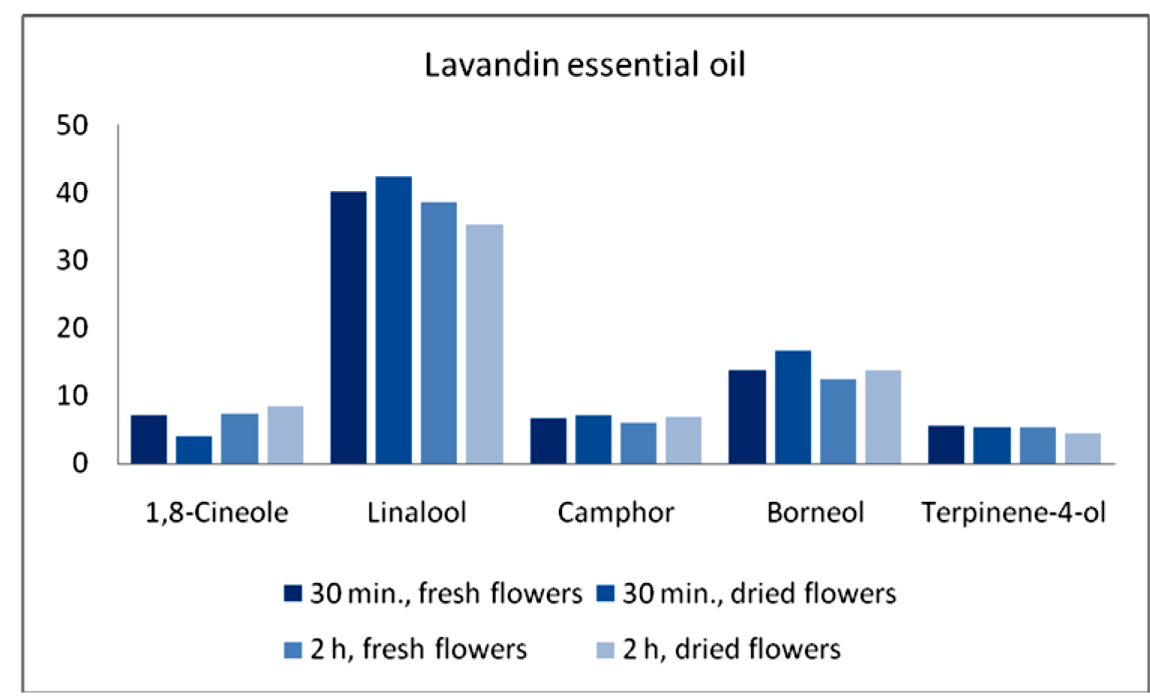

Fig. 1. The content of the main compounds in lavandin essential oil after 30 minutes and 2 hours distillation of fresh or dried lavandin flowers.

cedures showed insignificant variance in essential oil composition and the main constituents (linalool, borneol, 1,8cineole, camphor and terpinene-4-ol) content (Fig. 1).

At the same time, there were significant differences in the essential oil composition of tested lavandin compared to various essential oils originated from diverse regions world-wide (Table 2). Higher amounts of borneol were found in our lavandin oils than spike lavender oil that shows high level of linalool, 1,8-cineole and camphor and very low level of linalyl acetate (Table 1 and 2). Analyzed lavandin essential oils were more similar to the spike lavender oil than to oils of lavandin cultivars (var. "grosso" and var. "abrial"). This findings correlate with the
Renaud's report for the essential oil composition of 10 cultivars of lavandin and lavender, including $L$. x intermedia varieties stating that lavandin "grosso" oil has the highest amount of camphor (8.1\%) and low amount of borneol (Renaud et al., 2001).

It is worth to be mentioned that L. $x$ intermedia ( $L$. angustifolia $x$ L. latifolia) is a hybrid different from L. $x$ hybrida Balb. ex Ging. (L. dendata $x$ L. latifolia) that produces essential oil with different chemical composition with 1,8-cineole (up to $33.5 \%$ ) and camphor (up to $12.4 \%$ ) as major constituents (Tucker et al., 1993). On the other hand, Chu and Kemper used L. $x$ intermedia as a synonym for $L$. $x$ hybrida Reverchon or L. $x$ hybrida Burnamii (lavandin,

Table 2. The chemical composition of various lavender and lavandin oils (\%) (according to International standards)*

\begin{tabular}{lcccc}
\hline \hline Constituent & $\begin{array}{c}\text { L. angustifolia } \\
\text { Lavender }\end{array}$ & $\begin{array}{c}\text { L. intermedia } \\
\text { Lavandin "Grosso" }\end{array}$ & $\begin{array}{c}\text { L. intermedia } \\
\text { Lavandin "Abrial” }\end{array}$ & $\begin{array}{c}\text { L. latifolia } \\
\text { Spike lavender }\end{array}$ \\
\hline Linalool & $25-38$ & $24-35$ & $26-38$ & $34-50$ \\
Linalyl acetate & $25-45$ & $28-38$ & $20-29$ & $<1.6$ \\
$1,8-$ Cineole & $1-2$ & $4-7$ & $6-11$ & $16-39$ \\
$\beta$-Caryophyllene & $3-12$ & - & - & - \\
Limonene & $<1.0$ & $0.5-1.5$ & $0.5-1.5$ & $0.5-3$ \\
Terpinene-4-ol & $2-6$ & $1.5-5$ & $0.3-1$ & - \\
$\beta$-Ocimene & $2.5-6$ & $0.5-1.5$ & $1.5-7$ & - \\
Lavandulyl acetate & $3.4-6.2$ & $1.5-3$ & $1-2$ & - \\
Lavandulol & $>0.1$ & $0.2-0.8$ & $0.4-1.2$ & - \\
$\alpha-$ Terpineol & $<2$ & - & - & $0.2-2$ \\
Camphor & $0.5-1$ & $6-8$ & $7-11$ & $10-20$ \\
trans- $\alpha-B i s a b o l e n$ & - & - & - & $0.4-2.5$ \\
Borneol & - & $1.5-3$ & $1.5-3.5$ & - \\
Pinene & - & - & - & $1-3$ \\
\hline
\end{tabular}

*data published by MacTavish and Harris, 2002 
a hybrid of L. angustifolia $x$ L. latifolia), different species from L. $x$ hybrida Balb. ex Ging. (L. dendata $x$ L. latifolia) (Chu and Kemper, 2001). Anyhow, the chemical composition of analyzed lavandin oils could not met the international standard requirements for this oil.

Wesołowska stated that the time of distillation had a significant influence on the content of lavender oil constituents (Wesołowska et al., 2010). Zhekova and Nedkov pointed out that there are divided opinions about variability of the content of the main compounds in lavender oil during the distillation process. For instance, linalyl acetate, compound used for quality assessment compound of lavender oil, could be found in large quantities in the first 15 minutes of the distillation process. The same authors reported that highest oil yield from true lavender was gained within the first 15 minutes of the distillation. The quantity of linalyl acetate was constantly increased during entire 30 minutes and the oils separate between 15 and 30 minute possessed the best smell performance. For the other varieties it was indicated that during the process of distillation the amount of linalyl acetate, linalool and $\beta$-ocimene had declined. It was also noticed that the undesirable components for the smell of lavender oil, such as borneol and terpinene-4-ol, had greater content than before (Zhekova and Nedkov, 2010). Our results showed that borneol was present in high amount in the analyzed lavandin oils in all experimental cases (12.28-16.68\%) and opposite to above findings decreased with prolonged distillation of $2 \mathrm{~h}$. The amount of the undesirable monoterpene alcohol, terpinene4-ol was almost constant in all experimental conditions (4.44-5.62\%).

Commercially available lavender and lavandin essential oils are produced by distillation of freshly harvested plant material (flowering tops in full blossom). Distillation process is usually carefully designed as it can increase or reduce the value of the oil (lavender production, www. nda.agric.za/docs/brochures/essoilslavender.pdf). The duration, pressure, temperature and the average speed of distillation are factors that influence the essential oil quality. On the other hand, for research and experimental purposes, the essential oils are isolated in Clevenger type apparatus often from dried plant material and then analyzed by GC-MS (Ihsan, 2008; Wesolowska et al., 2010; Azar et al., 2011; Najafian et al., 2012; Shafaghat et al., 2012). Some authors compared the essential oil composition of oils obtained from fresh and dried lavender and found significant similarities in the oils' composition. Thus, the percentages of 1,8-cineole, linalool, borneol, camphor and linalyl acetate in essential oil from fresh lavender were $18.9 \%, 34.2 \%$, $12.1 \%, 4.6 \%$ and $3.1 \%$, respectively and were almost identical in the oil obtained from dried lavender $(20.3 \%, 33.0 \%$, $11.0 \%, 4.7 \%$ and $3.6 \%$ for 1,8 -cineole, linalool, borneol, camphor and linalyl acetate, respectively) (Ihsan, 2008).

The obtained results showed that drying of the lavandin inconsiderably influenced the essential oil composition and the whole character of the lavandin oil remained al- most unaffected (Fig. 1). This finding are in accordance with data published previously for lavender oil (Ihsan, 2008).

\section{Conclusion}

Essential oil composition of cultivated lavandin ( $L . x$ intermedia) from Republic of Macedonia, analyzed by $\mathrm{GC} /$ FID/MS, showed presence of fifty-six compounds representing $96.57 \%$ to $98.23 \%$ of the total oil. The main identified constituents of the oil were linalool (35.23-42.24\%), borneol (12.28-16.68\%), 1,8-cineole (3.99-8.42\%), camphor (5.96-7.04\%) and terpinene-4-ol (4.44-5.62\%), while linalyl acetate was present in very low amounts (1.53$2.42 \%$ ). Regardless the duration of the distillation process ( $30 \mathrm{~min}$ and $2 \mathrm{hrs)}$ and differences in the characteristics of plant material (fresh or dried flowering tops), the isolated lavandin oils did not show significant differences in their chemical composition

The chemical composition of analyzed lavandin oils did not comply with the international standard requirements.

\section{References}

Azar, P.A., Torabbeigi, M., Sharifan, A., Tehrani, M.S., 2011. Chemical composition and antibacterial activity of the essential oil of Lavandula angustofolia isolated by solvent free microwave assisted extraction and hydrodistillation, J. Food Biosci. Technol. 1, 19-24.

Ballabani, V., Tagnolini, M., Chiavarini, M., Impicciatore, M., Bruni, R., Ianchi, A., Barocelli, E., 2004. Novel antiplatelet and antitrombotic activities of essential oil from Lavandula hybrida Reverchon "grosso", Phytomedicine 11, 596-601.

Baydar, H., Kineci, S., 2009. Scent composition of essential oil, concrete, absolute and hydrosol from Lavandin (Lavandula $x$ intermedia Emeric ex Loisel.). J. Essent. Oil - bearing Plants 12 (2), 131-136.

Boeckelmann, A., 2008. Monoterpene production and regulation in lavenders (Lavandula angustifolia and Lavandula $x$ intermedia). Available at: http://hdl.handle.net/2429/2804

Cavanagh, H.M.A., Wilkinson, J.M., 2002. Biological activities of lavender essential oil. Phytother. Res. 16, 301-308.

Chu, C.J., Kemper, K.J., 2001. Lavender (Lavandula spp.), The Longwood Herbal Task Force

(http://www.mcp.edu/herbal/) and The Center for Holistic Pediatric Education and Research

(http://www.childrenshospital.org/holistic/). Available at: http:// www.longwoodherbal.org/lavender/lavender.pdf

Economou, K.D., Oreopoulou, V., Thomopoulus, C.D., 1991. Antioxidant activity of some plant extracts of the family Labiatae. J. Am. Oil Chem. Soc. 68, 109-115.

European Pharmacopeia 7.0, 2010. Council of Europe, Strasbourg, France. 1163-1164.

Gamez, M.J., Jimenez, J., Mavarro, C., Zarzuelo, A., 1990. Study of the essential oil of Lavandula dentate L. Pharmazie 45, 69-76.

Gilani, A.H., Aziz, N., Khan, M.A., Shaheen, F., Jabeen, Q., Siddidui, B.S., Herzig, J.W., 2000. Ethnopharmacological evaluation of the anticonvulsant, sedative and antispasmodic 
activities of Lavandulae stoechas L. J. Ethnopharmacol. 71, 161-167.

Ihsan, S.A., 2008. Essential oil composition of Lavandula officinalis L. grown in Jordan. Journal of Kerbala University 6, 209-212.

Guillen, M.D., Cabo, N., Burillo, J., 1996. Characterization of the essential oils of some cultivated aromatic plants of industrial interest. J. Sci. Food Agric. 70, 359-363.

Kalemba, D., Kunicka, A., 2003. Antibacterial and antifungal properties of essential oils. Curr. Med. Chem. 10, 12411253

Kim, N.S., Lee, D.S., 2002. Comparison of different extraction methods for analysis of fragrances from Lavandula species by gas chromatography-mass spectrometry. J. Chromatogr. 982, 31-47.

Kustrak, D., Besic, J., 1975. Aetheroleum Lavandulae and aetheroleum Lavandulae hybridae in Pharmacopeia Jugoslavia III. Pharmaceutica Acta Helvetiae 50, 373-378.

Lavender production, Essential oil crops. 2012. Available at: http://www.nda.agric.za/docs/brochures/essoilslavender.pdf

Lehrner, J., Marwincski, G., Lehr, S., Deecke L., 2005. Ambient odors of orange and lavender reduce anxiety mood in a dental office. Physiology and Behavior. 86, 92-95.

Lis-Balchin, M., Hart, S., 1999. Studies of the mode action of the essential oil of lavender (Lavandula angustifolia). Phytother. Res. 13, 540-543.

Louis, M., Kowalski, S.D., 2002. Use of aromatherapy with hospice patients to decrease pain, anxiety and depression and to promote an increased sense of well-being. Am. J. Hospice Palliative Care 19, 381-386.

MacTavish, H., Harris, D., 2002. A case study comparing nonUK lavender/lavandin production and peppermint/spearmint with UK production techniques and costs, ADAS Consulting Ltd. Available at: http://www.uicnmed.org/nabp/web/ documents/Essential\%20oils\%20study\%20-\%20UK.pdf

Najafian, S., Rowshan, V., Tarakemeh, A., 2012. Comparing essential oil composition and essential oil yield of Rosmarinus officinalis and Lavandula angustifolia before and full flowering stages. Int. J. Appl. Biol. and Pharm. Tech. 3, 212-218.

Paul, J.P., Brophy, J.J., Goldsack, R.J., Fomtaniella, B., 2004. Analysis of volatile compounds of Lavandula canariensis
(L.) Mill., a Canary Islands endemic species, growing in Australia. Biochem. Syst. Ecol. 32, 55-62.

Peterson, L., 2002. The Australian lavender industry. A review of oil production and related products, Rural Industries Research and Development Corporation. Australian Government. RIRDC publication No. 02-052.

Pitman, V., 2004. Aromatherapy: a practical approach. Nelson Thornes, pp. 111.

Porter, N. G., Shaw, M. L., Hurndell, L. C., 1982. Preliminary studies of Lavender as an essential oil crop for New Zeland. New Zeland J. Agric. Res. 25, 389-394. Avalable at: http:// www.tandfonline.com/doi/abs/10.1080/00288233.1982.104 17902\#preview

Renaud, E.N.C., Charles, D.J., Simon, J.E., 2001. Essential oil quantity and composition from 10 cultivars of organically grown lavender and lavandin. J. Essent. Oil Res. 13(4), 269273.

Sabara, D., Kunicka-Styczynska, A., 2009. Lavender oil flavoring or active cosmetic ingredients? Food Chem. Biotech. 73, 33-41.

Sell, Ch., 2006. The chemistry of fragrances. From perfumer to consumer, $2^{\text {nd }}$ edition. RSC Publishing, pp. 43.

Shafaghat, A., Salimi, F., Amani-Hooshyar, V., 2012. A phytochemical and antimicrobial activity of Lavandula officinalis leaves and stems against some pathogenic microorganisms. J. Med. Plant Res. 6, 455-460.

Tucker, A.O., Maciarello, M.J., Angell, S., Espaillat, J.R., French. E.C., 1993. The essential oil of L. $x$ hybrida Balb. ex Ging., a distinct hybrid from L. $x$ heterophylla Poir. (Labiate). J. Essen. Oil Res. 5, 443-445.

Wesolowska, A., Jadczak, D., Grzeszczuk, M., 2010. Influence of distillation time on the content and composition of essential oil isolated from lavender (Lavandula angustifolia Mill.). Herba Polonica 56, 24-36. Available at: http://www. herbapolonica.pl/magazines-files/9535420-art.3-3-2010.pdf

Wogiatzi, E., Papachatzis, A., Kalorizou, H., Tzalahani, A., 2011. Analysis of Lavandula hybrid essential oils growing in Greece, University of Craiova 16, 488-491. Available at: http://www.anucraiova.3x.ro/cont/2011/Wogiatzi.pdf

Zhekova, G., Nedkov, N., 2010. Quantitative changes in major components of lavender oil during the distillation process. Agric. Sci. Technol. 2, 26-28. 


\title{
Резиме
}

\section{Влијание на времетраењето на дестилацијата на свежи и на суви цветови врз составот на етеричното масло од култивиран лавандин од Република Македонија}

\author{
Марија Карапанџова*, Ивана Цветковиќ, Ѓшше Стефков, Влатко Стоименов, \\ Мартин Црвенов, Светлана Кулеванова \\ Институт за Фармакогнозија, Фармацевтски Факултет, Универзитет „, Св. Кирил и Методиј“, Скопје, \\ Република Македонија
}

Клучни зборови: Lavandula intermedia, Lamiaceae, GC/FID/MS, времетраење на хидродестилација, време на сушење.

Главната цел на оваа студија беше да се анализира составот на етеричното масло од култивиран лавандин (Lavandula x intermedia Emeric ex Loisel., Lamiaceae) во Република Македонија и да се процени влијанието на сушењето на растителниот материјал и времетраењето на дестилацијата врз составот на маслото. Со хидродестилација на свежо набрани и исушени цветови на лавандин во Клевенџер апарат беа добиени 4 различни етерични масла во зависност од времето на дестилацијата (30 минути и 2 часа). Со GC/FID/MS анализа беа идентификувани вкупно 56 компоненти што претставува 96,57\% - 98,23\% од вкупното масло. Доминанти компоненти во анализираните етерични масла беа: линалол (од 35,23\% до 42,24\%), борнеол (од 12,28\% до 16,68\%) и терпинен4-ол (од 4,44\% до 5,62\%). Содржината на 1,8-цинеол варираше од 3,99\% до 8,42\%, додека содржината на камфор беше помеѓу $5,96 \%$ и 7,04\%. Линалил ацетат беше присутен во количини од 1,26\% до 3,21\%. Неочекувано, времетраењето на дестилација незначително влијаеше на составот на етеричните масла. Беа забележани неколку разлики во етеричните масла добиени со 30 минутна дестилација, главно во содржината на борнеол (13,71\% во масло дестилирано од свежи цветови и $16,68 \%$ во масло од суви цветови), додека содржината на другите соединенија беше речиси непроменета. Независно, хемискиот состав на изолираните етерични масла не е во согласност со меѓународните стандарди барања за составот на етеричните масла од лавандин. 


\title{
HPLC and UV-spectrophotometry analysis of flavonoids in spray-dried and freez-dried extracts of Teucrium polium $\mathbf{L}$. (Lamiaceae)
}

\author{
Gjoshe Stefkov $^{1 *}$, Marija Karapandzova ${ }^{1}$, Marina Stefova $^{2}$, Vassya Bankova ${ }^{3}$, \\ Svetlana Kulevanova ${ }^{1}$ \\ ${ }^{1}$ Institute of Pharmacognosy, Faculty of Pharmacy, University Ss Cyril and Methodius, Skopje, Republic of Macedonia \\ ${ }^{2}$ Institute of Chemistry, Faculty of Natural Sciences and Mathematics, University Ss Cyril and Methodius, Skopje, \\ Republic of Macedonia \\ ${ }^{3}$ Department of organic chemistry, Centre for Phytochemistry, BAN, Sofia, Republic of Bulgaria
}

Received: September 2012, Accepted: November 2012

\begin{abstract}
The aim of the study was identification and determination of the content of flavonoids in dry extracts of Teucrium polium, collected from Republic of Macedonia. Two different drying procedures were used, freeze and spray draying. In freeze-dried (FDE) and spray-dried (SDE) extracts of aerial parts of T. polium five flavone aglycones (luteolin, apigenin, cirsiliol, cirsimaritin and cirsilineol) were identified by HPLC method, on the base of retention times and UV spectral data of the components of the extracts in comparison to the authentic samples of flavonoids. Additionally, seven glycosides of apigenin and luteolin were tentatively identified. No significant differences in the composition nor in the content of identified flavonoids were found between both extracts. The content of total flavonoids determined by UV-spectrophotometry with $\mathrm{AlCl}_{3}$ was $72.8 \pm 0.62 \mathrm{mg} \mathrm{Lut} / \mathrm{g}$ and $73.34 \pm 0.53 \mathrm{mg} \mathrm{Lut} / \mathrm{g}$ in FDE and SDE extract of $T$. polium, respectively.
\end{abstract}

Key words: Teucrium polium, freeze-dried extract, spray-dried extract, flavonoids, HPLC analysis, total flavonoids

\section{Introduction}

Teucrium polium L. (Lamiaceae) is widely distributed wild-growing plant in Republic of Macedonia (RM) (Micevski, 1998) and abounds in southwestern Asia, Europe, and North Africa (Mashreghi and Niknia, 2012). This flowering perenial small shrub can grow up to $30 \mathrm{~cm}$ and has a callous white exterior. Infusion of the leaves and flowers is consumed as a appetite stimulating beverage. Some biological and therapeutic effects have been reported for the plant such as anti-oxidant (Kadifkova Panovska et al., 2005; Ardestani et al., 2008; Esmaeili et al., 2009), anti-inflammatory (Tariq et al., 1989; Capasso et al., 1983),

\footnotetext{
*gstefkov@yahoo.com
}

anti-nociceptive (Baluchnejadmojarad et al., 2005; Abdollahi et al., 2003), anti-pyretic (Autore et al., 1984), antimicrobial (Autore et al., 1984; Zerroug et al., 2011), hypolipidemic (Rasekh et al., 2001, Esmaeili and Yazdanparast, 2004; Stefkov et al., 2011), hepatoprotective (Panovska et al., 2007), cytotoxic and apoptotic effects (Rajabalian et al., 2008). It is also found that protects against ethanolinduced gastric mucosal damage (Mashreghi and Niknia, 2012).

Even so, there is a presence of different classes of secondary metabolites, such as diterpenes (Malakov and Papanov, 1983; Marquez and Valverde, 1979), essential oil (Cozzani et al., 2005; Moghtader, 2009; Kabouche et al., 2007), phenylethanoid glycosides (Oganesyan et al.,1991), etc, probably the most important group of compounds in $T$. polium are the flavonoids. Mainly, flavone glycosides with 
highly methylated aglycons are identified until now (Verykokidou-Vitsaropoulou and Vajias, 1986; Rizk et al., 1986; Kawashty et al., 1999; Harborne et al., 1986; Sharififar et al., 2009). Recently was published that freeze-dried extract of T. polium that contain flavonoids posses insulinotropic and antihyperglycemic effects (Stefkov et al., 2011). It is known that freeze-draying or lyophilisation or cryodesication is dehydratation process typically used to preserve a perishable material or make the material more convenient for transport. Freeze-draying works by freezing the material and then reducing the surrounding pressure to allow the frozen water in the material to sublimate directly from the solid phase to the gas phase. Spray-drying is a method of producing a dry powder from a liquid or slurry by rapidly drying with hot gas. This is the preferred method of drying of many thermally-sensitive materials such as food and pharmaceuticals. Today, freeze-dried and spray-dried extracts are the preferable forms of dry extracts in production of herbal medicinal products. Spray-dried extracts are suitable for production of cold water soluble tea and herbal extracts, hot water soluble tea, industrial use for the food and beverage industries, dry sugar mixes, "Ready to Drink" tea beverages, various food products, and tea powder blends like "2 in 1" or "3 in 1" milk mixes. Freeze dried extracts are mainly hot water soluble, suitable for consumer packs of high value products.

Freeze- and spray-drying are different process and works on different ways. The aim of the present study is analysis of flavonoids in dry extracts of T. polium, obtained by two methods of draying, as a part of the first step of eventual standardization of these herbal preparations for further use in production of medicinal products.

\section{Material and methods}

\section{Plant material}

The over-ground parts of the flowering plant Teucrium polim (20-25 $\mathrm{cm}$ from the top) were collected during the summer in 2007 near v. Koleshino, south-east part of R. Macedonia. The plant material was air dried, packed in paper bags and kept in a dark and cool place until analysis. Plant identity was verified and voucher specimens were deposited at the Institute of Pharmacognosy, Faculty of Pharmacy, Skopje, RM.

\section{Reagents and authentic samples}

Reagents of HPLC purity were purchased from Sigma Chemical Co. (Germany). Authentic substances: apigenin and luteolin were products of Extrasynthese (France) and cirsimaritin, cirsilineol and cirsiliol were kindly donated by Dr. B. Voirin from the Laboratoire de Phytochimie, U. E. R. des Sciences de la Nature, Université Claude Bernard Lyon, France.

\section{Preparation of plant extracts}

A quantity of $5 \mathrm{~g}$ of plant material was submitted to hydroalcoholic extraction, in $500 \mathrm{ml}$ ethanol $70 \%(\mathrm{~V} / \mathrm{V})$. The extractions were made with constant mixing on magnetic stirrer for $24 \mathrm{~h}$. To obtain a solid substance, the alcoholic extracts were concentrated in a rotary evaporator to only water residue remained. The concentrated solution was divided in two equal portions.

First portion was spray-dried under following conditions: inlet temperature $110^{\circ} \mathrm{C}$, outlet temperature $69^{\circ} \mathrm{C}$, pump activity $30 \%$, flow rate of extract $8 \mathrm{ml} \mathrm{min}^{-1}$, and aspiration $100 \%$. Atomization pressure was 1.5 bars. This led to obtain spray-dried extract (SDE) of T. polium. The second portion of concentrated extract was freeze-dried on -36 ${ }^{\circ} \mathrm{C}$ under $12 \mathrm{~Pa}$ pressure, $12 \mathrm{~h}$, after previous freezing at $-80{ }^{\circ} \mathrm{C}, 30$ minutes. This led to obtain freeze-dried extract (FDE) of T. polium.

\section{HPLC analysis}

Flavonoid aglycones and glycosides in dried extracts were identified by the HPLC method, using a Varian HPLC system equipped with a ternary pump Model 9012 and UV diode-array detector Model 9065. A reverse phase column C18 (250 x $4.6 \mathrm{~mm}, 5 \mu \mathrm{m}$ particles) was used. The column was stabilized in thermostat on $35^{\circ} \mathrm{C}$ with heater of column (CH-30) and temperature controller (TC-45). The mobile phase consisted of $\mathrm{H}_{2} \mathrm{O}$ with $\mathrm{pH}$ adjusted to 3 with $\mathrm{H}_{3} \mathrm{PO}_{4}(\mathrm{~A})$ and $\mathrm{CH}_{3} \mathrm{CN}(\mathrm{B})$, and the elution program for extracts screening was the following: $0-5 \min 85 \% \mathrm{~A} ; 10$ $20 \min 80 \%$ A; $25-30 \min 75 \%$ A; $40-45 \min 65 \%$ A; 50 $55 \mathrm{~min} 55 \mathrm{~A}$; and $65-70 \mathrm{~min} 35 \mathrm{~A}$. The flow rate was $1 \mathrm{ml}$ $\mathrm{min}^{-1}$, the temperature was set to $35^{\circ} \mathrm{C}$ and the injection volume was $20 \mu \mathrm{l}$ (Stefkov, 2006).

Part of the dried extracts were dissolved in appropriate amount of methanol for HPLC analysis. The elution was monitored in the whole UV range and the chromatograms for flavones screening were best seen at $348 \mathrm{~nm}$, which is in the region where flavones exhibit an absorption maximum. Identification was made according to the retention times and UV spectra of the components compared to those of authentic samples of flavonoids. Semi-quantification of flavones was performed comparing the peak area of flavones in the HPLC chromatograms at $348 \mathrm{~nm}$.

\section{$U V$-spectrophotometry of total flavonoids}

The content of total flavonoid was determined using modified UV-spectrophotometric method for determination of flavonoids by Ph.Eur.7. $10 \mathrm{mg}$ of dry SDE or FDE extracts were hydrolyzed in $50 \mathrm{ml}$ acetone with $2 \mathrm{ml}$ conc. $\mathrm{HCl}$ in a presence of $0.5 \mathrm{ml} 10 \%$ solution of urotropine, 1 h. After cooling the mixture was transferred to $50 \mathrm{ml}$ volumetric flask and filled up with acetone. $20 \mathrm{ml}$ of this were transferred into separating funnel and after adding $20 \mathrm{ml}$ water extracted with ethyl acetate, $3 \times 15 \mathrm{ml}$. Ethyl acetate 
Table 1. Identified flavonoids in spray-dried (SDE) and freez-dried extract (FDE) of Teucrium polium

\begin{tabular}{|c|c|c|c|c|}
\hline Flavone & Structure & $\operatorname{SDE}\left(t_{R}\right)$ & $\operatorname{FDE}\left(t_{\mathrm{R}}\right)$ & $\mathrm{St}\left(\mathrm{t}_{\mathrm{R}}\right)$ \\
\hline Apigenin-glycoside & - & 5.80 & 5.81 & - \\
\hline Luteolin-glycoside & - & 14.30 & 14.35 & - \\
\hline Luteolin-glycoside & - & 15.41 & 15.47 & - \\
\hline Apigenin-glycoside & - & 16.53 & 16.57 & - \\
\hline Apigenin-glycoside & - & 17.74 & 17.79 & - \\
\hline Apigenin-glycoside & - & 18.80 & 18.84 & - \\
\hline Apigenin-glycoside & - & 20.67 & 20.70 & - \\
\hline Luteolin & 3',4',5,7-tetrahydroxyflavone & 31.35 & 31.39 & 31.35 \\
\hline Apigenin & 4',5,7-trihydroxyflavone & 41.20 & 41.23 & 41.21 \\
\hline Cirsiliol & 3',4',5-trihydroxy-6,7-dimethoxyflavone & 43.24 & 43.28 & 43.25 \\
\hline Cirsimaritin & 4',5-Dihydroxy-6,7-dimethoxyflavone & 52.20 & 52.22 & 52.23 \\
\hline Cirsilineol & 4',5-dihydroxy-3',6,7-trimethoxyflavone & 53.70 & 53.74 & 53.72 \\
\hline
\end{tabular}

St - mixture of standard substances of flavonoids

fractions were collected together, washed with water, $3 \mathrm{x}$ $25 \mathrm{ml}$, dried with anhydrous $\mathrm{Na}_{2} \mathrm{SO}_{4}$, filtrated into another $50 \mathrm{ml}$ volumetric flask and filled up with ethyl acetate. 10 $\mathrm{ml}$ of this was used for developing complex with $1 \mathrm{ml} \mathrm{Al-}$ $\mathrm{Cl}_{3}$ in $25 \mathrm{ml}$ volumetric flask, filled up with acetic methanol. The absorbance was measured after $30 \mathrm{~min}$ at $390 \mathrm{~nm}$, against the same prepared solution without $\mathrm{AlCl}_{3}$ used as a blank. The content of total flavonoids was expressed in term of luteolin equivalent (mg Lut / g extract). All meausures were repeated three times.

\section{Results and discussion}

Spray-dried extract of T. polium (SDE) was dry, pale green, amorphous powder with characteristic smell and extremely bitter taste, with $3.73 \%$ moisture. Freez-dried extract (FDE) was dry, dark green powder with characteristic smell, extremely bitter taste and 3.27\% moisture.

The HPLC analysis of dissolved dry extract in methanol $\left(1 \mathrm{mg} \mathrm{ml}^{-1}\right)$ and comparison of the retention times and UV spectral data of selected picks with the appropriate data obtained for standard substances showed presence of 5 different flavones in both dried extracts of T. polium and seven glycosides of apigenin and luteolin (Table 1). The free flavone aglycones could be easily identified as luteolin, apigenin, cirsiliol, cirsimaritin and cirsilineol. Identification of the flavone-glycosides was made tentatively as apigenin- and luteolin-glycosides, identified in both, SDE and FDE, extracts of $T$. polium, recognized by comparing the $\mathrm{UV}$-spectral data with literature and previously published data (Andersen and Markham, 2006). The obtained HPLC chromatograms are presented in Fig. 1.

The obtained results showed no differences in the composition of flavonoids (Table 1, Fig. 1.), in both dry extracts of $T$. polium identical free flavones and flavone glycosides were identified. Semi-quantitative analysis of peak area of the components in the extracts have shown almost identical abundance of identified flavonoids (Table 2).

Table 2. Semi-quantitative HPLC analysis of flavonoids in spray-dried (SDE) and freez-dried extract (FDE) of Teucrium polium

\begin{tabular}{lcc}
\hline \hline Flavone & SDE & FDE \\
\hline Apigenin-glycoside & + & + \\
Luteolin-glycoside & + & + \\
Luteolin-glycoside & + & + \\
Apigenin-glycoside & + & + \\
Apigenin-glycoside & + & + \\
Apigenin-glycoside & + & + \\
Apigenin-glycoside & + & + \\
Luteolin & + & + \\
Apigenin & +++ & +++ \\
Cirsiliol & +++ & +++ \\
Cirsimaritin & + & + \\
Cirsilineol & tr & tr \\
\hline
\end{tabular}

$(+)$ - present; $(+++)$ - dominate; $\operatorname{tr}-$ trace amounts

\section{The content of total flavonoids}

Determination of the content of flavonoids can be made by different methods and most often HPLC or UVspectrophotometry with $\mathrm{AlCl}_{3}$ (complex-making reagent) are used. In case when appropriate authentic substances of flavonoids were not commercially available such it was the case with $T$. polium flavone glycosides, UV-spectrophotometry was chosen as more appropriate. The content of flavonoids was expressed in terms of luteolin equivalent (the standard curve equation of luteolin was: $\mathrm{y}=0.0132+$ $\left.0.0044 ; \mathrm{R}^{2}=0.9993\right), \mathrm{mg}$ Lut/g extract. The obtained results showed no significant differences in the content of to- 


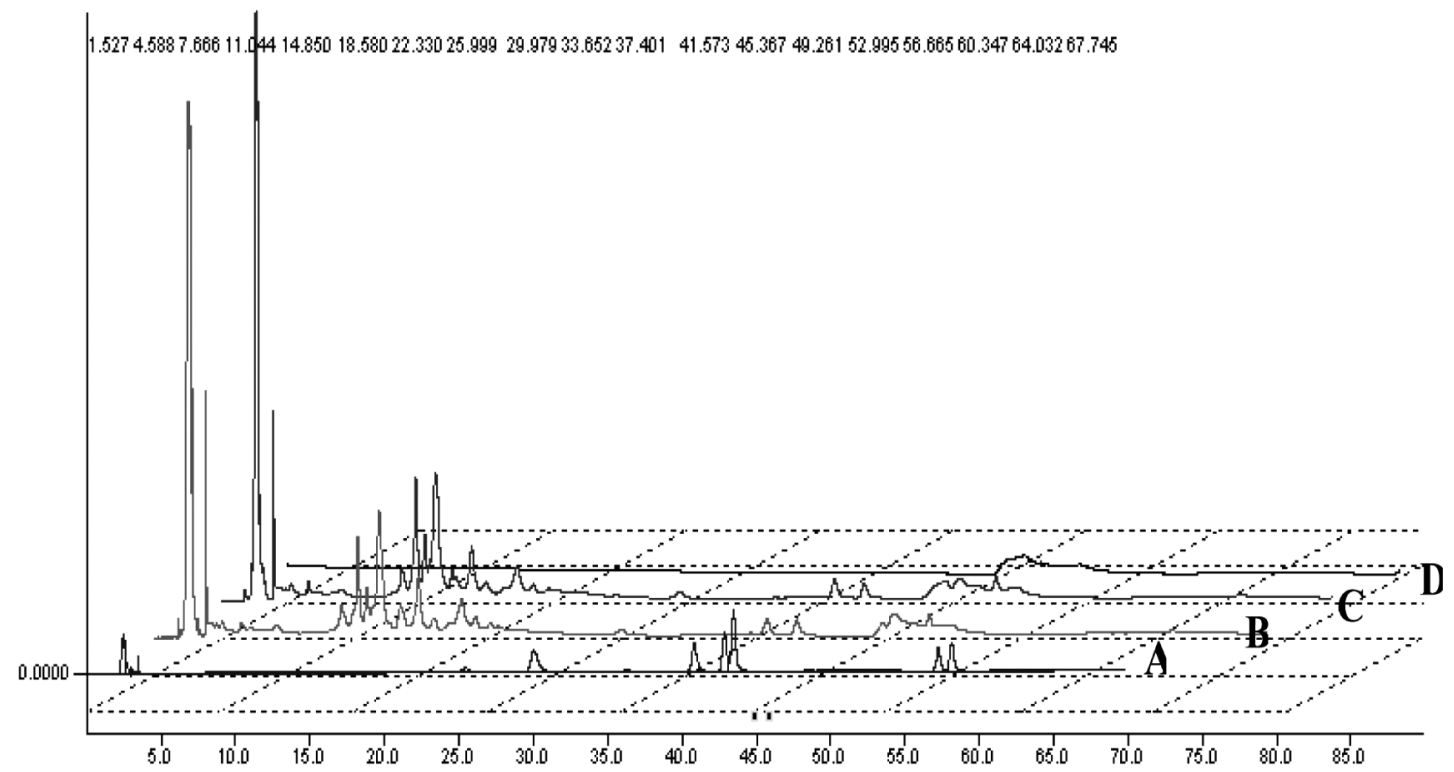

Fig. 1. HPLC chromatograms of mixture of standard substances (A), SDE extract (B), FDE extract (C) and blank (D).

tal flavonoids as $72.8 \pm 0.62 \mathrm{mg} \mathrm{Lut} / \mathrm{g}$ and $73.34 \pm 0.53 \mathrm{mg}$ Lut/g was found in FDE and SDE extract of T. polium, respectively. These are the first results on content of total flavonoids in dry extract of T. polium. Previously, it was reported that dried aerial parts of $T$. polium from RM contain $0.2 \%$ of total flavonoids, determined by UV-spectrophotometry (Kadifkova Panovska et al., 2005).

\section{Conclusion}

In freeze-dried (FDE) and spray-dried (SDE) extracts of aerial parts of T. polium five flavone aglycones (luteolin, apigenin, cirsiliol, cirsimaritin and cirsilineol) were identified by HPLC method, on the base of retention times and UV spectral data of the components of the extracts in comparison to the authentic samples of flavonoids. Additionaly seven glycosides of apigenin and luteolin were tentatively identified. No differences in the composition or in the semi-quantitative abundance of identified flavonoids were found between both extracts, in spite of differences in draying procedure. The content of total flavonoids determined by UV-spectrophotometry with $\mathrm{AlCl}_{3}$ was $72.8 \pm$ $0.62 \mathrm{mg} \mathrm{Lut} / \mathrm{g}$ and $73.34 \pm 0.53 \mathrm{mg} \mathrm{Lut} / \mathrm{g}$ in FDE and SDE extract of $T$. polium, respectively.

\section{References}

Abdollahi, M., Karimpour, H., Monsef-Esfehani, H.R., 2003. Antinociceptive effects of Teucrium polium L. total extract and essential oil in mouse writhing test, Pharmacol. Res. 48, 31-35.

Andersen, Q.M., Markham, K.R., 2006. FLAVONOIDS, Chemistry, Biochemistry and Applications, Taylor \& Francis Group, ISBN 0-8493-2021-6. Accessed at: http://www.uctm-biotechnology. org/Flavonoids.pdf
Ardestani, A., Yazdanparast, R., Jamshidi, S., 2008. Therapeutic effects of Teucrium polium extract on oxidative stress in pancreas of streptozotocin-induced diabetic rats, J. Med. Food 11, 525-532.

Autore, G., Capasso, F., De Fusco, R., Fasulo, M.P., Lembo, M., Mascolo, N. and Menghini, A., 1984. Antipyretic and antibacterial actions of Teucrium polium (L.)., Pharmacol Res Commun. 16, 21-29.

Baluchnejadmojarad, T., Roghani, M. Roghani-Dehkordi, F., 2005. Antinociceptive effect of Teucrium polium leaf extract in the diabetic rat formalin test, J. Ethnopharmacol. 97, 207210.

Capasso, F., Cerri, R., Morrica, P. and Senatore, F., 1983. Chemical composition and anti-inflammatory activity of an alcoholic extract of Teucrium polium L., Boll. Soc. Ital. Biol. Sper. 59, 1639-1643.

Cozzani, S., Muselli, A., Desjobert, J., Bernardini, A., Tomi, F., Casanova, J., 2005. Chemical composition of essential oil of Teucrium polium subsp.capitatum (L.) from Corsica, Flavour and Fragrance Journal 20 (4), 436-441.

Esmaeili, M.A. and Yazdanparast, R., 2004. Hypoglycaemic effect of Teucrium polium: studies with rat pancreatic islets, J. Ethnopharmacol. 95, 27-30.

Esmaeili, M.A., Zohari, F., Sadeghi, H., 2009. Antioxidant and protective effects of major flavonoids from Teucrium polium on beta-cell destruction in a model of streptozotocin-induced diabetes, Planta Med. 75, 1418-1420.

European pharmacopoeia $7^{\text {th }}$ edition, 2010. Concil of Europe, Strasbourg.

Harborne, J.B., Tomas-Barberan, F.A., Williams C.A., Gil, M.I., 1986. A chemotaxonomic study of flavonoids from European Teucrium species, Phytochemistry 25 (12), 2811-2816.

Kabouche, A., Kabouche, Z., Ghannadi, A., Sajjadi, S.E., 2007. Analysis of the essential oil of Teuctrium polium ssp. aurasiaticum from Algeria, J. Essent. Oil. Res. 19, 44-46.

Kadifkova Panovska, T., Kulevanova, S., Stefova, M., 2005. In vitro antioxidant activity of some Teucrium species 
(Lamiaceae), Acta Pharm. 55(2), 207-14.

Kawashty S.A., Gamal El-Din E.M., Saleh N.A.M., 1999. The flavonoid chemosystematics of two Teucrium species from Southern Sinai, Egypt, Biochemical Systematics and Ecology 27, 657-660.

Malakov, P.Y., $\quad$ Papanov, G.Y., 1983. Furanoid diterpenes from Teucrium polium, Phytochemistry 22 (12), 2791-2793.

Marquez, C., Valverde, S., 1979. A new clerodane diterpene from Teucrium polium L., J. Chem. Soc., Perkin Trans. 1, 2526-2527. DOI: 10.1039/P19790002526

Mashreghi, M., and Niknia, S., 2012. The Effect of Peganum harmala and Teucrium polium Alcoholic Extracts on Growth of Escherichia coli O157, Jundishapur J Microbiol. 5(3), 511-515. DOI: $10.5812 / \mathrm{jjm} .3665$

Micevski, K., 1998. Flora of the Republic of Macedonia, Macedonian Academy of Science and Art (Flora na Republika Makedonija, Makedonskata akademija na naukite i umetnostite), Skopje, Republic of Macedonia.

Moghtader, M., 2009. Chemical composition of the essential oil of Teucrium polium L. from Iran, American-Eurasian J. Agric. \& Environ. Sci. 5 (6), 843-846. Accessed at: http:// www.idosi.org/aejaes/jaes5(6)/18.pdf

Oganesyan, G.B., Galstyan, A.M., Mnatsakanyan, V.A., Shashov, A.S., Agababyan, P.V., 1991. Phenilpropanoid glycosides of Teucrium polium, Chemistry of natural compounds 27 (5), 556-559. DOI: 10.1007/BF00630353/

Panovska, T.K., Kulevanova, S., Gjorgoski, I., Bogdanova, M., Petrushevska, G., 2007. Hepatoprotective effect of the ethyl acetate extract of Teucrium polium L. against carbontetrachlorideinduced hepatic injury in rats, Acta Pharm. 57, 241-248.
Rajabalian, S., 2008. Methanolic extract of Teucrium polium L. potentiates the cytotoxic and apoptotic effects of anticancer drugs of vincristine, vinblastine and doxorubicin against a panel of cancerous cell lines. Exp. Oncol. 30, 133-138.

Rasekh, H.R., Khoshnood-Mansourkhani, M. J., Kamalinejad, M., 2001. Hypolipidemic effects of Teucrium polium in rats, Fitoterapia 72, 937-939.

Rizk, A.M, Hammouda, F.M, Rimpler, H., Kamel, A., 1986. Iridoids and flavonoids of Teucrium polium herb, Planta Med. (2), 87-88.

Sharififar, F., Dehghn-Nudeh, G., Mirtajaldini, M., 2009. Major flavonoids with antioxidant activity from Teucrium polium L., Food Chemistry 112, 885-888.

Stefkov, G., 2006. Pharmacognostical investigations on Teucrium polium L. and the other representatives form the genus Teucrium in the flora of Republic of Macedonia, MSci thesis, Faculty of Pharmacy, University Ss Cyril and Methodius, Skopje, Republic of Macedonia.

Stefkov, G., Kulevanova, S., Miova, B., Dinevska-Kjovkarovska, S., Mølgaard, P., Jäger, A.K., Josefsen, K., 2011. Effects of Teucrium polium spp. capitatum flavonoids on the lipid and carbohydrate metabolism in rats. Pharm Biol. 49 (9),88592.

Tariq, M., Ageel, A.M., al-Yahya, M.A., Mossa, J. S. and al-Said, M.S., 1989. Anti-inflammatory activity of Teucrium polium, Int. J. Tissue React. 11, 185-188.

Verykokidou-Vitsaropoulou, E. and Vajias C., 1986. Methylated Flavones from Teucrium polium, Planta Med. 5, 401-402.

Zerroug, M.M., Zouaghi, M., Boumerfeg, S., Baghiani, A., Nicklin, J. Arrar, L., 2011. Antibacterial Activity of Extracts of Ajuga Iva, and Teucrium polium, Advances in Environmental Biology 5(2), 491-495.

\title{
HPLC and UV-спектрофотометриска анализа на флавоноиди во суви екстракти од Teucrium polium L. (Lamiaceae), добиени со спреј сушење и со лиофилизација
}

\author{
Ѓоше Стефков ${ }^{1 *}$, Марија Карапанџова ${ }^{1}$, Марина Стефова ${ }^{2}$, Васја Банкова $^{3}$, \\ Светлана Кулеванова ${ }^{1}$
}

\author{
${ }^{1}$ Институт за фармакогнозија, Фармаиевтски факултет, Универзитет „Св. Кирил и Методиј“, \\ Скопје, Република Македонија \\ ${ }^{2}$ Институт за хемија, Природно-математички факултет, Универзитет „Св. Кирил и Методиј“, \\ Скопје, Република Македонија \\ ${ }^{3}$ Департмент за органска хемија, Центар за фитохемија, БАН, Софија, Република Бугарија
}

Клучни зборови: Teucrium polium, лиофилизиран екстракт, спреј-сушен екстракт, флавоноиди, HPLC анализа, вкупни флавоноиди

Цел на испитувањето е идентификација и определување на содржина на флавоноиди во суви екстракти од Teucrium polium, coбран од Република Македонија. Користени се две различни постапки за сушење, постапка со лиофилизација и постапка на спрејсушење. Во лиофилизираните (FDE) и во спреј-сушените (SDE) екстракти од надземните делови на T. polium, co HPLC анализа и врз база на ретенционите вемиња и UV спектралната анализа, идентификувани се пет флавонски агликони (лутеолин, апиге- 
нин, цирсилиол, цирсимаритин и цирсилинеол), во споредба со автентични примероци од флавоноиди. Дополнително, тентативно се идентификувани седум различни хетерозиди на апигенин и лутеолин. Во двата екстракти не се забележани разлики ниту во составот ниту во содржината на идентификуваните флавоноиди. Содржината на вкупните флавоноиди е определена со UVспектрофотометрија со $\mathrm{AlCl}_{3}$ и изнесува $72.8 \pm 0.62 \mathrm{mg} \mathrm{Lut} / \mathrm{g}$ и $73.34 \pm 0.53 \mathrm{mg} \mathrm{Lut} / \mathrm{g}$ во FDE и SDE екстракт од T. polium, соодветно. 


\title{
Effect of prebiotic content on functional and physicochemical properties of Lactobacillus casei loaded chitosan-Ca-alginate microparticles
}

\author{
Tanja Petreska Ivanovska ${ }^{1}, K$ ristina Mladenovska ${ }^{1}$, Zoran Kavrakovski ${ }^{1}$, \\ Liljana Bogdanovska ${ }^{1}$, Anita Grozdanov ${ }^{2}$, Emil Popovski $^{3}$, Lidija Petrushevska-Tozi ${ }^{1 *}$ \\ ${ }^{1}$ Faculty of Pharmacy, University "Ss. Cyril and Methodious", Vodnjanska 17, Skopje, Macedonia \\ ${ }^{2}$ Faculty of Technology and Metallurgy, University "Ss Cyril and Methodius", Rudjer Boskovic 16, Skopje, Macedonia \\ ${ }^{3}$ Faculty of Natural Sciences and Mathematics, University "Ss Cyril and Methodius", \\ Arhimedova 5, 1000 Skopje, Macedonia
}

Received: October 2012; Accepted: November 2012

\begin{abstract}
This study aims to evaluate the influence of different concentrations of fructooligosaccharide (FOS) as prebiotic on functional and physicochemical properties of Lactobacillus casei loaded chitosan-Ca-alginate microparticles prepared by spray-drying method, after preparation and 6-month storage at $4{ }^{\circ} \mathrm{C}$. Prebiotic compound positively influenced the viability of $L$. casei during preparation of the microparticles and in storage conditions, while no significant difference of the probiotic viability was observed when different concentrations of FOS in a range of $1.5-5 \% \mathrm{w} / \mathrm{w}$ were applied. Having in regard that non-significant improvement in the functional and physicochemical properties of the microparticles with increased content of the FOS was observed, the concentration of $1.5 \% w / w$ was recommended as an optimal for preparation of synbiotic loaded microparticles.
\end{abstract}

Keywords: prebiotic, fructooligosaccharide, Lactobacillus casei, synbiotic microparticles

\section{Introduction}

The health benefits associated with the consumption of probiotics and/or synbiotics continuously intensify the production of functional foods or pharmaceuticals. For the probiotics to be able to exert their health effects to the humans, they need to be viable in the product and in the gut. The loss of viability can occur on the shelf, prior to consumption, during the processing procedures and conditions (e.g. moisture, oxygen stress, freezing, drying, etc.) and after the consumption, due to the effect of gastric acid or antimicrobial effects of bile salts solutions. Different techniques of microencapsulation have been successfully used to en-

\footnotetext{
*1ito@ff.ukim.edu.mk
}

hance the viability of the probiotics and they are crucial for commercial exploitation because probiotic cells must remain active in the products until consumption (Anal and Singh, 2007; Rokka and Rantamäki, 2010). As any encapsulation method and coating agent beside advantages possesses certain disadvantages, it is interesting to investigate the role of different prebiotics added to the formulation as potential enhancers of the functional and physicochemical properties of the probiotic formulations. According to the literature data, prebiotics may increase survival of probiotics during processing and storage of the product and when applied in the host (Gibson and Roberfroid, 1995). For a compound to be classified as prebiotic ingredient, it must neither be hydrolyzed nor absorbed in the upper part of the gastrointestinal tract and be a selective substrate for beneficial bacteria in the colon and alter the colonic microflo- 
ra toward a healthier composition (Schrezenmeir and de Vrese, 2001). Ultimately, it is the ability of the probiotics to metabolize prebiotics and remain viable, accompanied with the production of lactic, acetic and other short chain organic acids that may be antagonistic to the pathogenic competitors in the intestine (Roberforid, 2001).

For FOSs there are in vivo data that confirm fulfillment of the criteria for successful prebiotic (Gibson et al., 2004). Short-chain FOSs measurably raised fecal counts of bifidobacteria in healthy humans at reasonable dose regimen of 2.5-5 g/day within 7 days of administration (Bouhnik et al., 2004), while Kapiki et al. (2007) observed significantly higher number of bifidobacteria in the lower intestine of the infants fed with FOSs. Kunová et al. (2011) have recently reported the ability of lactobacilli strains both of commercial and human origin to utilize the most commonly used prebiotic oligosaccharides with the best growth on inulin followed by lactulose and raffinose. The stabilizing effects of prebiotics in probiotic products during freezedrying, spray-drying and storage have been also reported (Corcoran et al., 2004; Desmond et al., 2005; Schwab et al., 2007).

Strains of $L$. casei reportedly utilized FOS to produce lactic and acetic acid (Liong and Shah, 2005b) that may have beneficial effects on human glucose and lipid metabolism. Acetate can reduce the concentration of the serum fatty acids, in this way decreasing glucose utilization by the tissues and inducing insulin resistance (Rizkalla et al., 2000; de Santa Olalla et al., 2009). In addition, FOS has favorable safety profile and it ingestion may be accompanied with few adverse effects (flatulence, cramping, diarrhea), usually minor in nature (Chow, 2002).

Chemical composition, bond types and degree of purity of the prebiotic may affect the synbiotic relationship with the probiotic. Besides generally accepted claim that prebiotics in wide concentration range improve probiotic properties, when one probiotic strain is co-encapsulated with the prebiotic compound, the interaction between them has to be characterized. In this study, the influence of FOS concentration applied on the viability of $L$. casei during microencapsulation and in storage conditions at $4^{\circ} \mathrm{C}$ for 6 months and the physicochemical properties of the microparticles was evaluated.

\section{Materials and methods}

\section{Materials}

Freeze-dried probiotic culture of Lactobacillus casei01 was purchased from Chr. Hansen, Denmark. Prebiotic FOS was supplied from Sigma-Aldrich, USA. Sodium alginate (Protanal LF 10/60 LS, fG 35-45\%), which was kindly donated by IMCD, FMC BioPolymer (USA), was used as an encapsulating agent. For additional coating of spraydried microparticles, chitosan with deacetylation degree $\geq$ $85 \%$ and low viscosity 342 (viscosity of $1 \% w / w$ solution in acetic acid 20-100 mPa s, $\mathrm{M}_{\mathrm{w}} 150 \mathrm{kDa}$ ) (Chitine, France) was used, while for cross-linking procedure, $\mathrm{CaCl}_{2}$ (Merck, Germany). The Man Rogosa Sharpe (MRS) broth, MRS agar and peptone water were purchased from Merck, Germany. All the reagents were of analytical grade.

\section{Microencapsulation of Lactobacillus casei}

The method applied to microencapsulate $L$. case $i$ was described in details in previous study (Petreska Ivanovska et al., 2012). Aqueous dispersion of alginate and $L$. casei with a cell load $c a .12 \log$ cfu/g was spray-dried (nozzle diameter $0.7 \mathrm{~mm}$, aspirator pressure $90 \%$, atomizer pressure $600 \mathrm{Nlh}^{-1}$, flow rate $6 \mathrm{ml} / \mathrm{min}$, inlet temperature $120^{\circ} \mathrm{C}$ and outlet temperature $60^{\circ} \mathrm{C}$ ) (Büchi Mini Spray Dryer B-290, Switzerland) to obtain microparticles, which were subsequently cross-linked and coated in solution of $\mathrm{CaCl}_{2}$ and chitosan in $1 \% w / w$ acetic acid. Prepared microparticles were cured for $3 \mathrm{~h}$, separated by centrifugation at $1500 \mathrm{xg}$ for $10 \mathrm{~min}$, and freeze-dried at $0.070 \mathrm{mbar}$ and $-50{ }^{\circ} \mathrm{C}$ for 24 h (FreeZone Freeze Dry System, Labconco, USA).

In order to investigate the optimal content of FOS in the microparticles, the L. casei-alginate dispersion was supplied with the prebiotic at concentrations of 1.5, 3 and 5\% $w / w$ prior to spray-drying. Further, to analyze the influence of the high temperature associated spray-drying process on the prebiotic activity, two series of microparticles containing the lowest concentration of FOS $(1.5 \% \mathrm{w} / \mathrm{w})$ were prepared. In the first, FOS was added during the coating of the microparticles into solution of chitosan and $\mathrm{CaCl}_{2}$ in $1 \%$ $v / v$ acetic acid and in the second prior to freeze-drying.

\section{Viability assay of encapsulated L. casei}

Viability of encapsulated and co-encapsulated $L$. $c a$ sei during preparation of the microparticles and in storage conditions was determined using plate-count method. The prepared microparticles in the predetermined time intervals were dispersed in phosphate buffer solution $(\mathrm{pH}$ 6.9) until complete release of the probiotic cells at room temperature (Petreska Ivanovska et al., 2012). Then, the suspension was serially diluted in $0.1 \%$ sterile peptone solution and appropriate aliquot was plated in triplicate on selective MRS agar and incubated at $37^{\circ} \mathrm{C}$ under aerobic conditions for $72 \mathrm{~h}$. Afterwards, L. casei was enumerated and the average of the results was expressed as colony-forming units per gram of sample $(\mathrm{cfu} / \mathrm{g})$.

\section{Physicochemical characterization of the L. casei loaded microparticles}

Following physicochemical properties of the $L$. $\mathrm{Ca}$ sei loaded chitosan-Ca-alginate microparticles were determined: particle size distribution, Ca-content, and zetapotential. Particle size measurements were performed immediately after sample preparation. Namely, $50 \mathrm{mg}$ of microparticles of each individual series were dispersed in 5 
$\mathrm{ml}$ deionized water, sonicated for $10 \mathrm{~min}$ in ultrasound bath and then passed through a Mastersizer Hydro 2000G (Malvern Instruments Ltd., UK). Samples were added to circulating filtered water until laser obscuration exceeded $10 \%$. The mean particle size of the microparticles was expressed as $d_{50}$. The zeta-potential of the suspended microparticles previously sonicated for $10 \mathrm{~min}$ in ultrasound bath was determined in $0.1 \mathrm{mM}$ phosphate buffer $(\mathrm{pH} 6.8)$ by dynamic light scattering (Zeta-sizer Nano ZS, Malvern Instruments Ltd., UK). For the calcium content measurement, the microparticles were firstly degraded in concentrated $\mathrm{HNO}_{3}$ by boiling $(2.5 \mathrm{mg} / \mathrm{ml})$ (Mladenovska et al., 2007a; Petreska Ivanovska et al., 2012). The calcium content was determined by atomic emission spectroscopy-inductively coupled plasma (AES-ICP, Varian, USA). All measurements for particle size, zeta potential and Ca-content determination were repeated in triplicate for each formulation and results are reported as averages.

\section{Results and discussion}

\section{Effect of FOS concentration on viability of encapsulated L. casei}

The strains of the main probiotic genera Lactobacillus and Bifidobacterium are known to resist gastric acid, bile salts and pancreatic enzymes, to adhere to colonic mucosa and readily colonize the intestinal tract (Fioramonti et al., 2003), but studies indicate poor survival under GI conditions (Kailasapathy, 2002) and also when added to food products as bioactive components (De Vos et al., 2010). Besides microencapsulation that enables physical separation of the cells from the surrounding environment, the presence of prebiotics may increase the resistance of the probiotics to these environmental factors and promote the growth and health effects of the probiotics.

The concentration range of FOS applied in this study $(1.5-5 \% w / w)$ was selected on the basis of data indicating that FOS is effective in humans at doses under $5 \mathrm{~g} /$ day. In a study of Rao (2001), administration of $5 \mathrm{~g}$ FOS daily resulted in a $1 \mathrm{log}$ increase of the bifidobacteria counts compared to a sucrose placebo, while Kelly claimed that dose of $1.25 \mathrm{~g} /$ day FOS is minimal to provide the bifidogenic effect (Kelly, 2009). The results of the viability of L. casei during the encapsulation and co-encapsulation with FOS $(1.5-5 \% w / w)$ in different steps of preparation are presented in Fig. 1a.

The illustration obviously indicates that after spraydrying, the best survival rate of $L$. casei was obtained when FOS was added at concentration of $1.5 \% \mathrm{w} / \mathrm{w}$, while nonsignificant difference in viability of $L$. casei co-encapsulated with FOS at 1.5, 3 and 5\% $w / w$ was observed after freeze-drying. However, the viability of $L$. casei co-encapsulated with different concentrations of FOS $(1.5-5 \% w / w)$ was significantly higher compared to $L$. casei encapsulated without FOS. The positive effect of FOS results from its hydrocolloid properties (Desai et al., 2004), especially im- portant when cell dehydration is caused by high temperature during spray-drying. Freeze-drying as a hyperosmotic process is also detrimental for the cells. However, hydrophilic carbohydrate molecules may be easily accumulated into the cells, thus preventing the denaturation of the cell proteins that is usually associated with the increased content of salts in the medium (Capela et al., 2006). The formation of hydrogen bonds that ensures stable tertiary structure of the proteins in the absence of water (Leslie et al., 1995 ) is the most likely protective mechanism of the cells by oligosaccharides.
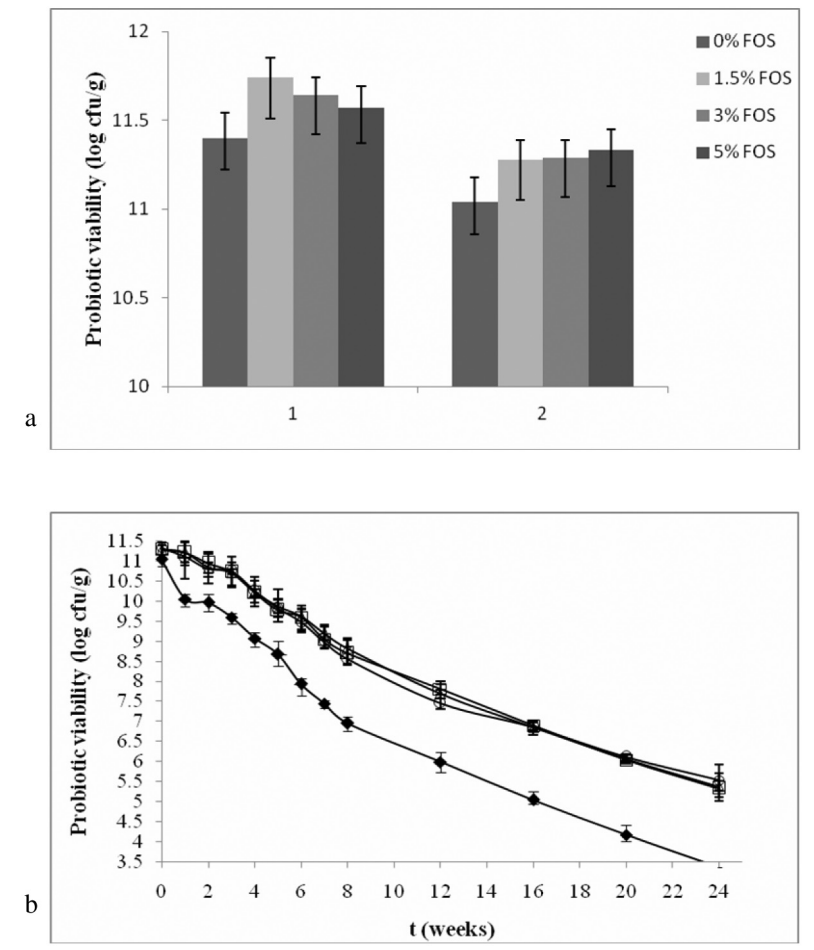

Fig. 1. Viability of Lactobacillus casei: a) during preparation: 1 - after spray-drying; 2 - after freezedrying (viability of the initial suspension was $12.2 \pm 0.46 \log \mathrm{cfu} / \mathrm{g}$ ) and b) during 6-month cold storage of the chitosan-Ca-alginate microparticles: without FOS $(\bullet) ; 1.5 \%(w / w)$ FOS supplied before spray-drying $(\square) ; 3 \%(w / w)$ FOS supplied before spray-drying $(\Delta)$ and 5\% $(w / w)$ FOS supplied before spray-drying $(0)$.

The slight improvement of the probiotic viability is due to the lower stability of FOS under conditions of low $\mathrm{pH}$ and high temperatures, especially when two factors are combined (Huebner et al., 2008; Charalampopoulos and Rastall, 2012). FOS derived from chicory root inulin was found as the most acid-sensitive component $(\mathrm{pH} 2.0$ and 3.0) among wheat bran-derived arabinoxylooligosaccharides and xylooligosasccharides (Courtin et al., 2009), while degradation occurs at processing temperature (60- 
$100{ }^{\circ} \mathrm{C}$ ) and $\mathrm{pH}(2.7-3.3)$ (Matusek et al., 2009). With a view to the $\mathrm{pH}$ of our suspension subjected to spray-drying (5.8-6) and associated high temperature (inlet and outlet temperature of $120^{\circ} \mathrm{C}$ and $60{ }^{\circ} \mathrm{C}$, respectively), partial degradation of the prebiotic FOS is possible.

To overcome eventual hydrolysis by spray-drying, FOS was added during additional coating of the Ca-alginate particles with chitosan and before freeze-drying. The applied modifications have not enhanced the survival rate of the probiotic leading to the conclusion that FOS retains the prebiotic activity under spray-drying conditions. Namely, the reduction in viable cell counts of $L$. casei co-encapsulated with $1.5 \% w / w$ FOS supplied prior to spray-drying, after spray-drying and before freeze-drying was 0.92 logs, 1.39 logs, and $2.14 \operatorname{logs}$ of the initial viability of $12.2 \pm 0.46 \mathrm{log}$ $\mathrm{cfu} / \mathrm{g}$, respectively. Concerning this, Gardiner et al. (2000) and Desmond et al. (2001) claimed that other factors as bacterial strain and species, inoculum type, medium, preadaptation of the culture, are responsible for the viability of the probiotic bacteria subjected to spray-drying, apart from the drying conditions and protective agents.

\section{Effect of FOS concentration on viability of encapsulated L. casei during storage}

Analysis of the relationship probiotic-prebiotic and the role of the prebiotic in the synbiosis may help in the development of new nutraceuticals with prolonged durability. To our knowledge, only few studies evaluated the influence of FOS on the viability of co-encapsulated probiotics in different conditions. Namely, Chen et al. (2005) revealed that co-encapsulation with FOSs and isomaltooligosaccharides enhanced the survival of probiotic strains studied (L. acidophilus, L. casei, B. bifidum, B. longum) during production by extrusion, exposure to acidic and bile salts solutions and 3 months of storage. Ann et al. (2007) concluded that the prebiotic FOS $(1.5 \% v / v)$ positively affected the survival of L. acidophilus ATCC 43121 in the double-coated preparations compared to uncoated and single coated ones produced by hybridization technique. The positive effect of FOS added in probiotic food products was observed after relatively long storage (28 days) in the study of Bozanic et al. (2002) when fermented milks were fortified with high molecular weight FOS such as inulin. Oligofructose enriched reconstituted skim milk showed enhanced survival of six Lactobacillus strains during 4 week storage at 4 ${ }^{\circ} \mathrm{C}$ in comparison to the control (Desai et al., 2004). However, data showing ineffectiveness of inulin and oligofructose as prebiotics have been reported, also. Thus, Drgalic et al. (2005) observed no improvement in the viability of probiotic bacteria in yoghurt containing $1 \% w / v$ inulin. The same was verified by Castro et al. (2009) who used a shortchain oligofructose $(1.4-5 \% \mathrm{w} / \mathrm{v})$ in fermented lactic beverages without significant increase in probiotic viability.

When reviewing our data during 6-month storage of the microparticles at $4{ }^{\circ} \mathrm{C}$, it is obvious that the viability is higher in the microparticles containing FOS (Fig. 1b). In addition, viability assay has shown that the microparticles without FOS retained therapeutic counts of $L$. casei $\left(10^{6}\right.$ $10^{7} \mathrm{cfu} / \mathrm{g}$ ) up to 3 months of cold storage, while the microparticles containing FOS at $1.5 \% w / w$ maintained the therapeutic level of viable cells within 5 months $(6.04 \pm 0.1$ $\log \mathrm{cfu} / \mathrm{g}$ ). The findings are in accordance to the ability of the probiotics to ferment and utilize the prebiotics as energy source (Biedrzycka and Bielecka, 2004). Although, a prebiotic activity of FOS is supposed to be mostly expressed during long-term storage, the results obtained in this study pointed to its most potent effect in the first week of the cold storage. In addition, the strain L. casei-01 survived preferably in the presence of $1.5 \% \mathrm{w} / \mathrm{w}$ FOS, especially in the storage conditions. Increase of the FOS concentration up to $5 \% \mathrm{w} / \mathrm{w}$ did not provide further increase in cell viability (Fig. 1b), thus the concentration above $1.5 \%$ $w / w$ is not economically justified. In the study of Kaplan and Hutkins (2003), FOS was a less usable substrate for the probiotic $L$. paracasei 1195 in the presence of hydrolytic products of the higher oligosaccharides or in the presence of excess glucose, fructose, and sucrose in the assay medium. The divergence of the literature data describing the effect of added prebiotics on probiotic viability can be attributed to a strain-dependant response (Donkor et al., 2007) rather than genera or species confirmed by the time interval need for different prebiotics to stimulate the growth of Lactobacillus and Bifidobacterium species (Huebner et al., 2007).

\section{Effect of FOS on physicochemical properties of the L. Ca- sei loaded microparticles}

In this study, the effect of the concentration of prebiotic FOS on Ca-content of the chitosan-Ca-alginate microparticles was also evaluated. The results obtained indicated that the Ca-content decreased with increasing concentration of FOS in the range of 1.5 to $5 \% w / w$ (Table 1). FTIR studies of the chemical structures and possible interactions among the polymers, alginate and chitosan, cross-linking agent $\mathrm{CaCl}_{2}$, probiotic and prebiotic in the microparticles have confirmed the existence of band $\left(\sim 3360 \mathrm{~cm}^{-1}\right)$ that belongs to the stretching vibrations of the hydroxyl groups of alginate and FOS bonded via hydrogen bonds (data not presented). At higher concentration of FOS, the formation of hydrogen bonds may cause certain conformational changes in the alginate structure, thus less $\mathrm{Ca}$ ions are bond with the carboxylic groups. Considering the similar Ca-content of the synbiotic formulations containing $1.5 \% \mathrm{w} / \mathrm{w}$ FOS supplied before spray-drying, during additional coating and prior to freeze-drying (Table 1), one can conclude that the mechanical stability of the microparticles is not influenced by the preparation step in which FOS would be added to the formulation.

Further, the effect of FOS concentration on the size of $L$. casei loaded microparticles was studied. Micropar- 
Table 1. Physicochemical properties of L. casei loaded chitosan-Ca-alginate microparticles (data points are expressed as means \pm standard deviation of three repeated experiments, $n=3$ )

\begin{tabular}{|c|c|c|c|}
\hline \multirow[b]{2}{*}{ Samples* } & \multicolumn{3}{|c|}{ Physicochemical properties } \\
\hline & $\begin{array}{c}\text { Ca-content } \\
\text { (mg/10 mg particles) }\end{array}$ & $\begin{array}{c}\text { Particle size } \\
\mathrm{d}_{50}(\mu \mathrm{m})\end{array}$ & $\begin{array}{l}\text { Zeta potential } \\
\qquad(\mathrm{mV})\end{array}$ \\
\hline 1 & $0.881 \pm 0.02$ & $9.00 \pm 0.5$ & $44.73 \pm 1.60^{* *}$ \\
\hline 2 & $0.896 \pm 0.02$ & $8.67 \pm 0.4$ & $21.56 \pm 1.10$ \\
\hline 3 & $0.811 \pm 0.03$ & $8.01 \pm 0.4$ & $23.84 \pm 1.22$ \\
\hline 4 & $0.688 \pm 0.02$ & $7.66 \pm 0.2$ & $-33.92 \pm 0.90$ \\
\hline 5 & $0.917 \pm 0.04$ & $8.84 \pm 0.3$ & $-38.14 \pm 1.05$ \\
\hline 6 & $0.880 \pm 0.02$ & $8.52 \pm 0.4$ & $-29.67 \pm 1.31$ \\
\hline
\end{tabular}

*1 - microparticles without FOS;

2 - microparticles prepared with $1.5 \% w / w$ FOS added before spray-drying;

3 - microparticles prepared with $3 \% \mathrm{w} / \mathrm{w}$ added before spray-drying;

4 - microparticles prepared with $5 \% w / w$ FOS added before spray-drying;

5 - microparticles prepared with $1.5 \% w / w$ FOS added during coating / cross-linking procedure;

6 - microparticles prepared with $1.5 \% w / w$ FOS added before freeze-drying.

ticles, smaller in size, are more convenient to be added in food products in order to obtain functional products with favorable sensory and textural properties (O'Riordan et al., 2001). In addition, particles with size less than $10 \mu \mathrm{m}$ are advantageous due to their ability to colonize the lower intestine effectively (Washington et al., 2001) and subsequently to produce positive health effects for the consumer. When comparing the particles containing the same concentration of FOS $(1.5 \% \mathrm{w} / \mathrm{w})$, but added at different preparation steps, non-significant difference in particle size was found. The microparticles without FOS had largest mean diameter, while the microparticles containing 5\% $w / w$ FOS were smallest in size (Table 1). However, the size of the prepared particles supplied with FOS $(1.5,3$ and 5\% $w / w)$ or without FOS is appropriate to provide controlled and targeted release of the probiotic cells in the lower intestine.

Chitosan-Ca-alginate microparticulate system may improve the capacity of the probiotic cells to adhere to the negatively charged intestinal mucosa since the bacterial cells are in general negatively charged (Pelletier et al., 1997). The dominant localization of chitosan in the particle wall that was observed by imaging the chitosan-Ca-alginate particles with FITC-labeled chitosan using confocal laser scanning microscopy (Mladenovska et al., 2007a, b) may produce positively charged microparticles. However, the charge of the prepared particles may be influenced by the concentration of FOS, thus the zeta potential of the particles containing 1.5, 3 and 5\% $w / w$ FOS was determined. The results presented in Table 1 led to the conclusion that favorable alginate-chitosan interaction providing external orientation of the positively charged chitosan was enabled with the presence of FOS up to $3 \% w / w$. The presence of $5 \% w / w$ FOS in the formulation changed the charge to a negative value, probably due to the interaction between the FOS and chitosan. The negative charge of the microparti- cles was also observed when supplemented with $1.5 \% \mathrm{w} / \mathrm{w}$ FOS after spray-drying or prior to freeze-drying. In both ways, the possibility for interaction between chitosan and FOS on the particle surface is increased, thus the positively charged groups of the chitosan became occupied. Having in regard adversely affected surface charge of the particle with the increased content of FOS above 3\% w/w and because no further improvement of the Ca-content and particle size with the increased content of FOS above $1.5 \% \mathrm{w} / \mathrm{w}$ was observed, as an optimal concentration of FOS to be applied in the formulation, $1.5 \% \mathrm{w} / \mathrm{w}$ was chosen.

\section{Conclusion}

The influence of different concentrations of the prebiotic FOS on the viability of chitosan-Ca-alginate loaded $L$. case $i$ and physicochemical properties of the microparticles was studied. The presence of $1.5 \% w / w$ FOS has shown slight improvement in the viability of encapsulated $L$. $c a$ sei during preparation, while the effect was significant during cold storage. However, increased concentration of the prebiotic FOS in the microparticles up to $5 \% w / w$ resulted in no further improvement of the probiotic viability at conditions investigated and physicochemical properties of the microparticles as well. Thus, the probiotic chitosan-Ca-alginate microparticles should be prepared with $1.5 \% \mathrm{w} / \mathrm{w}$ FOS in the dispersion of alginate and L. casei intended for spray-drying, while the synergistic effects of the probiotic L. casei and the prebiotic FOS should be further studied in vitro and in vivo. Further studies are also needed to optimize the concentrations of the polymers and cross-linking agent as factors that may affect the physicochemical properties of the microparticles and viability of $L$. casei under different conditions of the environment. 


\section{Acknowledgments}

This research was financially supported by the Ministry of Education and Science of the Republic of Macedonia (Project No. 13-3583). The authors would like to thank IMCD (UK) for the donation of sodium alginate (Protanal 10/60 LS, FMC BioPolymer).

\section{References}

Anal, A. K., Singh, H., 2007. Recent advances in microencapsulation of probiotics for industrial applications and targeted delivery. Trends Food Sci. Technol. 18, 240-251.

Ann, E.Y., Kim, Y., Oh, S., Imm, J-Y., Park, D-J., Han, K.S., Kim, S.H., 2007. Microencapsulation of Lactobacillus acidophilus ATCC 43121 with prebiotic substrates using a hybridization system. Int. J. Food Sci. Technol. 42, 411-419.

Biedrzycka, E., Bielecka, M., 2004. Prebiotic effectiveness of fructans of different degrees of polymerization. Trends Food Sci. Technol. 15, 170-175.

Bozanic, R., Rogelj, I., Tratnik, L., 2002. Fermentation and storage of probiotic yogurt from goat milk. Dairy 52, 93111.

Bouhnik, Y., Raskine, L., Simoneau, G., Vicaut, E., Neut, C., Flourie, B., Brouns, F., Bournet, F.R., 2004. The capacity of nondigestible carbohydrates to stimulate fecal bifidobacteria in healthy humans:A double-blind, randomized, placebocontrolled, parallel-group, dose response relation study. Am. J. Clin. Nutr. 80, 1658-1664.

Capela, P., Hay, T.K.C., Shah, N.P., 2006. Effect of cryoprotectants, prebiotics and microencapsulation on survival of probiotic organisms in yoghurt and freeze-dried yoghurt. Food Res. Int. 39, 203-211.

Castro, F.P., Cunha, T.M., Ogliari, P.J., Teófilo, R.F., Ferreira, M.M.C., Prudêncio, E.S., 2009. Influence of different content of cheese whey and oligofructose on the properties of fermented lactic beverages: Study using response surface methodology. LWT-Food Sci. Technol. 42, 993-997.

Charalampopoulos, D., Rastall, R.A., 2012. Prebiotics in food. Curr. Opin. Biotechnol. 23, 187-191.

Chen, K.N., Chen, M.J., Liu, J.R., Lin, C.W., Chiu, H.Y., 2005. Optimization of incorporated prebiotics as coating materials for probiotic microencapsulation. J. Food Sci. 70, 260-266.

Chow, J.M., 2002. Probiotics and prebiotics: A brief overview. J. Renal Nutr. 12, 76-86.

Corcoran, B.M., Ross, R.P., Fitzgerald, G.F., Stanton, C., 2004. Comparative survival of probiotic lactobacilli spray-dried in the presence of prebiotic substances. J. Appl. Microbiol. 96, 1024-1039.

Courtin, C.M., Swennen, K., Verjans, P., Delcour, J.A., 2009. Heat and $\mathrm{pH}$ stability of prebiotic arabinoxylooligosaccharides, xylooligosaccharides and fructooligosaccharides. Food Chem. 112, 831-837.

Desai, A.R., Powell, I.B., Shah, N.P., 2004. Survival and activity of probiotics lactobacilli in skim milk containing probiotics. J. Food Sci. 69, FMS557-FMS60.

de Santa Olalla, L.M., Sanchez Muniz, F.J., Vaquero, M.P., 2009. $\mathrm{N}-3$ fatty acids in glucose metabolism and insulin sensitivity. Nutr. Hosp. 24, 113-127.

Desmond, C., Stanton, C., Fitzgerald, G.F., Collins, K., Ross, R.P., 2001. Environmental adaptation of probiotic lactobacilli towards improvement of performance during spray drying. Int. Dairy J. 11, 801-808.

Desmond, C., Corcoran, B.M., Coakley, M., Fitzgerald, G.F., Ross, R.P., Stanton, C., 2005. Development of dairy-based functional foods containing probiotics and prebiotics. Austral. J. Dairy. Technol. 60, 121-126.

De Vos, P., Faas, M.M., Spasojevic, M., Sikkema, J., 2010. Encapsulation for preservation of functionality and targeted delivery of bioactive food components. Int. Dairy J. 20, 292302.

Donkor, O.N., Nilmini, S.L.I., Stolic, P., Vasiljevic, T., Shah, N.P., 2007. Survival and activity of selected probiotic organisms in set-type yoghurt during cold storage. Int. Dairy J. 17, 657665.

Drgalic, I., Tratnik, L., Bozanic, R., 2005. Growth and survival of probiotic bacteria in reconstituted whey. Le Lait: Dairy Sci. Technol. 85, 171-179.

Fioramonti, J., Theodorou, V., Bueno, L., 2003. Probiotics: what are they? What are their effects on gut physiology? Best Pract. Res. Clin. Gastroenterol. 17, 711-724.

Gardiner, G., O'Sulilivan, E., Kelly, J., Auty, M.A.E., Fitzgerald, G.F., Collins, J.K., Ross, R.P., Stanton, C., 2000. Comparative survival rates of human-derived probiotic Lactobacillus paracasei and Lactobacillus salivarius strains during heat treatment spray drying. Appl. Environ. Microbiol. 66, 26052612.

Gibson G.R., Roberfroid M.B., 1995. Dietary modulation of the human colonic microflora: introducing the concept of prebiotics. J. Nutr. 125, 1401-1412.

Gibson, G.R., Probert, H.M., Van Loo, J.A.E., Roberfroid, M.B., 2004. Dietary modulation of the human colonic microbiota: Updating the concept of prebiotics. Nutr. Res. Rev. 17, $257-$ 259.

Huebner, J., Wehling, R.L., Hutkins, R.W., 2007. Functional activity of commercial prebiotics. Int. Dairy J. 17, 770-775.

Huebner, J., Wehling, R.L., Parkhurst, A., Hutkins, R.W., 2008. Effect of processing conditions on the prebiotic activity of commercial prebiotics. Int. Dairy J. 18, 287-293.

Kailasapathy, K., 2002. Microencapsulation of probiotic bacteria: technology and potential application. Curr. Issues Intest. Microbiol. 3, 39-48.

Kapiki, A., Costalos, C., Oikonomidou, C., Triantafyllidou, A., Loukatou, E., Perthrohilou, V., 2007. The effect of a fructooligosaccharide supplemented formula on gut flora of preterm infants. Early Hum. Dev. 83, 335-339.

Kaplan, H., Hutkins, R.W., 2003. Metabolism of fructooligosaccharides by Lactobacillus paracasei 1195 . Appl. Environ. Microbiol. 69, 2217-2222.

Kelly, G., 2009. Inulin-type prebiotics - a review (part 2). Altern. Med. Rev. 14, 36-55.

Kunová, G., Rada, V., Lisová, I., Ročková, Š., Vlková, E., 2011. In vitro fermentability of prebiotic oligosaccharides by lactobacilli. Czech J. Food. Sci. 29, S49-S54.

Leslie, S.B., Israeli, E., Lighthart, B., Crowe, J.H., Crowe, L.M., 1995. Trehalose and sucrose protect both membranes and proteins in intact bacteria during drying. Appl. Environ. Microbiol. 61, 3592-3597.

Liong, M.T. and Shah, N.P. 2005b. Optimization of growth of Lactobacillus casei ASCC 292 and production of organic acids in the presence of fructooligosaccharides and maltodextrin. J. Food Sci. 70, M113-M120.

Matusek, A., Merész, P., Diem Le, T.K., Örsi, F., 2009. Effect of temperature and $\mathrm{pH}$ on the degradation of fructo- 
oligosaccharides. Eur. Food Res. Technol. 228, 355-365.

Mladenovska, K., Raicki, R. S., Janevik, E.I., Ristoski, T., Pavlova, M.J., Kavrakovski Z., Dodov M.G., Goracinova K., 2007a. Colon-specific delivery of 5-aminosalicylic acid from chitosan-Ca-alginate microparticles. Int. J. Pharm. 342 (1-2), 124-136.

Mladenovska, K., Cruaud, O., Richomme, P., Belamie, E., Raicki, R.S., Venier-Julienne, M.-C., Popovski, E., Benoit, J.P., Goracinova, K., 2007b. 5-ASA loaded chitosan-Caalginate microparticles: Preparation and physicochemical characterization. Int. J. Pharm. 345, 59-69.

O’Riordan, K., Andrews, D., Buckle, K., Conway, P., 2001. Evaluation of microencapsulation of a Bifidobacterium strain with starch as an approach to prolonging viability during storage. J. Appl. Microbiol. 91, 1059-1066.

Pelletier, C., Bouley, C., Cayuela, C., Bouttier, S., Bourlioux, P., Bellon-Fontaine, M.-N., 1997. Cell surface characteristics of Lactobacillus casei subsp. casei, Lactobacillus paracasei subsp. paracasei, and Lactobacillus rhamnosus strains. Appl. Environ. Microbiol. 63, 1725-1731.

Petreska Ivanovska, T., Petrusevska-Tozi, L., Dabevska Kostoska, M., Geskovski, N., Grozdanov, A., Stain, C., Stafilov, T., Mladenovska, K, 2012. Microencapsulation of Lactobacillus casei in chitosan-Ca-alginate microparticles using spray- drying method. Maced. J. Chem. Chem. Eng. 31, 115-123.

Rao, V.A., 2001. The prebiotic properties of oligofructose at low intake levels. Nutr. Res. 21, 843-848.

Rizkalla, S.W., Luo, J., Morvarid, K., Chevalier, A., Pacher, N., Gerard, S., 2000. Chronic consumption of fresh but not heated yoghurt improves breath-hydrogen status and shortchain fatty acid profiles: a controlled study in healthy men with or without lactose maldigestion. Am. J. Clin. Nutr. 72, 1474-1470.

Roberfroid, M.B., 2001. Prebiotics: preferential substrates for specific germs? Am. J. Clin. Nutr. 73, 406S-409S.

Rokka, S., Rantamäki, P., 2010. Protecting probiotic bacteria by microencapsulation: challenges for industrial applications. Eur. Food Res. Technol. 231, 1-12.

Schrezenmeir, J., de Vrese, M., 2001. Probiotics, prebiotics, and synbiotics - approaching a definition. Am. J. Clin. Nutr. 73, 361S-364S.

Schwab, C., Vogel, R., Gánzle, M.G., 2007. Influence of oligosaccharides on the viability and membrane properties of Lactobacillus reuteri TMW1.106 during freeze-drying. Cryobiology 55, 108-114.

Washington, N., Washington, C., Wilson, C.G., 2001. Physiological Pharmaceutics - Barriers to Drug Absorption, second ed. Taylor \& Francis, London and New York.

\title{
Резиме
}

\section{Влијание на содржината на пребиотикот врз функционалните и физичко-хемиските својства на цитозан- Са-алгинатните микрочестички со Lactobacillus casei}

\author{
Тања Петреска Ивановска ${ }^{1}$, Кристина Младеновска ${ }^{1}$, Зоран Кавраковски ${ }^{1}$, \\ Лилјана Богдановска ${ }^{1}$, Анита Грозданов ${ }^{2}$, Емил Поповски ${ }^{3}$, \\ Лидија Петрушевска-Този ${ }^{1 *}$
}

\begin{abstract}
IФармацевтски факултет, Универзитет “Св. Кирил и Методиј”, Водњанска 17, Скопје, Македонија ${ }^{2}$ Технолошко-металурики факултет, Универзитет “Св. Кирил и Методиј”, Руѓер Бошковиќ 16, Скопје, Македонија 3Природно-математички факултет, Универзитет “Св. Кирил и Методиј”, Архимедова 5, Скопје, Македонија
\end{abstract}

Клучни зборови: пребиотик, фруктоолигосахарид, Lactobacillus casei, синбиотски микрочестички

Цел на ова истражување е да се оцени влијанието на пребиотикот фруктоолигосахарид врз функционалните и физичкохемиските својства на цитозан-Са-алгинатните микрочестички со Lactobacillus casei во текот на микроинкапсулирањето со примена на методот на распрснување со сушење и при чување на честичките за време од 6 месеци на $4{ }^{\circ} \mathrm{C}$. Притоа, пребиотикот покажа позитивен ефект врз виталноста на $L$. casei, но со зголемување на неговата концентрација во интервалот од $1.5-5 \%$ w/w не беше забележана значајна разлика на виталноста, како во услови на подготовка, така и во услови на чување на честичките. Добиените резултати покажаа дека со зголемување на концентрацијата на фруктоолигосахаридот не доаѓ до значително подобрување на функционалните и физичко-хемиските својства на честичките, од каде произлегува заклучокот дека $1.5 \%$ w/w фруктоолигосахарид претставува оптимална содржина на пребиотикот за подготовка на синбиотските микрочестички. 



\title{
Legal status of the pharmacy practice in the European Union and the Republic of Macedonia
}

\author{
J. Patcheva ${ }^{1 *}$, K. Mladenovska ${ }^{2}$, L. Petrusevska Tozi ${ }^{2}$ \\ ${ }^{1}$ Pharmaceutical Chamber of Macedonia, 50-ta Divizija 34, 1000 Skopje, Macedonia \\ ${ }^{2}$ Faculty of Pharmacy, University "Ss Cyril and Methodius", Vodnjanska 17, 1000 Skopje, Macedonia
}

Received: September 2012; Accepted: November 2012

\begin{abstract}
From a historical point of view, one can notice that the role of the pharmacists employed in community and hospital pharmacies became more complex. Today, they do not only supply, store, prepare and dispense medicines with ensured quality, but they also provide professional services based on the concept of pharmaceutical care and good pharmacy practice.

In this paper, detailed review on the current legislative regulating the status and practice of the community and hospital pharmacies in some EU-member countries and in Macedonia is given. The implementation of the concept of pharmaceutical care and good pharmacy practice in selected EU member-countries, Great Britain, Germany and Slovenia, and in Croatia as a future EU member as well as in Macedonia is also discussed. In addition, set of recommendations for establishing the good pharmacy practice standards is prepared and presented. At the end, an attempt is made to establish a basis for development a modern Law on Pharmacy Practice in the Republic of Macedonia.
\end{abstract}

Keywords: good pharmacy practice, standards, legislation, EU, Macedonia

\section{Introduction}

The pharmacy profession comprises a broad area of academic and professional disciplines founded in science, business, sociology and law. During the past few decades, pharmacy, as other professions, has been changing rapidly. Until recently, the pharmacists were strictly responsible for the pharmaceutical product, production and quality control, supply, storage and dispensing to the patients at a recommendation from physicians. However, as the pharmacy industry grew and expanded, the most frequently prescribed medicines became commercially available. This situation, as well as the knowledge the pharmacists have about medicines and medicinal forms, the ways of their administration, the mechanisms in which they act and many other pharmacotherapy specific considerations

\footnotetext{
*jasminka@fk.mk
}

have allowed pharmacists to direct their attention to the patients, thus becoming an important health care provider (Pisano, 2003). One can safely say that the role of the pharmacists has shifted from preparation to dispensing of medicines, and most recently to providing professional services, a direction adopted though the concept of pharmaceutical care and clinical pharmacy (Van Mil and Schulz, 2006). The term pharmaceutical care has been firstly published in 1975. Hepler and Strand (1990) have brought this term back to life with their definition suggesting that pharmaceutical care means responsible provision of medicines in order to achieve specific outcomes that will improve the patient's quality of life. As a consequence, in the 1990s the key pharmacist organizations began to view pharmaceutical care as the pillar of their profession.

In the next few years, the concepts of pharmaceutical care and good pharmacy practice (GPP) were defined and the foundations for the application of those concepts were established. The evidence of these activities is several key 
documents, including those of the World Health Organization (WHO) and the International Pharmaceutical Federation (FIP). These documents, such as FIP: Good Pharmacy Practice in developing countries; Recommendations for step-wise approach, 1993, FIP: Standards for Quality of Pharmacy Services (in developed countries), 1993 and FIP/WHO, Annex 8: Joint FIP/WHO guidelines on good pharmacy practice: standards for quality of pharmacy services from the WHO technical report series, 2011 represented and still represent the basis for establishment and development of GPP on national level, both in developed and developing countries.

The European Union (EU) was created in 1958 by six countries in order to establish a common European market. It further expanded and since 2007 it has 27 member states and a population of half a billion people. In 2013, the number of member states will increase to 28, since Croatia will join the unified European family. The basic principles of the Union are to support free movement of goods, services, capital and citizens (Treaty establishing the European Community 2002).

The main medicines suppliers of the patients/consumers in the EU are the community pharmacies. Thus far there are not any harmonized policies covering the services of community pharmacies. There are about 400,000 community pharmacies in Europe (Pharmaceutical Group of EU - PGEU, 2011). The medicines distribution is also controlled in accordance with the supranational as well as national laws (Taylor et al., 2004). In most of the EU member countries, the community pharmacy specific laws are controlled by the governments. The EU community pharmacies are traditionally small, privately owned enterprises, operating under strict control by the state. Although there are many similarities between the laws of the different member states regarding both community and hospital pharmacy practice, the specific national laws regulating pharmacy practices and services still differ from each other greatly with respect to the health systems in the different countries.

\section{Objectives}

Having in mind, on one hand the differences in the legal status of the pharmacy practice and services in the different EU member and non-member countries, and the absence of defined GPP standards as well as a Law on Pharmacy Practice in the Republic of Macedonia on the other hand, in writing this paper, the following objectives were established: (i) to review the current legal status of the pharmacy practice in certain EU member and candidate countries; (ii) to review the national legislation regulating the pharmacy practice; (iii) to prepare a sets of recommendations for establishing GPP; and (iv) to establish a basis for preparation of a modern national Law on Pharmacy Practice.
With respect to the first objective, the review on the legal status of the pharmacy practice includes the relevant legislation of EU member countries with long traditions in pharmacy practice, high GPP standards and level and scope of clinical and pharmacy services, such as Great Britain and Germany, then a current member country, Slovenia, and a future member country, Croatia, with a level of pharmacy practice and services closest to ours, having in mind the entire and, at times, common socioeconomic development. The review on the domestic legislation includes existing laws, rule books and guidelines that regulate the pharmacy practice, which together with the existing legislation in the $\mathrm{EU}$ member countries can serve as a basis for enactment of a set of recommendations for establishing GPP standards and preparation of a modern Law on Pharmacy Practice.

\section{Legal status of the pharmacy practice in Great Britain}

The work of pharmacies in Great Britain is subject to numerous laws and other legal acts. One of the first laws that regulated the profession is the Pharmacy Act (1852), which established a system for control of the pharmacy practices by asking professionals for a registration as a chemist, druggist and/or pharmaceutical chemist. This was followed by the Pharmacy and Poisons Act (1933), which already required pharmacists to associate in a professional association, followed by the Pharmacy Act (1954), which referred only to individual pharmacists. The Health Services and Public Health Act (1968) regulates the spatial and staffing requirements for the pharmacies. The pharmacy staff in Great Britain comprises: pharmacists, pharmaceutical technical assistants, dispensary assistants and medicines counter assistants.

The Health Services and Public Health Act (1968) and Prescription Only Medicines Order (1997) are the two main legislations that cover the production, sale and use of medicines. These also cover the prescription of medicines. There are three main classes of medicines: (a) prescription only medicines - POMs which can only be procured with a prescription issued by an appropriate prescriber (for example: physician, dentist, pharmacist and in specific occasions nurse prescribers or additional prescribers); (b) pharmacy medicines - these are medicines that can be issued only in a registered pharmacy or under the supervision of a pharmacist; (c) medicines from the general sale list that can be sold in a wider variety of places without supervision of the pharmacist (for example: supermarkets).

The current Law also specifies who can and who cannot prescribe medicines. In addition, the Law allows for agreements to provide medicines to specific groups of patients under certain conditions. There are two different types of prescribers: (i) an independent prescriber is a prescriber that can prescribe medicines on his/her own from 
the British National Formulary (examples for independent prescribers include: physicians, independent nurse prescribers and independent pharmacist prescribers) and (ii) the supplementary prescriber can prescribe medicines in accordance with the clinical management plan (this plan is negotiated by the supplementary prescriber, the physician and the patient). Just as it allows pharmacists to prescribe medicines, the Law also allows physicians to dispense medicines, under regulated conditions specified in the relevant bylaws.

The National Service Act from 1977 (still in force), together with the amendments to the Health and Social Care Act (2001) provide to the health authorities in Great Britain a legal basis to organize and provide pharmacy services to patients. Thus, Article 41 of the 1977 Act is entitled: "Arrangements for pharmacy services". The services are subject to a contract whose details are negotiated by the Pharmaceutical Services Negotiating Committee - PSNC, the Department of Health - DoH and the staff from the National Health System. PSNC promotes and supports the interests of the community pharmacies that are part of the National Health System. They are recognized by the State Health Secretary as a body that represents all contractors pharmacies.

The contract (frame) of the pharmacies from the National Health System comprises three levels: (a) essential services; (b) advanced services; and (c) enhanced services. The pharmacy owners (contractors, the contract signatories for the pharmacies) have to provide the essential services, but, have also an option to provide advanced or additional services. The essential services are: dispensing, repeat dispensing, waste management, promotion of healthy lifestyle, referring patients to other health care provider, support of self-care and clinical management. The advanced services include: management of the medication use review and prescription intervention services, new medication services, appliance use review services and stoma appliance customization services. The enhanced services are a group of services provided locally upon an order from the Primary Healthcare Funds. A group of specific services of this sort were provided in England, including: small disease management, palliative care services, provision of home care, lice management services, gluten free food supply service, school services, services related to supplementary and independent pharmacist prescribing. Most of the services in this group are guided by public health aims, such as: substance abuse services, sexual health services, services related to smoking cessation, flu protection services, etc.

Hospital pharmacies are mainly regulated by three laws: (i) the Health Services and Public Health Act, which regulates the production, distribution, export, import, sales and supply of medical products, (ii) the Medicine Abuse Regulations; and (iii) the Pharmacy Act. The Health Services and Public Health Act (1968) specify that certain activities are legal when done in a hospital or by the hospi- tal staff. The following activities may be done by or under supervision of a pharmacist in a hospital: (i) preparation of medicine in accordance with a prescription given by a practitioner; (ii) dispensing of medicine in accordance with a prescription given by a practitioner; (iii) assembling a medicine; and (iv) preparing a stock of medicines with a review to dispense them in accordance with a prescription given by a practitioner.

About 6,000 pharmacists work in hospitals in Great Britain. Most of them work in hospitals that are a part of the National Health System, but some work in the private sector. Data on the operation of hospital pharmacies and hospital pharmacists are included in the reports of the European Association of Hospital Pharmacies. They state that the pharmacists that work in hospital pharmacies in Great Britain shall be required to have the same education profile as the pharmacists that work in community pharmacies. However, most of the hospital pharmacists acquire an even higher level of education, for example the pharmacists finish graduate studies in clinical pharmacy or specialize in hospital pharmacy. The Health Services and Public Health Act do not require the hospitals to have a registered pharmacy nor to employ a pharmacist. However, the policy of the National Health System is such that it requires the pharmacist to provide safe and efficient medicine management system in the entire hospital, although not obligatory responsible for the supply of medicines. According, to the same source, European Association of Hospital Pharmacies, more and more pharmacists spend their time on hospital wards, including time spent on rounds, monitoring what has been prescribed and advising the nurses and the physicians on the safe use of medicines. The hospital pharmacies in Great Britain have developed their clinical activities with a view of providing patient with the maximum benefit from the treatment at least possible costs.

\section{Legal status of the pharmacy practice in Germany}

In Germany there are several legal acts that regulate the profession, pharmacies and medicines: The Medicinal Products Act (Gerzets über Medizinprodukte, Federal Law Gazette from 12.12.2005, as amended on 28.9.2009), the German Pharmacies Act (Gezets über das Apotenkenwesen, Federal Law Gazette from 15.10.1980, as amended on 28.5.2008) and the Ordinance on the Operation of Pharmacies (Apotekenbetriebbsordnung - ApBetrO, Federal Law Gazette from 9.2.1987, as amended on 2.12. 2008).

The Medicinal Products Act (2005) regulates the medicines and their marketing. What this Law prescribes regarding the requirements for medicines, the production of medicines, the procedure for marketing authorization of medicines and other requirements is in accordance with the European legislation, especially the Directive 2001/83/ EC. The German Pharmacies Act regulates that "the phar- 
macies shall be responsible to provide appropriate medicinal products to the population as required by public interest and individuals intending to operate a pharmacy and up to three subsidiary pharmacies should require permission from the relevant authority" (Article 1).

The operations of hospital pharmacies, military pharmacies, pharmacy subsidiaries and the emergency pharmacies are regulated in the second chapter of the German Pharmacies Act. Upon application, the sponsoring institution for a hospital must be granted a permission to operate a hospital pharmacy if: (i) employs a pharmacist that fulfills the same requirements as for working in a community pharmacy and (ii) proves that the hospital pharmacy requirements prescribed in the Ordinance on the Operation of Pharmacies (Article 14, Item 1, Paragraph 1) have been fulfilled. The manager of the hospital pharmacy or the pharmacist commissioned by him/her must inform and consult the hospital's physicians on the medicines, especially with regard to the purposeful and economical medicinal treatment (Article 14, Item 1, Paragraph 2). The hospital pharmacy can acquire a license to supply another hospital by signing a written contract (Article 14, Item 3).

The third section of this Act regulates the Ordinance on Operation of Pharmacies $(1987 ; 2008)$. It is stated that the pharmacies in Germany can employ pharmaceutical and non-pharmaceutical staff on positions compatible with their education and knowledge. The pharmacy staff comprises: pharmacists, individuals in training to become a pharmacist, pharmaceutical-technical assistants, individuals in training to become a pharmaceutical-technical assistant, assistant pharmacists, pharmaceutical engineers, individuals in training to become a pharmaceutical engineers, pharmacy assistants and pharmaceutical assistants. Nonpharmaceutical staff includes in particular pharmacy aides, skilled pharmacy workers and pharmaceutical-commercial employees that, within the pharmaceutical activities, assist the pharmacy staff in preparation and testing of pharmaceuticals (Article 3).

Pharmaceutical activities in accordance with this Ordinance shall include development, preparation, testing and dispensing of pharmaceuticals, information and advice on pharmaceuticals as well as checking of pharmaceutical inventories (in hospitals) (Article 3, Paragraph 4). Persons that are not part of the pharmacy staff shall be forbidden from performing pharmacy activities (Article 3, Paragraph 5). The person performing pharmacy activities has to have an excellent command of the German language (Article 3, Paragraph 5). The type, size, number, location and equipment of the premises are regulated in Article 4 and they must be suitable for the operation of the pharmacy.

Germany allows the purchase and dispensing of the medicines prescribed by a veterinarian and this is regulated in Article 19.

The pharmacist must inform and advise customers and individuals entitled to practice medicine, dentistry or veterinary medicine as far as this is required for reasons of drug safety. The managing pharmacist of a hospital-supplying pharmacy or the pharmacist authorized by him/her must inform and advise the physicians of the hospital on pharmaceuticals. He/she is a member of the Hospital Drug Commission (Article 20, Paragraph 1). Article 21 regulates the management of the medicines risk and the risk of non-marketable medicines (for example: withdrawn medicines). Maintaining proper records is one of the most important things in the modern pharmacy operations and it is regulated in Article 22.

Articles 26 to 33 regulate the operations of hospital pharmacies, while Articles 34 to 37 specify the penalty provisions. Hospital pharmacies are a functional part of hospitals, responsible for proper supply of one or more hospitals with medicines (Article 26, Paragraph 1). The pharmacist responsible for maintaining the pharmacy should check the stored medicinal products (Article 32). The hospital pharmacies are required to provide for additional working hours (stand by duty) in order to ensure the proper supply of the hospital with medicines (Article 33).

The community pharmacies in Germany, in addition to medicinal products can also sell parts, information objects or media that directly or indirectly help or promote the health of people or animals, testing chemicals, chemicals, laboratory reagents, parts and objects for personal hygiene and body care, pesticides and plant protection agents and products used in the growing of animals.

\section{Legal status of the pharmacy practice in Slovenia}

The pharmacy practice in Slovenia is regulated in several laws and bylaws: the Law on Healthcare (Zakon o zdravstveni dejavnosti, Official Gazette of RS 23/2005 as currently amended), the Law on Pharmacy Practice (Zakon o lekarniški dejavnosti, Official Gazette of RS 36/2004 as currently amended), the Law on Health Insurance (Zakon o zdravstvenem varstvu in zdravstvenem zavarovanju, Official Gazette of RS 72/2006 as currently amended) and the Rule Book on Pharmacy Practice (Pravilnik o pogojih za opravljanje ljekarniške dejavnosti, Official Gazette of RS 36/2004).

The only reference to the pharmacy practice in the Law on Healthcare (36/2004) is made in Article 20 where it states that "the pharmacy activities shall be regulated by a separate law". Therefore, the pharmacy practice is comprehensively included in the Law on Pharmacy Practice (36/2004). Article 1 and 2 of this Law define the pharmacy practice as a part of the healthcare and public service performed by public institutions and the individual concessioners in the pharmacies and their subsidiaries, and that, in addition to supplying population with medicines, they also supply medical devices and veterinary medicines, prepare and control medicines and medical devices, provide advice on use of medicines at the moment of dispensing. Articles $5,6,7$ and 8 suggest that the pharmacies should fulfill spe- 
cific requirements with respect to premises, equipment and staff. These requirements are regulated in more detail in the Rule Book on pharmacy practice. The second part of this Law defines the public institute as an organization of pharmacies and their subsidiaries as its organizational units that perform pharmacy practice (Article 10), managed by a council (Article 11) that elects a director (Article 12) who manages the organization. The third part of the Law defines concessions as an opportunity to open a pharmacy and perform pharmacy practice. The fourth part of the Law refers to the subsidiaries of pharmacies that can work only under the supervision of the pharmacy to which they belong (Article 21). The fifth part refers to hospital pharmacies. This Law also addresses the working hours, supervision, association within a Pharmaceutical Chamber as well as penalty provisions for non-compliance with the provisions of this Law.

The Rule Book for pharmacy practice (36/2004) explains in more detail everything that is regulated in the Law on Pharmacy Practice (36/2004). Thus, Article 1 states that "this Rule Book shall determine the requirements that the staff, premises, equipment, reference literature, the record keeping and method for registration of a pharmacy must fulfill". Pharmacy activities take place in hospital pharmacies, as well as in their organizational parts (Article 1). The hospital pharmacy is an organizational unit of the hospital responsible for supplying the hospital with medicines and medicinal products for treatment and care of hospitalized persons (Article 2, Item 1). In addition, pharmaceutical care has been defined as a "responsible provision of therapy to achieve a positive final outcome with a view of optimizing the quality of life of the patient" (Article 2, Item 3). Article 3 of this Rule Book contains the services that can be provided by the pharmacy. There are total of 32 services in addition to preparation and dispensing of medicines and medical devices, preparation, control and dispensing of magistral products and homeopathic medicines. The pharmacy can also provide record keeping on medicines for future audit and inspection, advices and information with reference to medicines and medical devices and pharmaceutical care. The hospital pharmacists are allowed/ encouraged to participate in clinical trials and pharmacy and therapeutic committees.

The second part of the Rule Book contains the requirements that the pharmacies have to fulfill. First it describes the external, physical characteristics that a pharmacy should have, in particular that a pharmacy has to be appropriately marked, so they could be visible and distinct from other shops. With respect to the staff, it states that the pharmacy shall be managed by responsible pharmacist (Article 6). The rooms within the pharmacy must be distributed and equipped in a manner that will satisfy the quality requirements in accordance with the Good Pharmacy Practice (Article 8, Paragraph 1). The pharmacy must have, in its premises, written or electronically available reference literature as a source of information and advice on the med- icines and for the purposes of preparation of good quality products (Article 22). Within the scope of its work, the pharmacy must keep records (documentation) for medications.

A hospital pharmacy must have at least the following areas: (i) medicine reception, (ii) medicine dispensing area, (iii) medicine storage area, (iv) toolkit washing area, (v) administration area and (vi) toilets and wardrobe (Article 11). The total surface areas for a special hospital, general hospital and a clinic and institute, respectively, are specified in Article 11. A hospital ward pharmacy that organizes the preparation of particular pharmaceutical forms must also have an area: (i) for preparation and (ii) for washing the toolkits (Article 12, Paragraph 3).

\section{Legal status of the pharmacy practice in Croatia}

Pharmacists and the pharmacy practice in the Croatian legislation can be found in several laws and other legislative acts, but mainly in the Law on Healthcare (Zakon o zdravstvenoj zaštiti, 150/08 with all its amendments), the Law on Medicines (Zakon o ljekovima, 71/07 with all its amendments), the Law on Pharmacy (Zakon o ljekarništvu, 121/03 with all its amendments), the Law on Mandatory Health Insurance (Zakon o obaveznoma zdravstvenom osiguranju, 150/08 with all its amendments) and the Rule Book on the Conditions under which a Pharmacy can be Opened (26/07).

The Law on Healthcare (150/08), Article 26, Paragraph 1, which stipulates everything that is included under primary healthcare, also states "supply and preparation of medicines and supply of medicinal products (line 17)", and Paragraph 2, which stipulates the primary healthcare activities, also states "pharmacy practice (line 15)". This Law, section VII, under the title "Healthcare institution", Article 78 states that the healthcare institution, among other things, shall also perform pharmacy practice. In addition, Chapter VIII Secondary Healthcare Institutions, under the title Hospital, Article 88 states that "among other things, the organization shall also supply medicines and other medicinal products".

In the Law on Medicines (71/07), with reference to the pharmacy practice and regarding the dispensing of medicines and patient related services, only the Article 65 regulates the retailing of medicines and their marketing. However, the pharmacy practice and pharmacies are most comprehensively regulated in the Law on Pharmacy (121/03), which regulates the method of organizing and implementing pharmacy practice as a part of the healthcare system, performed as a public activity by pharmacists (Article 1). The second section of this Law addresses and regulates the pharmacy practice, supply and preparation of medicines as well as supply of the population, healthcare institutions, other legal entities and private practice healthcare workers with medicinal products (Article 1). However, Article 
5, Paragraph 1 states that "in addition to supply of medicines (Article 2) there is also supply of homeopathic products, food for children, dietary products, cosmetic and other health protecting agents and also advising on prescription or the proper administration of medicines, homeopathic and dietary products". The pharmacy activities are performed by masters of pharmacy in cooperation with other health workers. They implement pharmaceutical care in order to achieve a better outcome from the pharmacotherapy, to promote rational use of medicines and medicinal products and actively to participate in the prevention of diseases and health protection (Article 6, Paragraph 1). The pharmaceutical care in accordance with this Law includes rationalization of the treatment costs, promotion of the treatment procedures and objectives, monitoring, avoidance or reduction of adverse drug reactions, avoidance of interactions, double therapy or allergies, care for patients' compliance, improvement of the clinical treatment outcomes and implementation of preventive measures for health preservation and protection (Article 6). The third section of this Law regulates the establishment and organization of the pharmacy practice and states that the pharmacy activities shall be performed within an established network of healthcare in accordance with a special law (Article 7, Paragraph 1).This part also regulates that the activities have to be performed at a primary, secondary and tertiary level (Article 7, Paragraph 2). The activities would be performed in pharmacies and depots, and only partly in galenic laboratories for verifying the quality of the galenic preparations and identification of active substances (Article 8). Hospital pharmacies are regulated in Article 10 where it states that "the hospital pharmacy shall ensure the supply of hospital healthcare institutions with medicines and medicinal products necessary for the hospital activities". The galenic laboratory is regulated in Article 11, while the laboratory for controlling the quality of the galenic preparations and identification of active substances is in article 12 . In section seven, this Law also regulates another important operational segment and that is documentation. Expert supervision over the work of the pharmacies, the laboratories, and the masters of pharmacy will be performed by the Chamber (Section 8).

Another legal act important for the regulation of pharmacy operations in Croatia is the Rule Book on the Requirements for the area where a pharmacy can be opened $(26 / 07)$. The conditions that determine the area are the number of persons with mandatory health insurance and the distance between pharmacies (Article 2).

\section{Legal status of the pharmacy practice in the Republic of Macedonia}

The pharmacies and the pharmacy practice in Macedonia are regulated in several laws and bylaws. One of them is the Law on Health Protection (Закон за здравствената заштита, 43/2012 from 29.03.2012). This Law is relatively new and substantively differs from the previous Law (1997), in particular with reference to the establishment of the healthcare system and the provision of healthcare services. The Law is currently being implemented and the bylaws are being enacted. The Law offers to some extent a slight improvement over the previous one. It defines pharmacy activities, which are broader, and addresses the entire field of operation of the pharmacists as it is required by the GPP guidelines. It has a new and expanded definition of a pharmacy as a healthcare institution.

Another Law that regulates the pharmacy activities is the Law on Medicines and Medical Devices (Закон за лековите и медицинските помагала, 106/2007, 88/2010, $36 / 2011,53 / 2011,136 / 2011)$. It regulates the medicines and medical devices that are used in human medicine, the conditions and the method of assuring their quality, safety and efficiency, the method and procedure of production, testing, marketing, formation of prices, quality control, inspection and supervision, which is largely in accordance with the European regulations i.e. the Directive for Medical Products for Human Use (2001/83/EC). According to the Article 13 of this Law, medicines can be classified according to the place and manner of dispensing as: (i) medicines dispensed only with a prescription; (ii) medicines dispensed without a prescription; and (iii) medicines dispensed only in a healthcare institution. Medicines dispensed without prescription are medicines with a broad spectrum of therapeutic indications, low toxicity, low possibility of overdosing, insignificant interactions, well known indications for the patients and appropriate for selftreatment (Article 12, paragraph 2). The third section of this Law regulates the marketing of medicines. Article 81 stipulates that "the medicines will be retailed in pharmacies" (Paragraph 1), that "the retailing shall mean supply, storage, keeping and dispensing of medicines" (Paragraph 2) and that "a pharmacy shall be a legal entity that shall be established and operate in accordance with this Law (Paragraph 3) and the Law on Health Protection" (previously stated). The Law on Medicines and the Law on Health Protection requires the pharmacies to fulfill appropriate conditions: have appropriate premises, equipment and staff, have an appropriate number of employees with higher education in the area of pharmacy and with secondary education in the area of pharmacy. The Law on Medicines further regulates that "the pharmacy shall keep appropriate records of the consumption of medicines, introduce a system of quality and an organized work flow in accordance with the principles of good pharmacy practice and fulfill the obligations of a public service i.e. the obligation to guarantee continuous and appropriate variety and quantity of medicines in order to meet the needs of the patients in a specific geographic area" (Article 82). Article 82, the last paragraph also stipulates that "the Minister of Health shall enact a manual on the principles of good pharmacy practices". 
Pursuant to this Law (Article 13, Paragraph 4), the Rule Book on the method of dispensation of prescription medicines (106/07) was enacted. This Rule Book regulates the method of prescribing and dispensing of the medicines. It is strictly forbidden to dispense prescription medicines without a prescription, a provision which is not completely enforced in the Republic of Macedonia.

Another Law that has provisions that regulate pharmacy activities is the Law on Health Insurance (Закон за здравственото осигурување, 25/2000 with all its amendments), which regulates the health insurance of citizens, the rights and obligations arising from the health insurance as well as the way of implementing health insurance (Article 1). According to this Law, the list of basic services covered by the Health Insurance Fund also contains medicines in accordance with the list of medicines which is determine by a general Act enacted by the Health Insurance Fund, agreed by the Minister of Health (Article 9, Item 8) and approved by the Commission from the Government of the Republic of Macedonia (Article 9-a, Paragraph 2). The Health Insurance Fund is the only one state owned purchaser of health services on behalf of the insured persons (Article 68 - a, Paragraph 1) and, depending on the need for healthcare services and the allocated funds for that purpose in the budget of the Fund, it signs or terminates contracts with healthcare institutions i.e. pharmacies (Article 68-a, Paragraph 2). Currently, the Fund pays to the pharmacies only for the service of supplying and dispensing of medicines. Pursuant to several different articles in the Law on Health Insurance, the management board of the Health Insurance Fund of Macedonia enacted a Rule Book (2000) on the content and method of administering the rights and obligations arising from the mandatory health insurance. This Rule Book also regulates the use of medicines (Section 8). The form for dispensing medicines covered by the Fund is different from the form for medicines regulated by the Rule Book on the method of dispensing of prescription medicines (106/07) enacted in accordance with the Law on Medicines and Medical Devices (106/2007).

The Government of the Republic of Macedonia, in accordance with the Law on Health Protection enacts health programs like the Health for All Program (2011) where pharmacists are not directly involved. There is no legislatively mandated or contractual obligation for the pharmacists to be included in such programs with their services.

\section{Recommendations for establishing GPP standards in the Republic of Macedonia}

Considering the pharmacy legislation, pharmacy activities, services provided by the pharmacists and the role of the pharmacists in the health protection and prevention from diseases, establishing a concept of GPP according to the latest joint FIP/WHO Guidelines for GPP: Standards for quality of pharmacy services (2011) would be of great importance. This Guideline states that "when establishing minimum GPP standards, it is important first to define the roles of the pharmacists, as expected by the patients and society. Secondly, relevant functions for which pharmacists have direct responsibility and accountability need to be determined within each role. Thirdly, minimum national standards should then be established in a set of activities supporting each role in order to satisfy the needs of the people and society. As the Guideline state, the minimum national standards for each activity are based on processes that need to be relevant and defined appropriately according to the local needs for pharmacy practice and national profession aspirations. It would be good to review the roles of the pharmacists and accordingly, the activities and needs, the minimal national standards setup in the Guideline, our national legislation and environment in which the pharmacists work and to discuss what would be recommendable to change and amend.

According to the Guideline, the first role of the pharmacists is to prepare, obtain, store, secure, distribute, administer, dispense and dispose medicinal products. This role entails the preparation of extemporaneous medicinal preparations and products for which the minimum required standards are related to requirements regarding premises and providing consistent preparations in accordance with prescription standards and formulas, quality standards for raw materials, equipment and preparation processes. These requirements have been regulated in the current regulative in the Republic of Macedonia. Another function of pharmacist is to obtain, store and secure medicinal preparations and products. This function is also regulated in Macedonia. However, it needs to be augmented with several provisions that will ensure quality of supply from the point of view of transparency and avoidance of entry of substandard, low quality, unapproved, fake or falsified medicines. The EU has enacted a Directive 2011/62/EU that regulates this issue. Currently, the Directive is being implemented in the national legislations of the EU member states. In addition, provisions should be enacted that will regulate the information system that will support the roles, functions and activities of the pharmacists. Great Britain, Germany, Slovenia and Croatia have such systems, whereas in Macedonia it is still in the pilot stage. The third function is distribution of medicinal preparations and products. Minimum national standards should be established for these activities. The minimum national standards in this respect have been implemented in Macedonia, especially in the Law on Medicines and Medical Devices. The only thing that could be strengthened concerns the establishment of an efficient system for recalling of medicines that are known or suspected to be unapproved, fake or falsified and to prepare a strategy for disaster or pandemic preparedness.

The fourth function is the administration of medicines, vaccines and other injectable medications. This function requires appropriate education and training of the pharmacists, suitable premises and procedures. This function is 
regulated and implemented only in several European countries, such as Portugal. Nevertheless, the other countries undertake activities to regulate and implement this function. It is recommendable to introduce and functionally implement this function in Macedonia as well. The fifth function is dispensing of medicinal products. The dispensing of medicines is regulated in Macedonia, but it requires some amendments. It is necessary to enact procedures for this function and to provide discretion in the space where medicines are dispensed and advice is given at the time of dispensing, having in mind, the provisions stipulated in the Law on personal data. The sixth function is disposition of medicines. With respect to what could be done in Macedonia, some amendments regarding this issue should be provided such as the procedures that should be enacted for the previous function.

The second role that the pharmacists must have is to provide efficient therapy management. According to the Guideline, the first function of this role is the assessment of the health status and the needs of the patient. This role has been recognized in Great Britain. In Germany, Croatia and Slovenia, it is present in the secondary legislation arising from their national pharmacy laws/acts. In Macedonia this is not regulated by law or by any other regulation. If a Law on Pharmacy Practice is drafted and enacted, it would be good if this function is defined there or in the secondary legislation arising from the Law.

The second function of this role is management of patient medication therapy. This function entails access to an appropriate evidence base related to the safe, rational and cost-effective use of medicines such as reference books and scientific literature, then having a key role in educating prescribers on the access to and evidence for optimal and appropriate use of medicines, use of clinical data and patient data for therapy adjustment, as well as enactment of procedures for referral of the patients to other health workers and provision of healthcare continuity. The legislation in the countries reviewed by this paper regulates this function, while in Macedonia this function is not regulated. However, it could be regulated if a Law on Pharmacy Practice is enacted. The third function is monitoring of patient progress and outcomes. This function, in addition to requiring patient dedication, also requires record keeping. In Germany, Slovenia and Croatia this function is regulated in their primary and secondary legislation on pharmacy practice, and in Great Britain it is regulated in the contracts signed by the pharmacies. This function should be regulated in Macedonia as well. The fourth function is provision of information on medicines and health-related issues. This function exists in the legislations of each of the mentioned countries, as part of the definition of pharmacy practice. In Macedonia, this function should be included in the law(s), rule book(s) and regulation(s).

The third role that the pharmacists have to have is maintenance and improvement of professional performance through the function for planning and implementa- tion of strategies for continuous professional development. This role has been recognized and much effort for implementation is done in Macedonia.

The fourth role is contributing to the improvement of the efficiency of the healthcare system and public health through the functions of dissemination of evaluated information on medicines and various aspects of self-care, engagement in preventive care activities and services, compliance with national professional obligations, guidelines and legislations and advocating and supporting national policies that promote improved health outcomes. The information aspect has not been addressed or regulated in Macedonia, unlike the other countries mentioned here, where the information aspect is one of the most recognized and first defined function of the pharmacists. As was previously stated, the pharmacists are not mentioned in the prevention activities that promote public health and disease prevention. Certainly, with respect to this function and the function of advocating and supporting national policies, the pharmacists in Macedonia have to be more active and demanding through their associations or on their own.

\section{Basis for drafting a modern national Law on Pharmacy Practice}

One important document for the healthcare sector in the Republic of Macedonia is "Health Strategy of the Republic of Macedonia 2020, a safe, efficient and fair health system" (2007). This document provides a snapshot of the healthcare system at the time together with the demographic and social aspects and needs of the population and the country. It also gives recommendations on what should be done to promote the healthcare system, to raise the level and scope of the services (including pharmacy) and, at the same time, to rationalize the functionality and reduce costs. The enactment of this document is of a great importance to the entire health system and in particular to the pharmacy sector. The weaknesses in pharmacy practice were identified and recommendations given as to what to do in the future. Part of these recommendations brought positive results such as: review of the positive list, the list of medicines covered by the Health Insurance Fund, which should be reviewed more frequently in order to provide better medicines and to increase availability of the medicines to specific categories of patients. Very important, the concept of "pharmaceutical care" was mentioned for the first time and it was stated that a transformation of operations is required, which would entail enactment of appropriate guidelines for GPP that will contain the national standards as well. It also states that models need to be developed for providing pharmaceutical care at all levels of healthcare, including the recognition of the roles of pharmacists in accordance with the GPP standards.

The Green Book (2009), need to establish GPP standards in accordance with the latest FIP/WHO Guideline, 
the needs for transformation imposed globally and the national needs are a good basis for enacting a Law on Pharmacy or Pharmacy Practice in the Republic of Macedonia. There are numerous reasons for enacting such a Law. One of them is certainly Macedonia's aspiration to enter the European Union and the trend in the EU regarding approximation of the national regulative framework. Another incentive to pass such a Law is the existence of such laws in the EU countries and not only in the countries with long traditions and high GPP standards such as Great Britain and Germany. Looking at the Laws and the Rule Books arising from it in Slovenia and Croatia, one can notice that the legislation contains most of the required provisions for pharmacy practice, services, spatial and staffing requirements, based on the concept of pharmaceutical care and GPP and the national socioeconomic needs to establish and maintain a modern health system focused primarily on the health of the population. Certainly, in addition to the experiences of the other countries, the drafting of a legislation of this kind would also require a broader examination of the current situation in the pharmacy sector in Macedonia. This will help to identify the weaknesses in order to overcome them and will also help to guide the process of drafting and enacting the legislation.

The benefits from having a Law on Pharmacy (Practice) are numerous. This will benefit the pharmacists, because they will be more recognizable, more involved, they will use their knowledge and skills better, and they will be more engrossed in the provision of health to the population. Society will get better quality, economically more favorable services, the health system will be more efficient, better and the savings will be greater, primarily due to better prevention. The biggest benefit will be that of the population, in particular the patients. They will get a better, more efficient and more acceptable system of services.

\section{Conclusion}

The review on the regulations regarding pharmacy practice and services in Great Britain, Germany, Slovenia and Croatia suggests that there are differences in the regulation of the individual segments of the pharmacy practice. For example, there are small differences in the requirements for opening new pharmacies. There are differences in the definition of the roles of the staff in the pharmacies which, primarily, do not refer to the pharmacists with higher education and working license. The regulations for them have been harmonized, primarily because of the European regulations. It is also important that the roles defined in the national regulations of these countries are in accordance with the roles stipulated in the Joint Guidelines of WHO and FIP (2011). The requirements for the pharmacist competences are mostly similar and in accordance with the GPP requirements. With respect to the requirements related to the premises, equipment and distribution in the phar- macies located in inhabited areas, there are differences in the regulations of these countries because of the differences in the priorities of the national health policies, as well as the demographic, cultural, social and economic characteristics. With respect to the services provided by the pharmacies (community and hospital), one can say that there are differences, e.g. the number of services provided in Great Britain is the biggest. Also, the pharmacies get refunded for most of these services, either from the various funds or other health insurance companies. In Slovenia and Croatia, this number is smaller, but the current regulation provides a solid basis for this number to increase. In general, the pharmaceutical profession has been comprehensively addressed and regulated in all four countries, in accordance with the requirements for minimum national requirements stated in the Joint Guidelines of WHO and FIP (2011).

With respect to the legal status of the pharmacy practice and services in the Republic of Macedonia, it is necessary to change and augment the current legislation. Primarily because of Macedonia's aspirations to enter the EU, it needs to improve the provision of healthcare by introducing new, more efficient and more accessible patient services that will contribute towards savings in the health sector. The Macedonian legislation needs to be harmonized with the European legislation and a series of Directives need to be adopted such as the Directive on Falsified Medicines (2011/62/EU), the Directive on Electronic Trading (2000/31/EC), the Directive on Application of the Rights of Patients to Cross-Border Healthcare (2011/24/EC), etc. It is necessary to enact legislative solutions that will regulate the pharmacy practice in a way that will fulfill the minimal regulation requirements, in accordance with the Joint Guidelines of WHO and FIP (2011) and the national needs of the health system and the population, with a view of providing better, more efficient, more accessible and economically more favorable healthcare.

\section{References}

Directive 2001/83/EC of the European Parliament and of the Council of 6 November 2001 on the Community code relating to medicinal products for human use. OJ L 311, 28.11.2001.

EAHP/HOPE, Hospital Pharmacies in European Union, April 2002.

FIP, Good Pharmacy Practice in developing countries; Recommendations for step-wise approach, Sept. 5, 1993, Council Meeting, Tokyo.

FIP, Standards for Quality of Pharmacy Services (in developed countries), Good Pharmacy Practice, Sept. 5, 1993, Council Meeting, Tokyo.

FIP/WHO, Annex 8: Joint FIP/WHO guidelines on good pharmacy practice: standards for quality of pharmacy services from the WHO technical report series, No. 961, 45th report of the WHO Expert Committee on specifications for pharmaceutical preparations (C) World Health Organization 2011.

German Pharmacies Act, (Gezets über das Apotenkenwesen), Federal Law Gazette 15.10.1980, as amended on 
28.09.2009.

Guillaume L, Cooper R, Avery A, Mitchell S, Ward P, Anderson C, Bissell P, Hutchinson A, James V, Lymn J, McIntosh A, Murphy E, Ratcliffe J. Supplementary prescribing by community and primary care pharmacists: an analysis of PACT data, 2004-2006. J Clin Pharm Ther 2008; 33 (1): 11-6.

Health and Social Care Act 2001, Available at: http://www. legislation.gov.uk

Health Services Act 1977, Available at: http://www.legislation. gov.uk

Health Services and Public Health Act, 1968, Available at: http:// www.legislation.gov.uk

Health Strategy of the Republic of Macedonia 2020, efficient and fair health system, (Здравствена стратегија на Република Македонија 2020, сигурен, ефикасен и правичен здравствен систем), February 2007.

Hepler CD, Strand L. 1990, Opportunities and responsibilities in pharmaceutical care. Am J Hosp Pharm; 47:533-543.

http://www.nhs.uk/NHSEngland/AboutNHSservices/ pharmacists/Pages/pharmacistsandchemists.aspx

Law on Health Insurance, (Закон за здравственото осигурување) Official Gazette of RM 25/2000 (currently amended).

Law on Health Insurance, (Zakon o zdravstvenem varstvu in zdravstvenem zavarovanju), Official Gazette of RS 76/06.

Law on Health Protection,(Zakon o zdravstveni dejavnosti,), Official Gazette of RM 43/2012.

Law on Healthcare, (Zakon o zdravstvenoj zaštiti), Official Gazette of RC 150/08, 155/09, 71/10.

Law on Healthcare, (Zakon o zdravstveni dejavnosti), Official Gazette of RS 36/04.

Law on Mandatory Health Insurance,( Zakon o obaveznoma zdravstvenom osiguranju), Official Gazette of RC 150/08.

Law on medicinal products and medical devices, (Закон за лековите и медицинските помагала), Official Gazette of RM 106/2007, 88/2010, 36/2011, 53/2011, 136/2011, $11 / 2012$.

Law on Medicines, (Zakon o ljekovima), Official Gazette of RC 45/09, 71/07.

Law on Pharmacy Practice, (Zakon o ljekarništvu), Official Gazette of RC 121/03, 117/08, 35/08

Law on Pharmacy Practice, (Zakon o lekarniški dejavnosti), Official Gazette of RS 36/04.

Medicines Act 1968, Available at: http://www.legislation.gov.uk

National Health Service Act 1977, Available at: http://www. legislation.gov.uk
Ordinance on the Operation of Pharmacies, (Apotekenbetriebbsordnung - ApBetrO),Federal Law Gazette from 15.10.1980, as amended on 28. 5. 2008.

PGEU, European Community Pharmacy Facts \& Figures, PGEU DATA BASE for 2010 and 2011 May 2012, available at: www.pgeu.eu.

Pharmacy Act 1852, Available at: http://www.legislation.gov.uk

Pharmacy Act 1954, Available at: http://www.legislation.gov.uk

Pharmacy and Poisons Act (1933), Available at: http://www. legislation.gov.uk

Pisano DJ, Essentials of Pharmacy law, CRC Press, Pharmacy education services, United States, 2003.

Prescription Only Medicine Order, 1997, Available at: http:// www.legislation.gov.uk

Rule Book on Performing the Pharmacy Practice, (Pravilnik o pogojih za opravljanje ljekarniške dejavnosti), Official Gazette of RS 36/2004.

Rule Book on the method of dispensation of prescription medicines, (Правилник за начинот на издавање на лекови на рецепт), Official Gazette of RM 106/07.

Rule Book on the content and the method of administering the rights and obligations arising from the mandatory health insurance, (Правилник за содржината и начинот на остварување на правата и обврските за задолжителното здравствено осигурување), Official Gazette of RM 111/2000, 105/2011.

Taylor, D., Mrazek, M., Mossialos, E., 2004. Regulating pharmaceutical distribution and retail pharmacy in Europe. in: Mossialos, E., Mrazek, M., Walley, T., Regulating pharmaceuticals in Europe: striving for efficiency, equity and quality. Open University Press, Maidenhead, Berkshire.

The Pharmacy Contract, PSNC, 2011, 2012 available at http:// www.psnc.org.uk/pages/introduction.html

Tonna, A.P., Stewart, D., West, B., McCaig, D., 2007. Pharmacist prescribing in the UK - a literature review of current practice and research. J. Clin. Pharm. Ther. 32, 545-556.

Treaty establishing the European Community (Consolidated text). OJ C 325/33, 24.12.2002.

Treaty of European Union. OJ C 191, 29.7.1992 (consolidated text OJ C 325, 24.12.2002).

Väänänen, M., 2008. Community pharmacies and the needs of mobile EU citizens - a study of Fins living in Spain, Doctorial dissertation, pp 13-29.

Van Mil, J.W., Schulz, M., 2006. A review of Pharmaceutical care in Community Pharmacy in Europe. Harvard Health Policy Review 7(1), 155-168. 


\title{
Резиме
}

\section{Правната положба на аптекарската дејност во Европската Унија и Република Македонија}

\author{
J. Патчева ${ }^{1 *}$, К. Младеновска², Л. Петрушевска - Този² \\ ${ }^{I}$ Фармацевтска Комора на Македонија, 50-та Дивизија 34, 1000 Скопје, Македонија \\ ${ }^{2}$ Фармацевтски Факултет, Универзитет „Св. Кирил и Методиј“, Водњанска 17, 1000 Скопје, Македонија
}

Клучни зборови: добра фармацевтска практика, стандарди, законодавство, ЕУ, Македонија

Историски гледано, може да се забележи дека улогата на фармацевтите кои работат во јавните и болничките аптеки стана покомплексна. Тие, денес не само што набавуваат, чуваат, подготвуваат и издаваат лекови со обезбеден квалитет, туку и обезбедуваат професионални услуги базирани на концептот на фармацевтска грижа и добра фармацевтска практика.

Во овој труд даден е преглед на актуелните правни акти кои го регулираат статусот и дејноста на јавните и болничките аптеки во некои земји членки на ЕУ и во Македонија. Исто така се зборува и за имплементацијата на концептот на фармацевтска грижа и добра фармацевтска практика во одредени земји како Велика Британија, Германија и Словенија, Хрватска, како идна земја членка на ЕУ, и Македонија. Во продолжение, презентиран е низ на препораки за воспоставување на стандарди за Добра фармацевтска практика. На крај, направен е обид да се воспостават основи за изработка на современ Закон за аптекарска дејност во Република Македонија. 



\section{INSTRUCTIONS FOR AUTHORS}

Macedonian Pharmaceutical Bulletin is an official publication $\mathrm{f}$ the Macedonian Pharmaceutical Association. The journal publishes original scientific papers, short communications, reviews, mini-reviews and professional papers from all fields of pharmacy and corresponding scientific fields of interest for pharmacy (pharmaceutical and medicinal chemistry, immunology and imunochemistry, molecular biology, pharmaceutical analyses, drug quality control, pharmaceutical technology, pharmacoinformatics, pharmacoeconomics, biopharmacy, pharmacology, applied botany, pharmacognosy, toxicology, clinical pharmacy, food and nutrition, physical pharmacy, organical synthesis, social pharmacy, history of pharmacy etc.)

The Macedonian Pharmaceutical Bulletin, also, publishes and other contributions (recommendations and announcements, reports of meetings, important events and dates, book reviews, various rubrics).

\section{Types of paper}

Original scientific papers (full length manuscripts) should contain own unpublished results of completed original scientific research.

Short communications also should contain completed but briefly presented results of original scientific research. The article should be prepared as described for full length manuscripts, except for the following: the number of pages should not exceed 10 (including 2 illustrations, figures or tables). An Abstract should be included as well as a full reference list.

Reviews and mini-reviews are written at the invitation of the Editorial Board. "Mini-reviews" of a topic are especially welcome.

They should be surveys of the investigations and knowledge of several authors in a given research area, the competency of the authors of the reviews being assured by their own published results.

Professional papers report on useful practical results which are not original but help the results of the original scientific research to be adopted into practical use. Professional papers might be based on the elaborating of theoretical data

\section{Language}

Original scientific papers, short communications, reviews and mini-reviews should be written in good English (American or British usage is accepted, but not a mixture of these), while professional papers and all other contributions may be submitted in Macedonian.

\section{Submission declaration}

Submission of an article implies that the work described has not been published previously (except in the form of an abstract or as part of a published lecture or academic thesis), that it is not under consideration for publication elsewhere, that its publication is approved by all authors and tacitly or explicitly by the responsible authorities where the work was carried out, and that, if accepted, it will not be published elsewhere in the same form, in English or in any other language.

\section{Policy and ethics}

The work described in your article must have been carried out in accordance with The Code of Ethics of the World Medical Association (Declaration of Helsinki) for experiments involving humans http://www.wma.net/ en/30publications/10policies/b3/index.html;

EC Directive 86/609/EEC for animal experiments http:/ec.europa.eu/environment/chemicals/lab animals/ legislation en.htm;

Uniform Requirements for manuscripts submitted to Biomedical journals http://www.icmje.org. This must be stated at an appropriate point in the article.

\section{Submission}

Please submit the manuscript electronically (e-mail address: magl@ff.ukim.edu.mk) as a single PDF file, which will be used in the peer-review process. All correspondence, including notification of the Editor's decision and requests for revision, takes place by e-mail removing the need for a paper trail. 


\section{Referees}

Please submit, with the manuscript, the names, addresses and e-mail addresses of 3 potential referees. Note that the editor retains the sole right to decide whether or not the suggested reviewers are used.

Papers received by the Editorial Board are sent to referees. The suggestions/comments of the referees and Editorial Board are sent to the author(s) for further action. The revised article should be returned to the Editorial Board as soon as possible but in not more than 30 days.

\section{Preparation of manuscripts}

\section{Use of wordprocessing software}

It is important that the file be saved in the native format of the wordprocessor used. The text should be typed (1 $11 / 2$ spaced) on A4 paper with margins of $3.0 \mathrm{~cm}$ on each side in single-column format, font Times New Roman, Mac C Times, Macedonian Times and size 11, Keep the layout of the text as simple as possible. Most formatting codes will be removed and replaced on processing the article. In particular, do not use the wordprocessor's options to justify text or to hyphenate words. However, do use bold face, italics, subscripts, superscripts etc. When preparing tables, if you are using a table grid, use only one grid for each individual table and not a grid for each row. If no grid is used, use tabs, not spaces, to align columns. The electronic text should be prepared in a way very similar to that of conventional manuscripts. To avoid unnecessary errors you are strongly advised to use the "spell-check" and "grammarcheck" functions of your wordprocessor.

The pages in the article should be numbered.

Finally, please create PDF file before sending the article. After acceptance, you will be asked to supply the article as wordprocessing document (zip-file).

\section{Appendices}

If there is more than one appendix, they should be identified as A, B, etc. Formulae and equations in appendices should be given separate numbering: Eq. (A.1), Eq. (A.2), etc.; in a subsequent appendix, Eq. (B.1) and so on. Similarly for tables and figures: Table A.1; Fig. A.1, etc.

\section{Abbreviations}

Define abbreviations that are not standard in this field in a footnote to be placed on the first page of the article. Such abbreviations that are unavoidable in the abstract must be defined at their first mention there, as well as in the footnote. Ensure consistency of abbreviations throughout the article.

\section{Units}

Follow internationally accepted rules and conventions: use the international system of units (SI). If other units are mentioned, please give their equivalent in SI.

The names of substances should be in accordance with the IUPAC recommendations and rules or Chemical $A b$ stracts practice.

\section{Math formulae}

Present simple formulae in the line of normal text where possible and use the solidus (/) instead of a horizontal line for small fractional terms, e.g., X/Y. In principle, variables are to be presented in italics.

\section{Footnotes}

Footnotes should be used sparingly. Number them consecutively throughout the article, using superscript Arabic numbers. Many wordprocessors build footnotes into the text, and this feature may be used. Should this not be the case, indicate the position of footnotes in the text and present the footnotes themselves separately at the end of the article. Do not include footnotes in the Reference list.

\section{Table footnotes}

Indicate each footnote in a table with a superscript lowercase letter.

\section{Figures}

Figures (photographs, diagrams and sketches) and structural formulae should each be given on a separate sheet (the place to which they belong in the text should be indicated). The figures should be numbered in Arabic numerals (e.g. Fig. 1). Ensure that each illustration has a caption. Supply all captions separately, not attached to the figure. A caption should comprise a brief title (not on the figure itself) and a description of the illustration. Keep text in the illustrations themselves to a minimum but explain all symbols and abbreviations used.

Please submit the pictures in a black and white version.

Tables

The tables should be numbered in Arabic numerals (e.g. Table 1) and each should be given on a separate sheet (the place to which they belong in the text should be indicated). Number tables consecutively in accordance with their appearance in the text. Place footnotes to tables below the table body and indicate them with superscript lowercase letters. Be sparing in the use of tables and ensure that the data presented in the tables are not duplicated elsewhere in the article. 


\section{Article structure}

Manuscript should contain: title, abstract, key words, introduction, material and methods, results and discussion, conclusion, acknowledgment (if desired) references and summary.

\section{Subdivision}

Divide your article into clearly defined sections (Abstract, Introduction, Material and methods. etc.). Any section or subsection may be given a brief heading. Each heading should appear on its own separate line.

\section{Essential title page information}

Papers should be preceded by a title page comprising: the title, the complete name(s) of the authors, and the author's affiliations.

Title. Concise and informative. Avoid abbreviations and formulae where possible.

Author names and affiliations. Where the family name may be ambiguous (e.g., a double name), please indicate this clearly. Present the authors' affiliation addresses (where the actual work was done) below the names. Indicate all affiliations with a lower-case superscript arabic number immediately after the author's name and in front of the appropriate address. Provide the full postal address of each affiliation, including the country name of each author.

Corresponding author. Clearly indicate (with *) who will handle correspondence at all stages of refereeing and publication, also post-publication. Ensure that telephone and fax numbers (with country and area code) are provided in addition to the e-mail address and the complete postal address.

Each paper must begin with an Abstract which should not exceed more than 250 (original scientific and professional papers) or 100 (short communications) words. The abstract should state briefly the purpose of the research, the principal results and major conclusions. References should be avoided, but if essential, then cite the author(s) and year(s). Also, non-standard or uncommon abbreviations should be avoided, but if essential they must be defined at their first mention in the abstract itself. Immediately after the abstract, provide a list of 3 to 6 keywords arranged in the order according to their importance.

\section{Introduction}

State the objectives of the work and provide an adequate background, avoiding a detailed literature survey or a summary of the results.

\section{Material and methods}

Provide sufficient detail to allow the work to be reproduced. Methods already published should be indicated by a reference: only relevant modifications should be described. Manuscripts which are related to theoretical studies, instead of Material and methods, should contain a sub-heading and the Theoretical background where the necessary details for verifying the results obtained should be stated.

\section{Results}

Results should be clear and concise.

\section{Discussion}

This should explore the significance of the results of the work, not repeat them. A combined Results and Discussion section is often appropriate. Avoid extensive citations and discussion of published literature.

\section{Conclusions}

The main conclusions of the study may be presented in a short Conclusions section, which may stand alone or form a subsection of a Discussion or Results and Discussion section.

\section{Acknowledgements}

Collate acknowledgements in a separate section at the end of the article before the references and do not, therefore, include them on the title page, as a footnote to the title or otherwise. List here those individuals who provided help during the research (e.g., providing language help, writing assistance or proof reading the article, etc.).

\section{References}

\section{Citation in text}

Please ensure that every reference cited in the text is also present in the reference list (and vice versa). Any references cited in the abstract must be given in full. Unpublished results and personal communications are not recommended in the reference list, but may be mentioned in the text. If these references are included in the reference list they should follow the standard reference style of the journal and should include a substitution of the publication date with either "Unpublished results" or "Personal communication". Citation of a reference as "in press" implies that the item has been accepted for publication and a copy of the title page of the relevant article must be submitted.

\section{Web references}

As a minimum, the full URL should be given and the date when the reference was last accessed. Any further information, if known (DOI, author names, dates, reference to a source publication, etc.), should also be given. Web references can be listed separately (e.g., after the reference list) under a different heading if desired, or can be included in the reference list. 


\section{Reference style}

Text: All citations in the text should refer to:

1. Single author: the author's name (without initials, unless there is ambiguity) and the year of publication;

2. Two authors: both authors' names and the year of publication;

3. Three or more authors: first author's name followed by "et al." and the year of publication.

Citations may be made directly (or parenthetically). Groups of references should be listed first alphabetically, then chronologically.

Examples: "as demonstrated (Allan, 1996a, 1996b, 1999; Allan and Jones, 1995). Kramer et al. (2000) have recently shown...."

List: References should be arranged first alphabetically and then further sorted chronologically if necessary. More than one reference from the same author(s) in the same year must be identified by the letters "a", "b", "c", etc., placed after the year of publication.

\section{Examples:}

Reference to a journal publication:

Van der Geer, J., Hanraads, J.A.J., Lupton, R.A., 2000. The art of writing a scientific article. J. Sci. Commun. 163, 51-59.

Reference to a book:

Strunk Jr., W., White, E.B., 1979. The Elements of Style, third ed. Macmillan, New York.

Reference to a chapter in an edited book:

Mettam, G.R., Adams, L.B., 1999. How to prepare an electronic version of your article, in: Jones, B.S., Smith, R.Z. (Eds.), Introduction to the Electronic Age. E-Publishing Inc., New York, pp. 281-304.

Journal abbreviations source

Journal names should be abbreviated according to

Index Medicus journal abbreviations: http://www.nlm. nih.gov/tsd/serials/lji.html

List of serial title word abbreviations: http://www.issn. org/2-22661-LTWA-online.php;

CAS (Chemical Abstracts Service): http://www.cas. org/sent.html.

Manuscripts written in English should contain a Summary in Macedonian at the end of the paper. The summary should contain: title, author(s) full-name(s), surname(s), author's affiliations (institution and address), key words and abstract. Professional papers written in Macedonian should contain a summary in English in which the same data should be included.

\section{Submission checklist}

It is hoped that this list will be useful during the final checking of an article prior to sending it to the journal's
Editor for review. Please consult this Guide for Authors for further details of any item.

Ensure that the following items are present:

One Author designated as corresponding Author:

- E-mail address

- Telephone and fax numbers

- All necessary files have been uploaded

- Keywords

- All figure captions

- All tables (including title, description, footnotes)

- Further considerations: Manuscript has been "spellchecked" and "grammar-checked"

- $\quad$ References are in the correct format for this journal

- $\quad$ All references mentioned in the Reference list are cited in the text, and vice versa

- Permission has been obtained for use of copyrighted material from other sources (including the Web)

\section{After acceptance}

Proofs

One set of page proofs (as PDF files) will be sent by e-mail to the corresponding author. Please list the corrections and return them via e-mail. If, for any reason, this is not possible, then mark the corrections and any other comments on a printout of your proof and return by fax, or scan the pages and e-mail, or by post. Please use this proof only for checking the typesetting, editing, completeness and correctness of the text, tables and figures. Significant changes to the article as accepted for publication will not be accepted.

We will do everything possible to get your article published quickly and accurately. Therefore, it is important to ensure that all of your corrections are sent back to us in one communication: please check carefully before replying, as inclusion of any subsequent corrections cannot be guaranteed. Proofreading is solely your responsibility. Note that Macedonia Pharmaceutical Bulletin may proceed with the publication of your article if no response is received.

\section{Offprints}

The corresponding author, at no cost, will be provided with a PDF file of the article by e-mail. The PDF file is a watermarked version of the published article and includes a cover sheet with the journal cover image.

Additional paper offprints can also be ordered for an extra charge. 